\title{
Variation in Botryosphaeriaceae from Eucalyptus plantations in YunNan Province in southwestern China across a climatic gradient
}

\author{
Guoqing Li $\mathrm{Li}^{1,2,3}$, Bernard Slippers ${ }^{2}$, Michael J. Wingfield ${ }^{2}$ and Shuaifei Chen ${ }^{1,3^{*}}$ (D)
}

\begin{abstract}
The Botryosphaeriaceae accommodates many important pathogens of woody plants, including Eucalyptus. Recently, Botryosphaeriaceae were isolated from diseased plant parts from surveys of Eucalyptus plantations in the YunNan Province, China. The aims of this study were to identify these Botryosphaeriaceae isolates and to evaluate their pathogenicity to Eucalyptus. A total of 166 isolates of Botryosphaeriaceae were obtained from six regions in the YunNan Province, of which 76 were from Eucalyptus urophylla $\times$ E. grandis hybrids, 49 from E. globulus trees, and 41 isolates were from other unknown Eucalyptus species or hybrids. Isolates were identified by comparing DNA sequences of the internal transcribed spacer ribosomal RNA locus (ITS), partial translation elongation factor 1-alpha (tef1), $\beta$-tubulin 2 (tub2) and DNA-directed RNA polymerase II subunit (rpb2) genes, and combined with their morphological characteristics. Eleven species were identified, including Botryosphaeria fusispora, B. wangensis, Lasiodiplodia pseudotheobromae, Neofusicoccum kwambonambiense, N. parvum, and six novel species described as B. puerensis, $N$. dianense, N. magniconidium, N. ningerense, $N$. parviconidium and $N$. yunnanense. The dominant species across the regions were N. yunnanense, N. parvum and B. wangensis, representing 31.3, 25.3 and $19.9 \%$ of the total isolates, respectively. Species diversity and composition changed across the different climatic zones, despite their relatively close geographic proximity and the fact that some of the species have a global distribution. All the Botryosphaeriaceae species were pathogenic to one-year-old plants of an E. urophylla $\times E$. grandis clone and $E$. globulus seed-derived plants, but showed significant inter- and intra-species variation in aggressiveness amongst isolates. The study provides a foundation for monitoring and management of Botryosphaeriaceae through selection and breeding of Eucalyptus in the YunNan Province of southwestern China.
\end{abstract}

KEYWORDS: Botryosphaeria, Lasiodiplodia, Neofusicoccum, Pathogenicity, Phylogeny, Taxonomy

\section{INTRODUCTION}

Eucalyptus species have been widely planted in many countries of the world for wood and fibre needs, mostly due to their rapid growth and adaptability to a variety of ecological conditions (Coppen 2002). In China, with

\footnotetext{
* Correspondence: shuaifei.chen@gmail.com

${ }^{1}$ State Key Laboratory of Tree Genetics and Breeding (SKLTGB), Chinese

Academy of Forestry (CAF), Haidian District, Beijing 100091, China

${ }^{3}$ China Eucalypt Research Centre (CERC), Chinese Academy of Forestry (CAF),

ZhanJiang 524022, GuangDong Province, China

Full list of author information is available at the end of the article
}

more than 4.5 million hectares of Eucalyptus planted, an important area for Eucalyptus plantation establishment is the YunNan Province (Xie et al. 2017). This province includes seven climatic zones due to variation in altitude. These include a cold highland zone (T1), central temperate zone (T2), southern temperate zone (T3), northern sub-tropical zone (T4), central sub-tropical zone (T5), southern sub-tropical zone (T6) and tropical zone (T7) (Ye 2017). Most Eucalyptus have been planted in the sub-tropical and tropical (T4-T7), central and

(c) The Author(s). 2020 Open Access This article is licensed under a Creative Commons Attribution 4.0 International License, which permits use, sharing, adaptation, distribution and reproduction in any medium or format, as long as you give

appropriate credit to the original author(s) and the source, provide a link to the Creative Commons licence, and indicate if changes were made. The images or other third party material in this article are included in the article's Creative Commons licence, unless indicated otherwise in a credit line to the material. If material is not included in the article's Creative Commons licence and your intended use is not permitted by statutory regulation or exceeds the permitted use, you will need to obtain permission directly from the copyright holder. To view a copy of this licence, visit http://creativecommons.org/licenses/by/4.0/ 
southern parts of the YunNan Province. The Eucalyptus species planted include large areas of E. urophylla $\times E$. grandis hybrids and E. globulus, and smaller areas of $E$. nitens and E. smithii (Qi 2002).

In recent years, Eucalyptus plantations in China have faced significant health threats from different pathogens, including species in the Botryosphaeriaceae (Chen et al. 2011), Cryphonectriaceae (Chen et al. 2010; Wang et al. 2018) and Teratosphaeriaceae (Burgess et al. 2006a), as well as Botrytis (Liu et al. 2016), Calonectria (Lombard et al. 2010; Li et al. 2017), Ceratocystis (Chen et al. 2013), Quambalaria (Zhou et al. 2007; Chen et al. 2017) and Ralstonia (Carstensen et al. 2017). Of these, Botryosphaeriaceae are amongst the most widespread and common associated with Eucalyptus plantations in southern China (Chen et al. 2011; Li et al. 2018).

Diseases associated with Botryosphaeriaceae have been reported on a variety of woody plants globally (Slippers and Wingfield 2007; Dissanayake et al. 2016; Mehl et al. 2017; Slippers et al. 2017). They usually occur when plants are subjected to environmental stresses, including drought, frost, physical damage and biological stress (Old et al. 2003; Slippers and Wingfield 2007; Manawasinghe et al. 2016). Typical symptoms associated with Botryosphaeriaceae infections include die-back, canker, shoot blight, and fruit rot (Slippers and Wingfield 2007; Slippers et al. 2017; Billones-Baaijens and Savocchia 2019). On Eucalyptus in China, the Botryosphaeriaceae has been associated with stem cankers as well as shoot and twig blights.

The taxonomic status of Botryosphaeriaceae has been substantially revised in recent years and now includes 23 genera and at least 200 species known from culture (Liu et al. 2012; Phillips et al. 2013; Dissanayake et al. 2016; Slippers et al. 2017; Yang et al. 2017; Jayawardena et al. 2019a, 2019b). These species include many cryptic taxa and require DNA sequence-based identification, often considering sequence data from multiple loci. Recent studies on the Botryosphaeriaceae from Eucalyptus in China that have been based on DNA sequence data have identified twelve species. These include Botryosphaeria dothidea, B. fabicerciana, B. fusispora, B. pseudoramosa, B. qingyuanensis, Lasiodiplodia brasiliense, L. pseudotheobromae, L. theobromae, Neofusicoccum microconidium, $N$. parvum, $N$. ribis sensu lato and $N$. sinoeucalypti (Yu et al. 2009; Chen et al. 2011; Li et al. $2015,2018)$. These studies have, however, not included thorough sampling from Eucalyptus in the YunNan Province.

During disease surveys in Eucalyptus plantations in the YunNan Province in 2014, typical disease symptoms linked to the Botryosphaeriaceae were observed. The aims of this study were to (1) identify the species of Botryosphaeriaceae isolated from diseased Eucalyptus trees in YunNan Province based on phylogenetic inference combined with morphological characteristics, (2) determine their geographic distribution in different regions of this province, and (3) evaluate their pathogenicity on one-year-old plants of an $E$. urophylla $\times E$. grandis hybrid clone and E. globulus seed-derived plants.

\section{MATERIALS AND METHODS}

\section{Sample collection and fungal isolation}

Field surveys of Eucalyptus plantations were conducted in YunNan Province of southwestern China during 2014. A large area of these Eucalyptus plantations was severely damaged by disease with symptoms typical of the Botryosphaeriaceae. These symptoms included die-back, leaf and shoot blight, stem and branch canker, and they resulted in tree death in some plantations (Fig. 1).

Stems, branches and twigs from Eucalyptus trees showing typical symptoms of Botryosphaeriaceae infection were collected. Botryosphaeriaceae isolates were obtained as described in Li et al. (2018). All cultures were deposited in the Culture Collection (CSF) of the China Eucalypt Research Centre (CERC), Chinese Academy of Forestry (CAF), ZhanJiang, GuangDong Province, China. Duplicate cultures were deposited in the culture collection (CMW) of the Forestry and Agricultural Biotechnology Institute (FABI), University of Pretoria, Pretoria, South Africa, and representative cultures were deposited in the China General Microbiological Culture Collection Center (CGMCC), Beijing, China. The dried specimens were deposited in the mycological fungarium of the Institute of Microbiology, Chinese Academy of Sciences (HMAS), Beijing, China.

\section{DNA extraction, PCR amplification and sequencing}

Total DNA of each isolate was extracted from the mycelium of 7-day-old cultures using the CTAB method as described in van Burik et al. (1998). RNA from each DNA sample was removed by adding $2 \mathrm{~mL}$ RNase A (10 $\mathrm{mg} / \mathrm{mL}$ ) and incubating at $37^{\circ} \mathrm{C}$ for $1 \mathrm{~h}$. Quality and quantity of the DNA samples were determined using a NanoDrop 2000 Spectrometer (Thermo Fisher Scientific Inc. Waltham, MA, USA), and each DNA sample was diluted to approximately $100 \mathrm{ng} / \mathrm{uL}$ with DNase/RNasefree $\mathrm{ddH}_{2} \mathrm{O}$ (Sangon Biotech Co., Ltd., Shanghai, China) for PCR amplification. Three to four loci were amplified, including the internal transcribed spacer (ITS), a part of the translation elongation factor 1-alpha (tef1), a part of the $\beta$-tubulin 2 (tub2) and a part of DNA directed RNA polymerase II subunit ( $r p b 2)$. Details regarding primers, PCR reactions and cycling conditions were as described by Li et al. (2018). Primers were synthesised and PCR products were sequenced by the Beijing Genomics Institute (BGI), GuangZhou, GuangDong Province, China. 

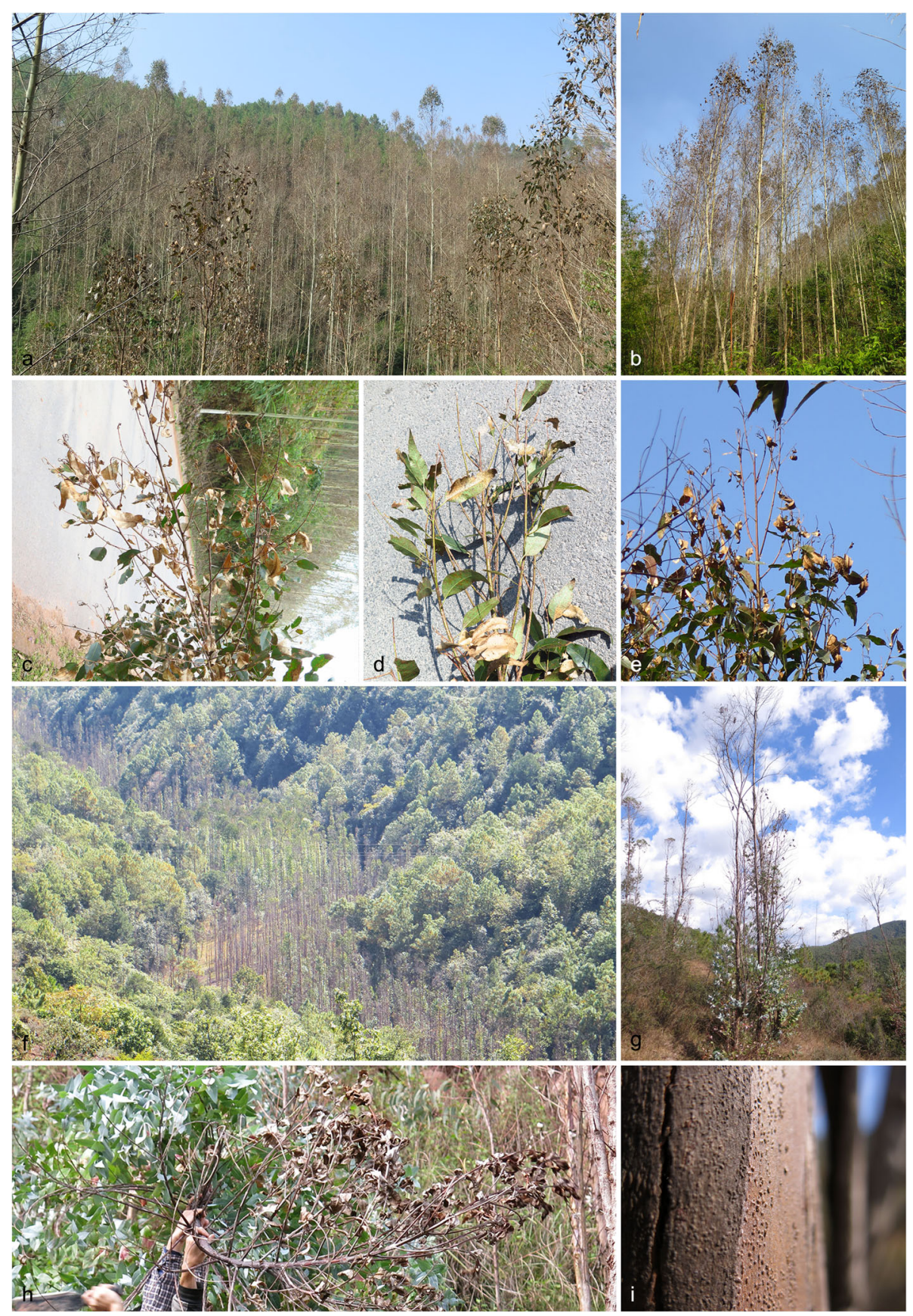

Fig. 1 Disease symptoms on Eucalyptus trees associate with Botryosphaeriaceae in YunNan Province. a, b. die-back of E. urophylla $\times$ E. grandis hybrids; c-e. branch and twig blight of E. urophylla $\times E$. grandis hybrids. $\mathbf{f}-\mathbf{h}$. die-back of E. globulus; i. fruiting structures on an E. globulus stem

Sequences obtained in this study were all deposited in GenBank (http://www.ncbi.nlm.nih.gov) (Table 1).

\section{Phylogenetic analyses}

Sequences of the ITS, tef1 and tub2 regions for all isolates obtained in this study were generated for species identification. Based on these sequences, the initial genotype of each isolate was determined. Representative isolates based on initial genotype characterisation, host and location for each species were selected for sequencing of the $r p b 2$ locus. The final genotypes of the selected isolates were thus determined based on sequence data from four loci. Preliminary identification in this study was performed using Standard Nucleotide BLAST (https://blast.ncbi.nlm.nih.gov/Blast.cgi), and available sequences of all species in related genera containing ex- 


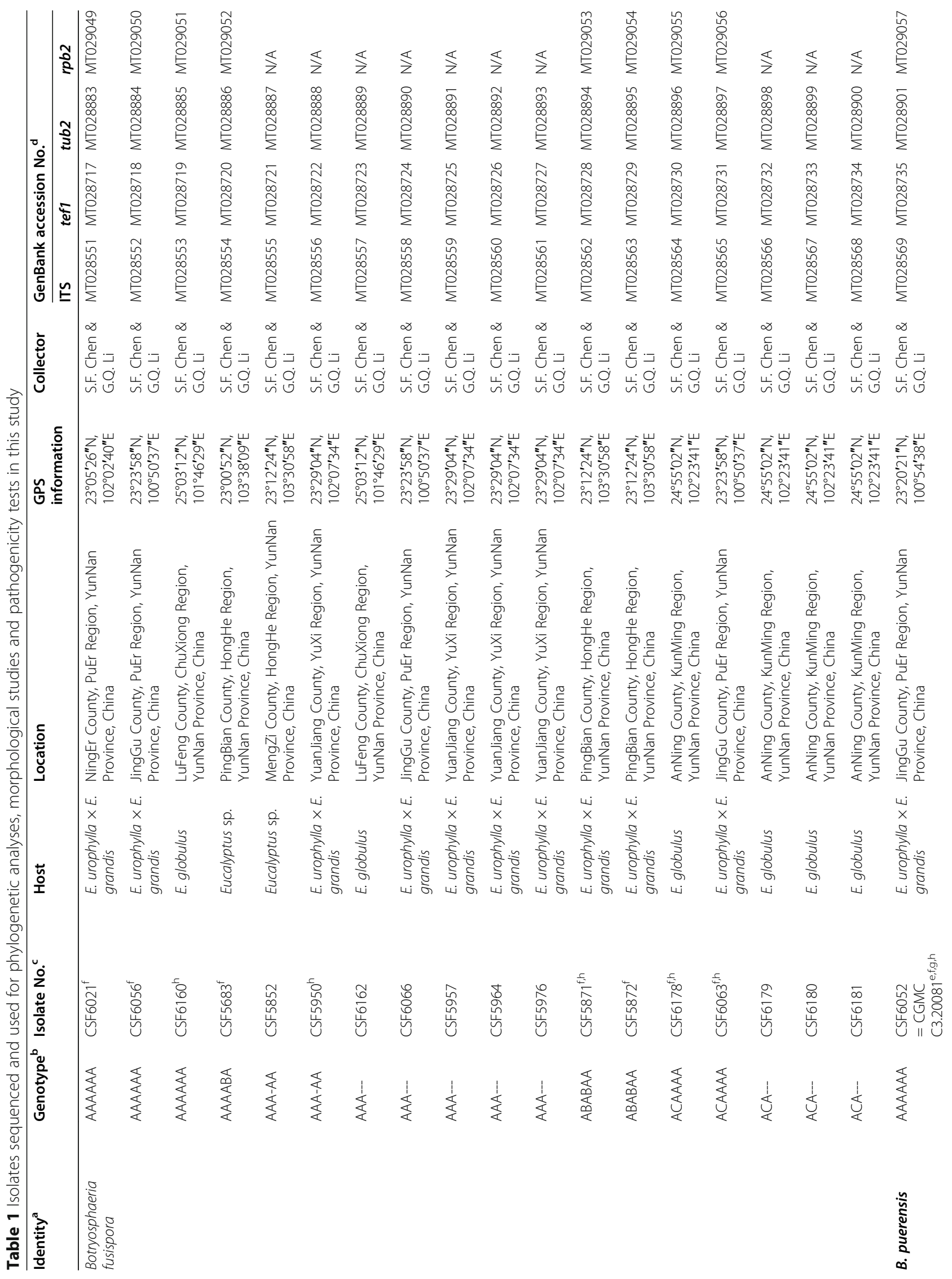




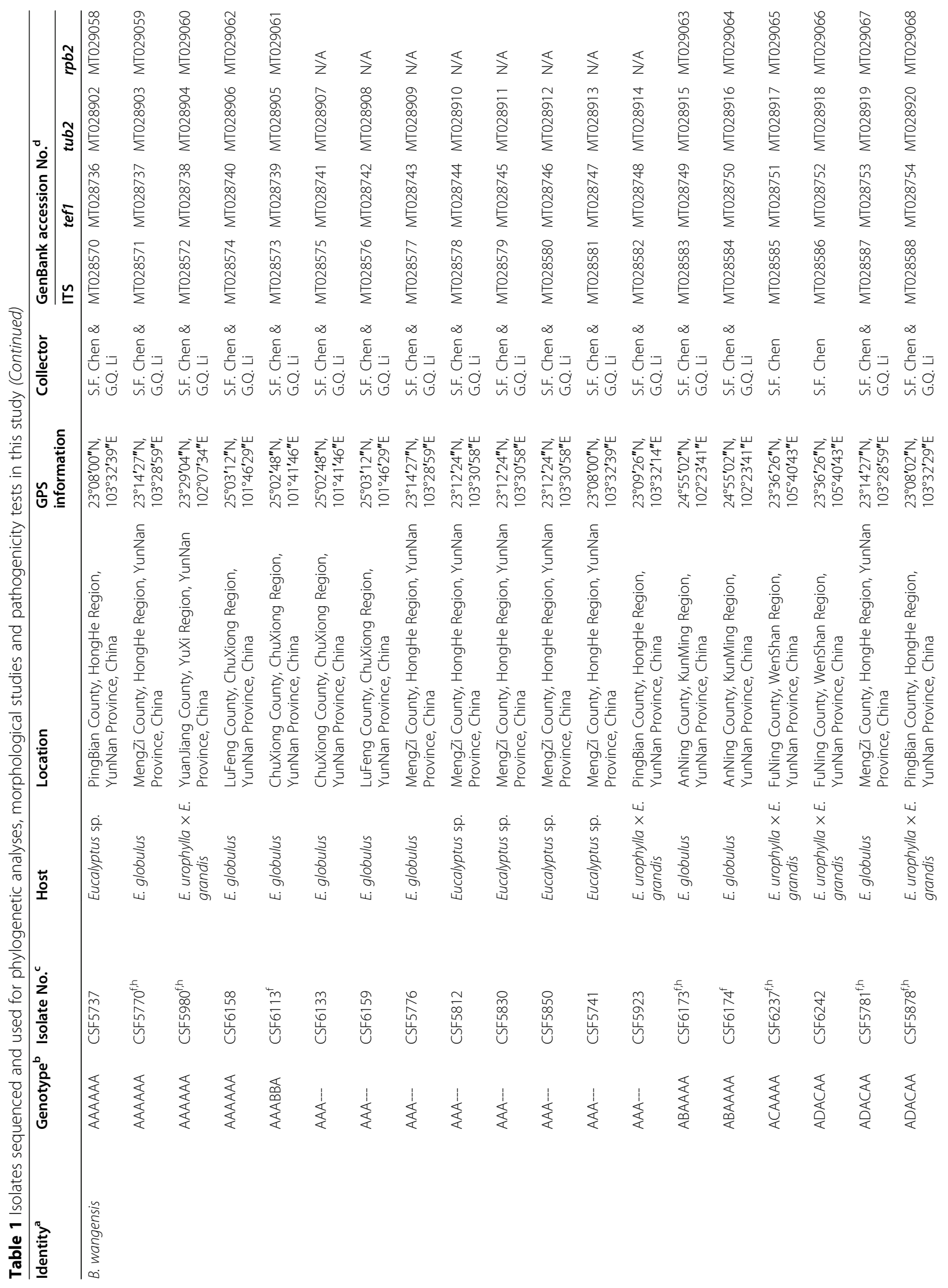




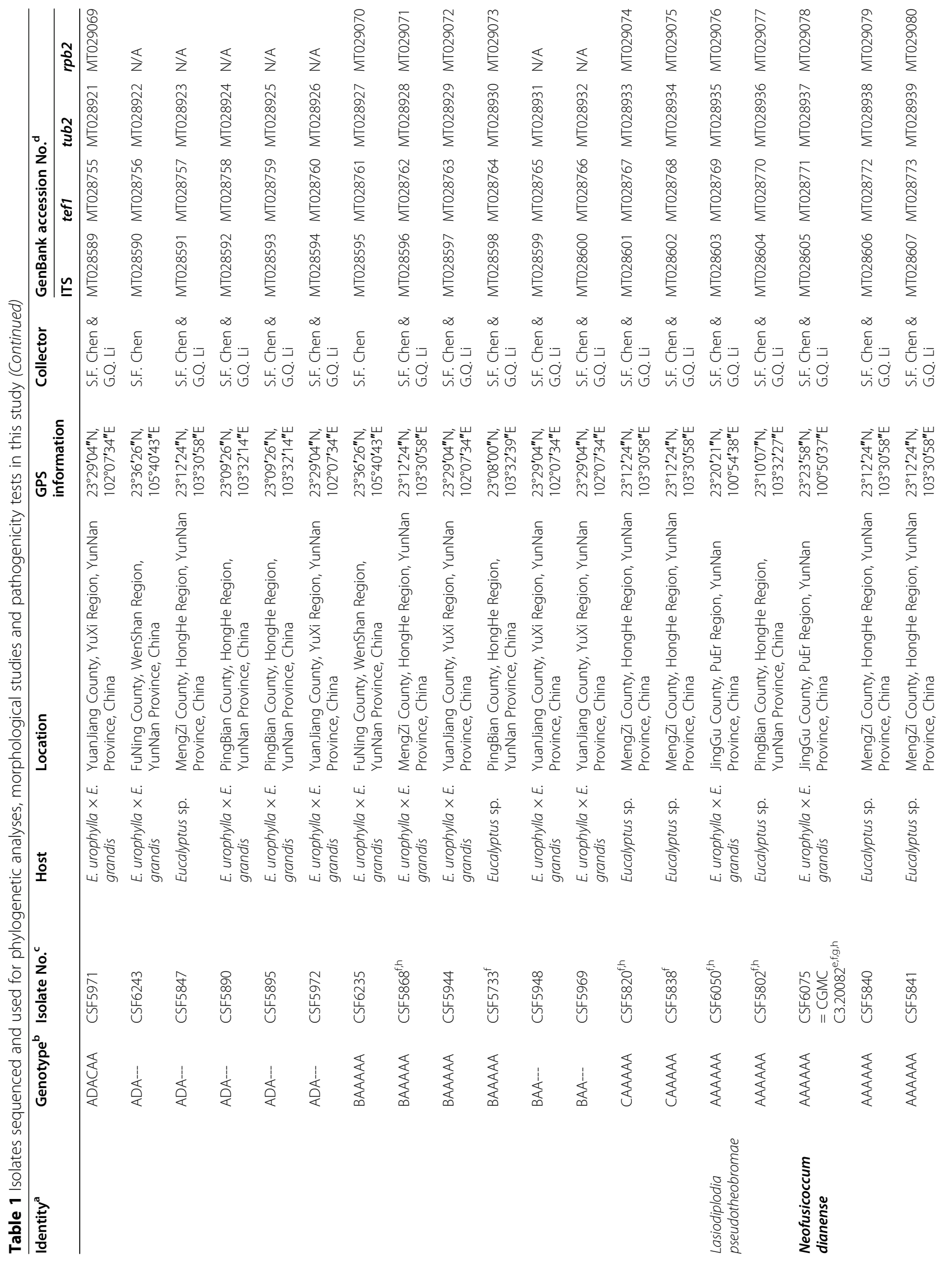




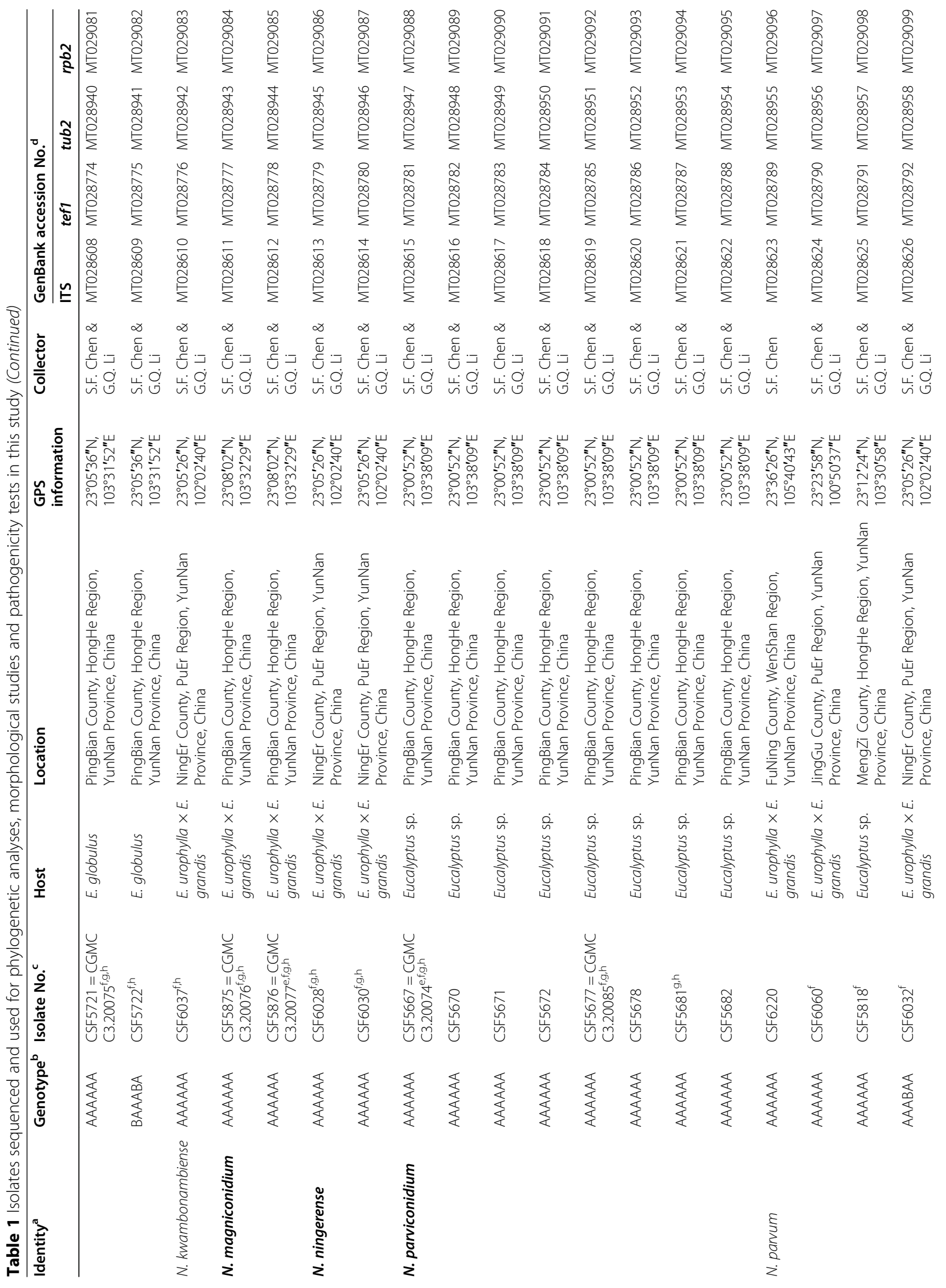




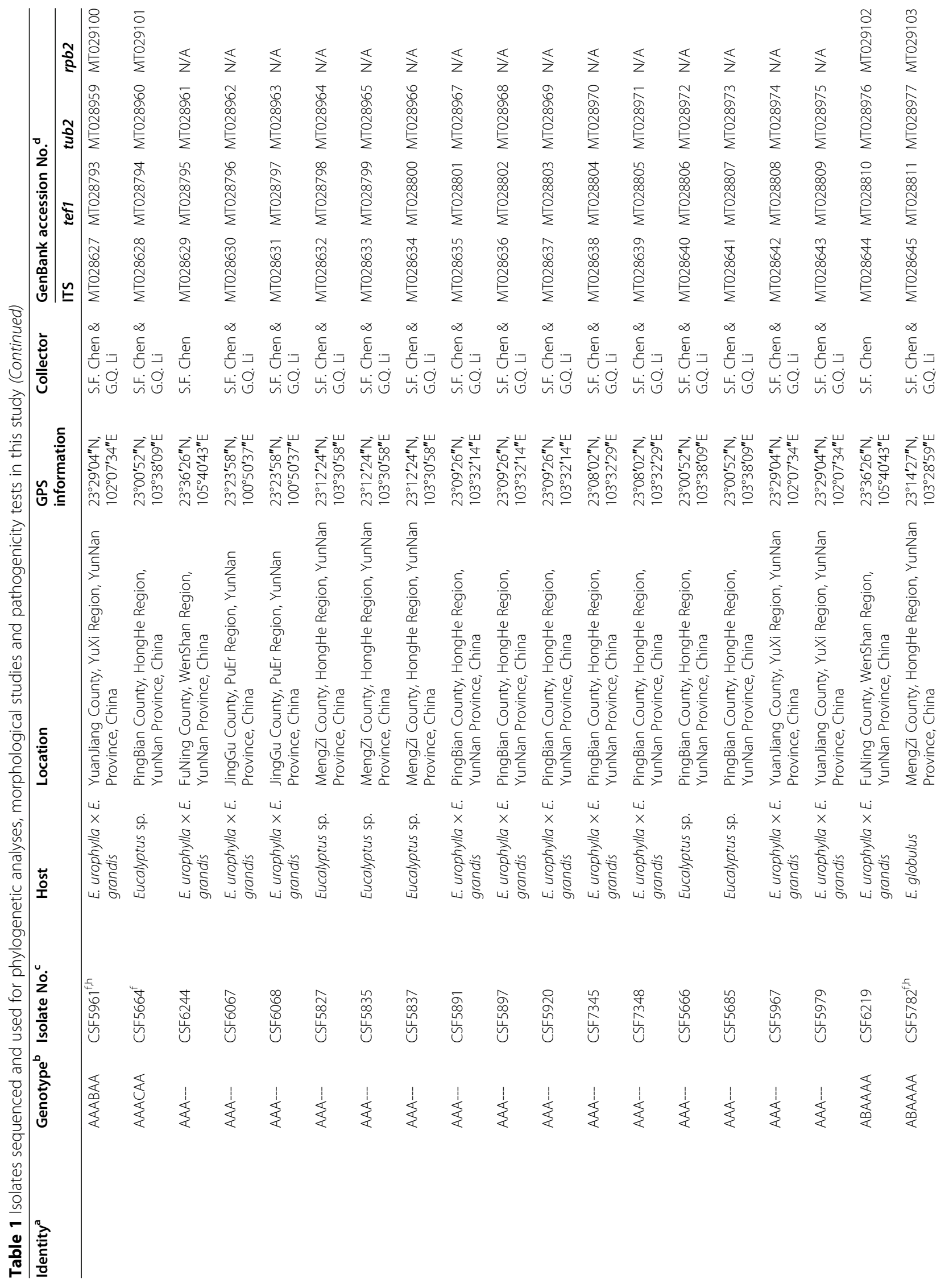




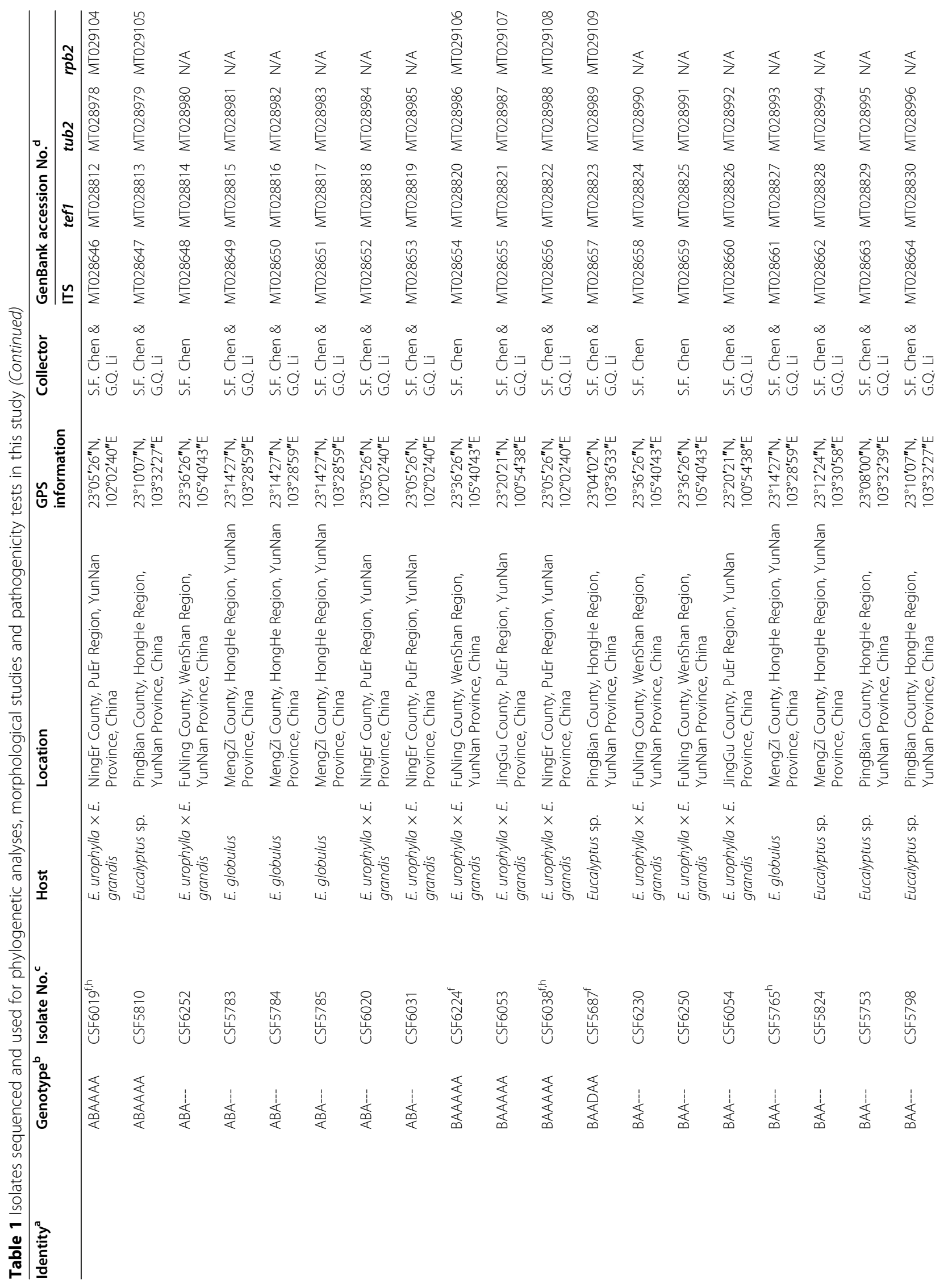




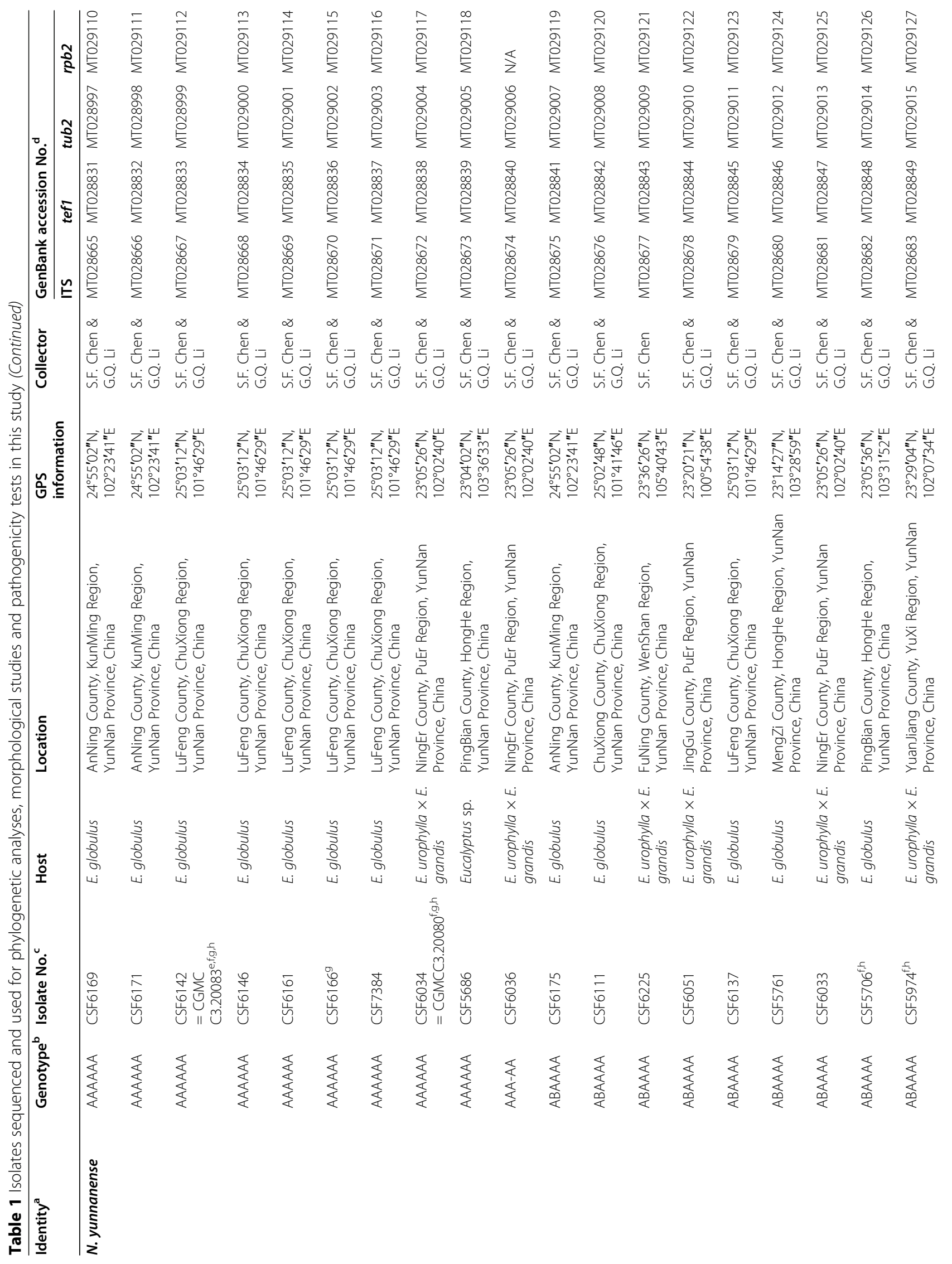




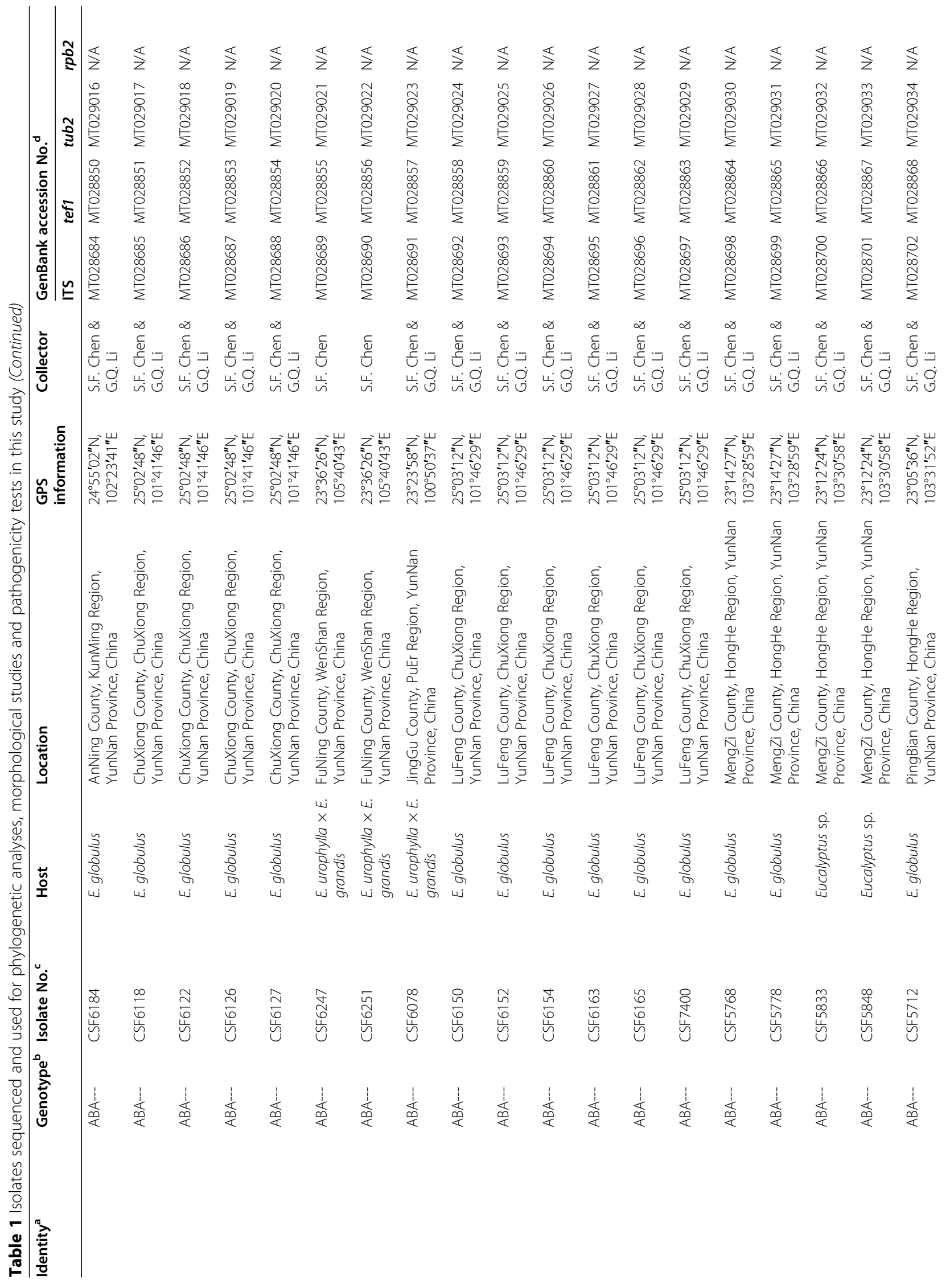




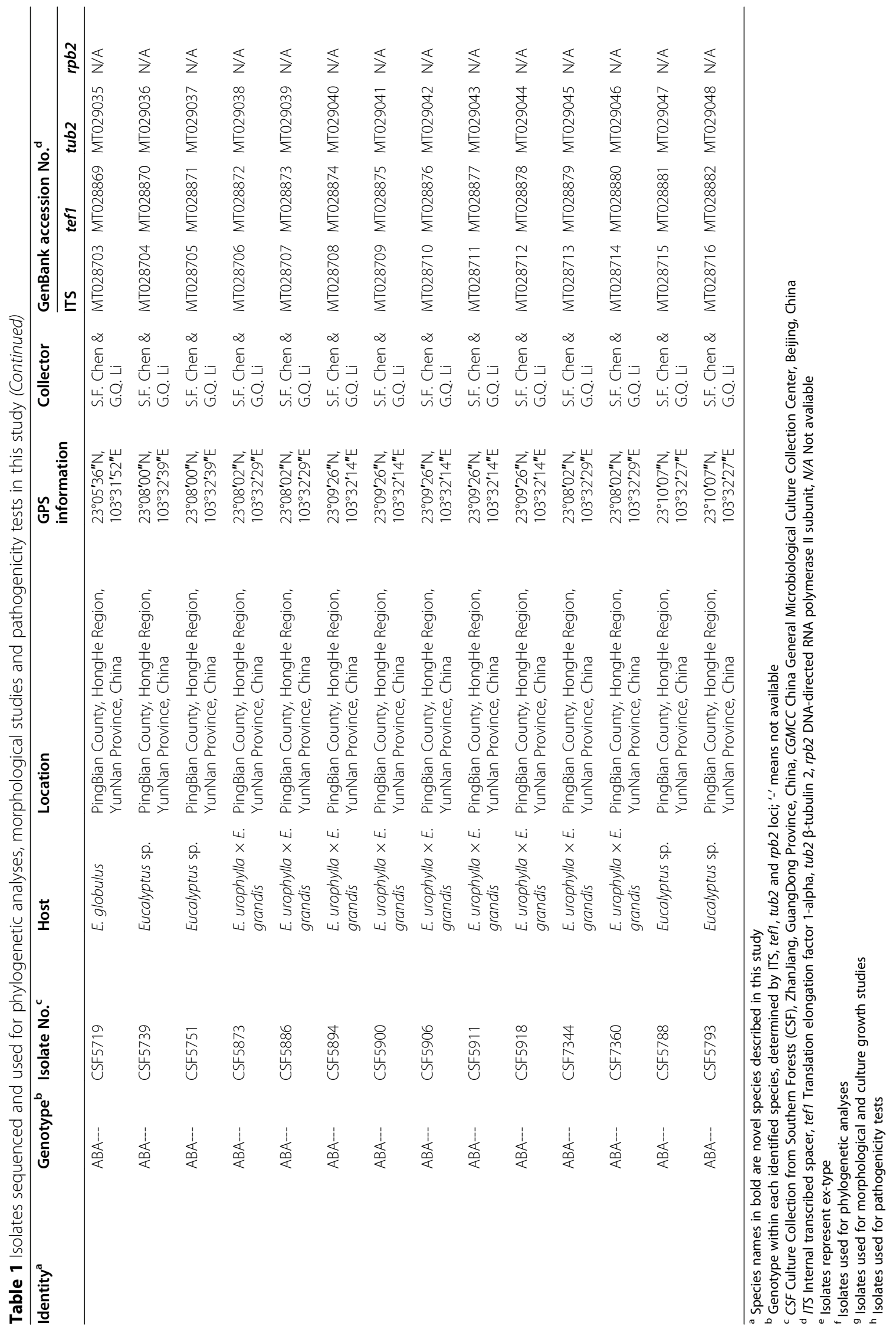




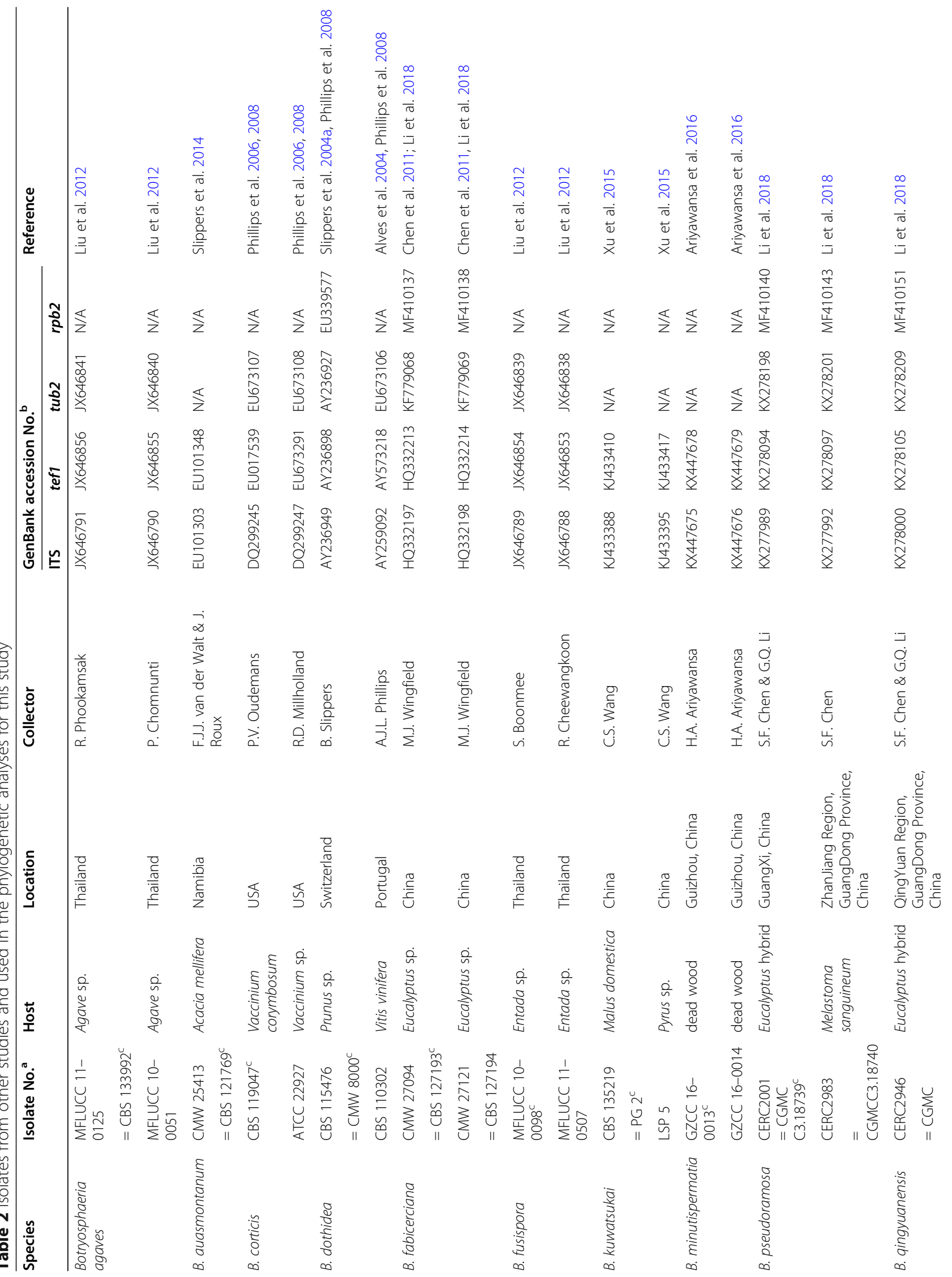




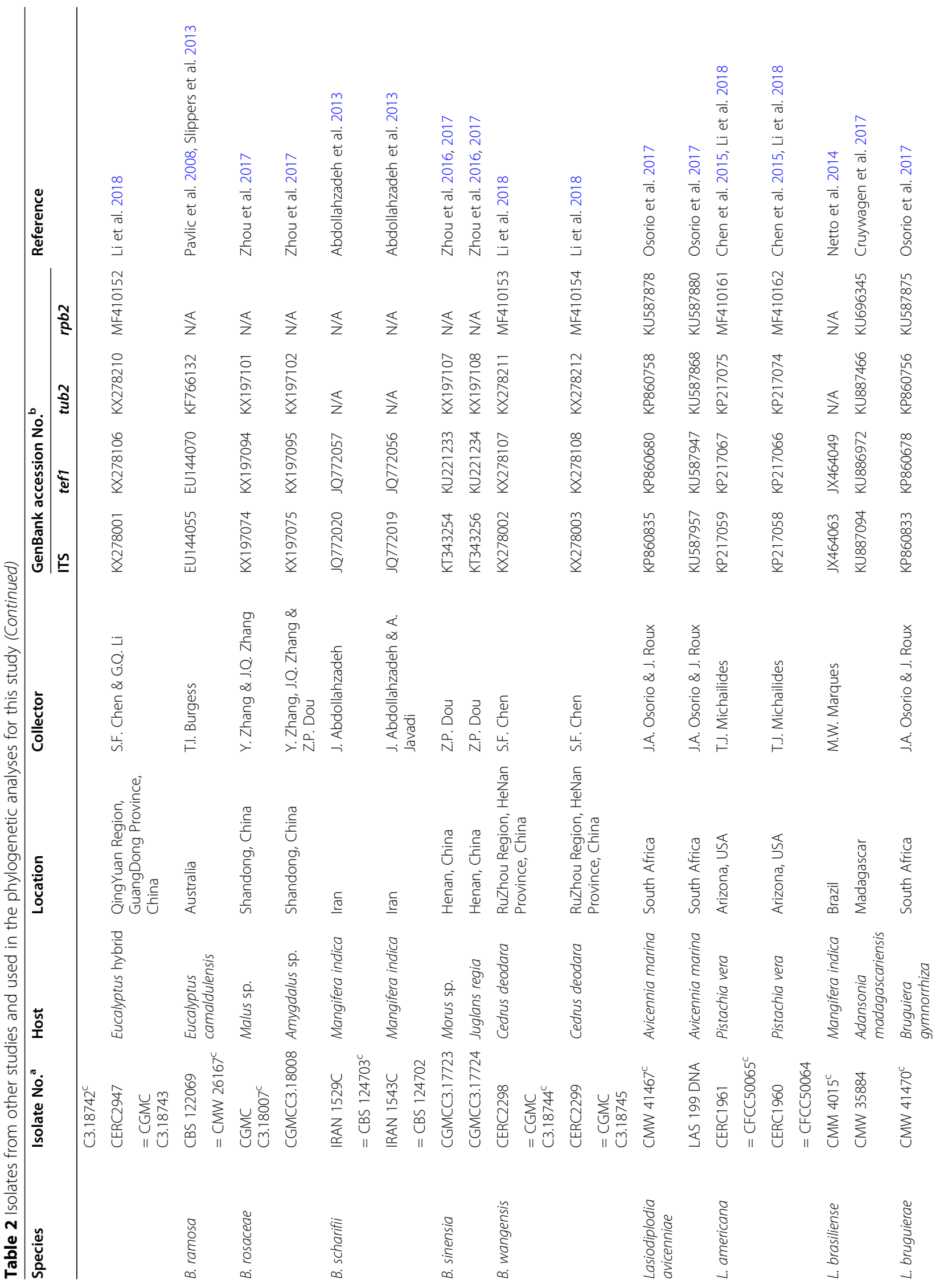




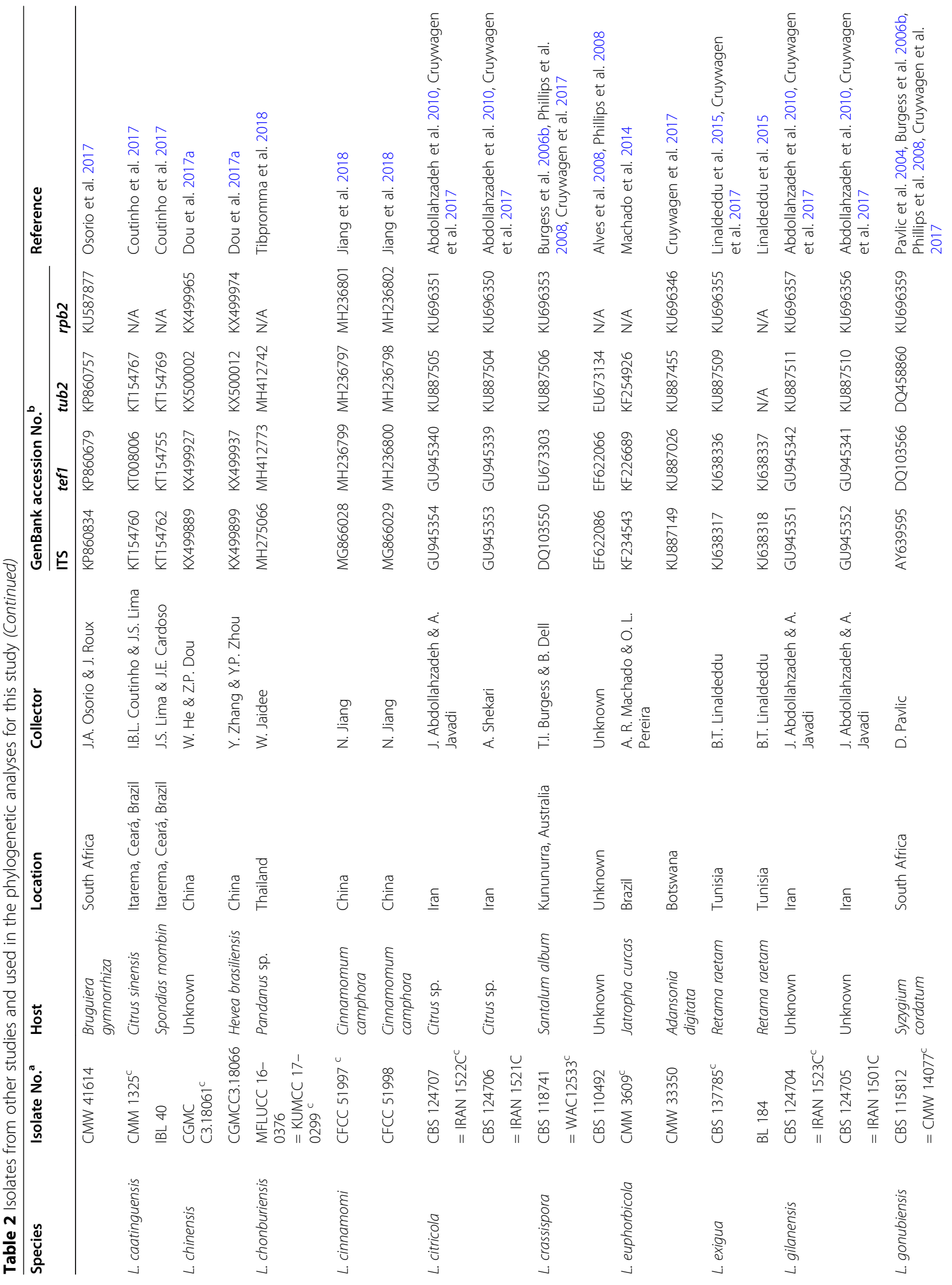




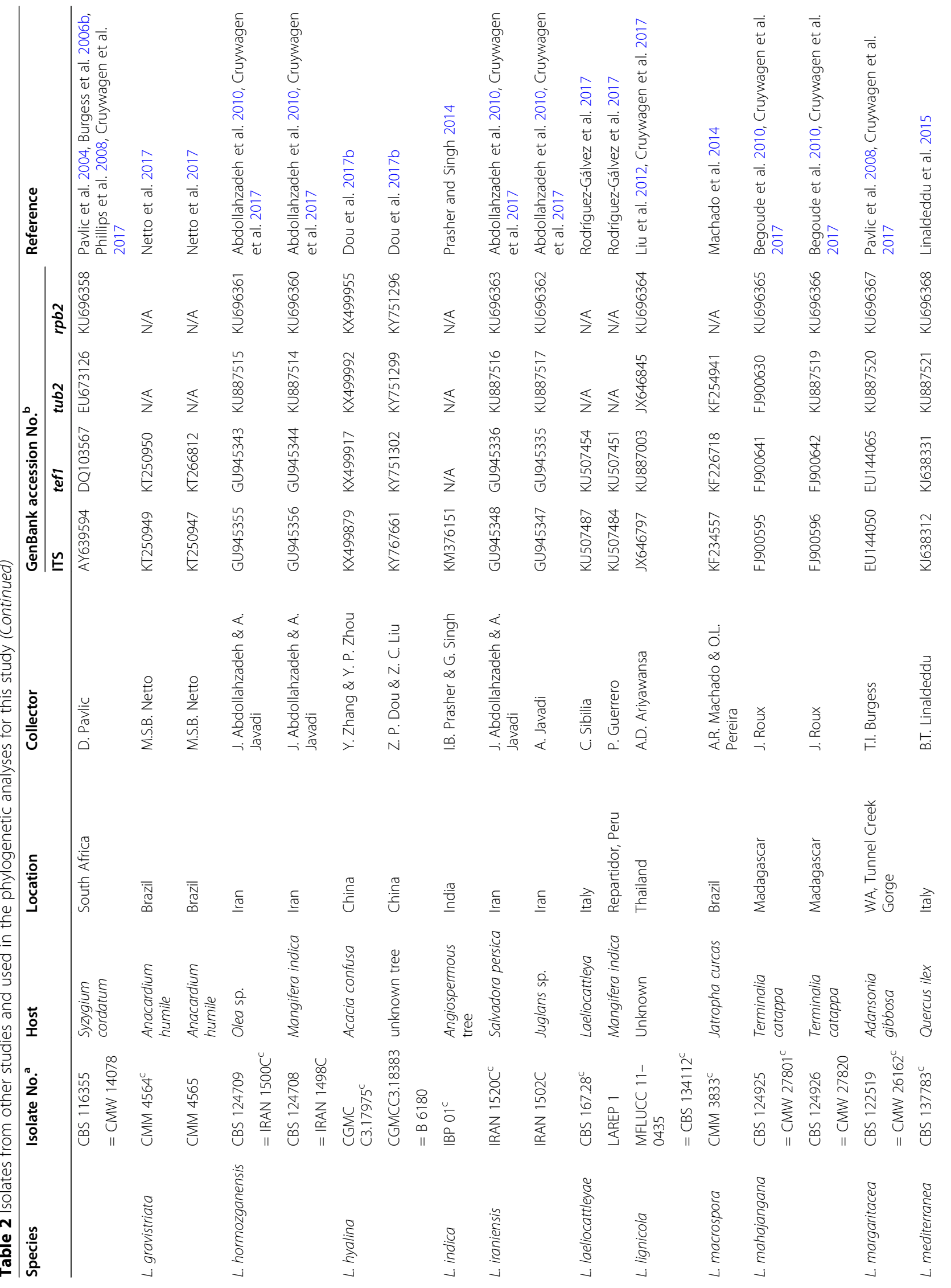




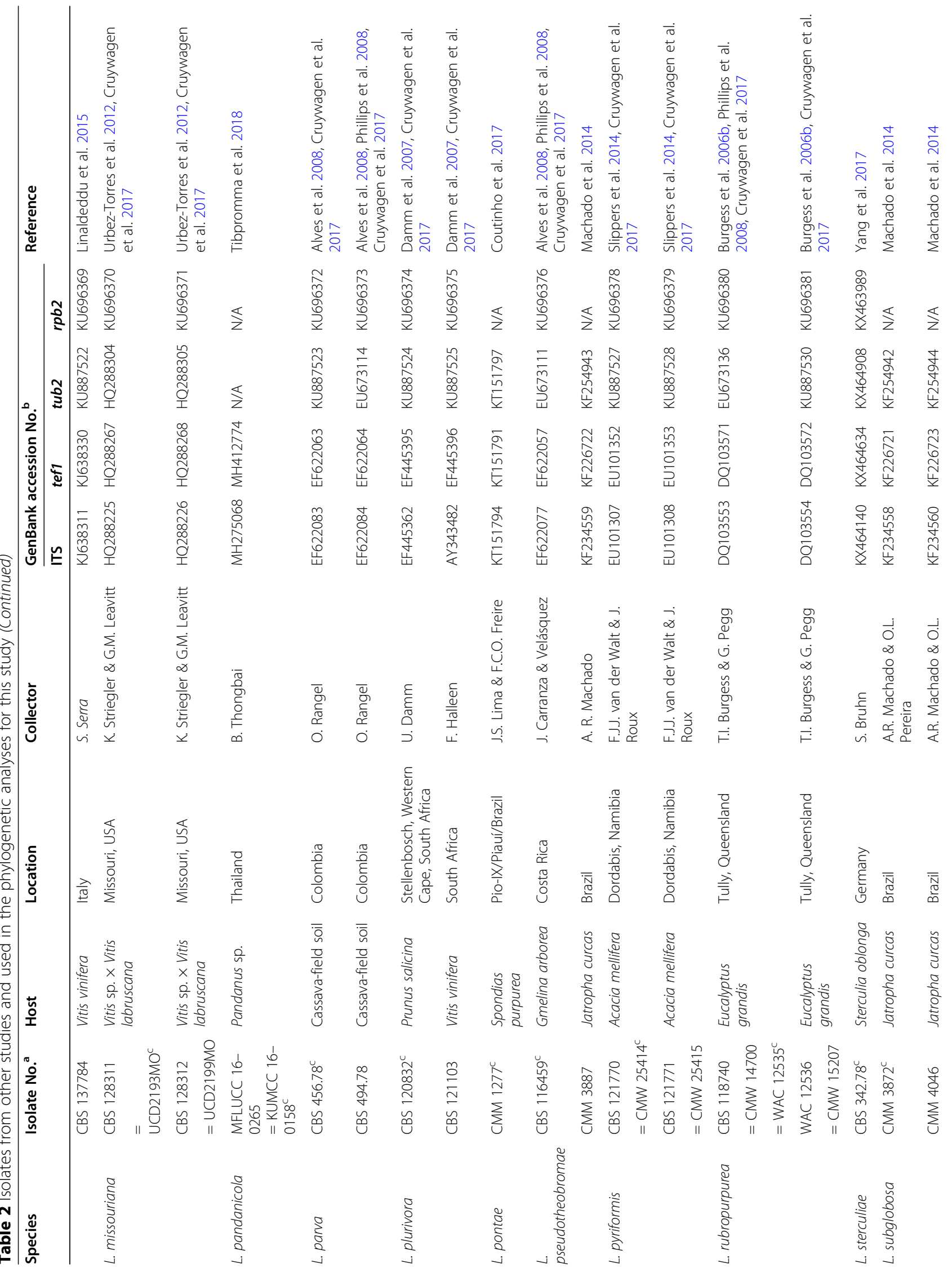




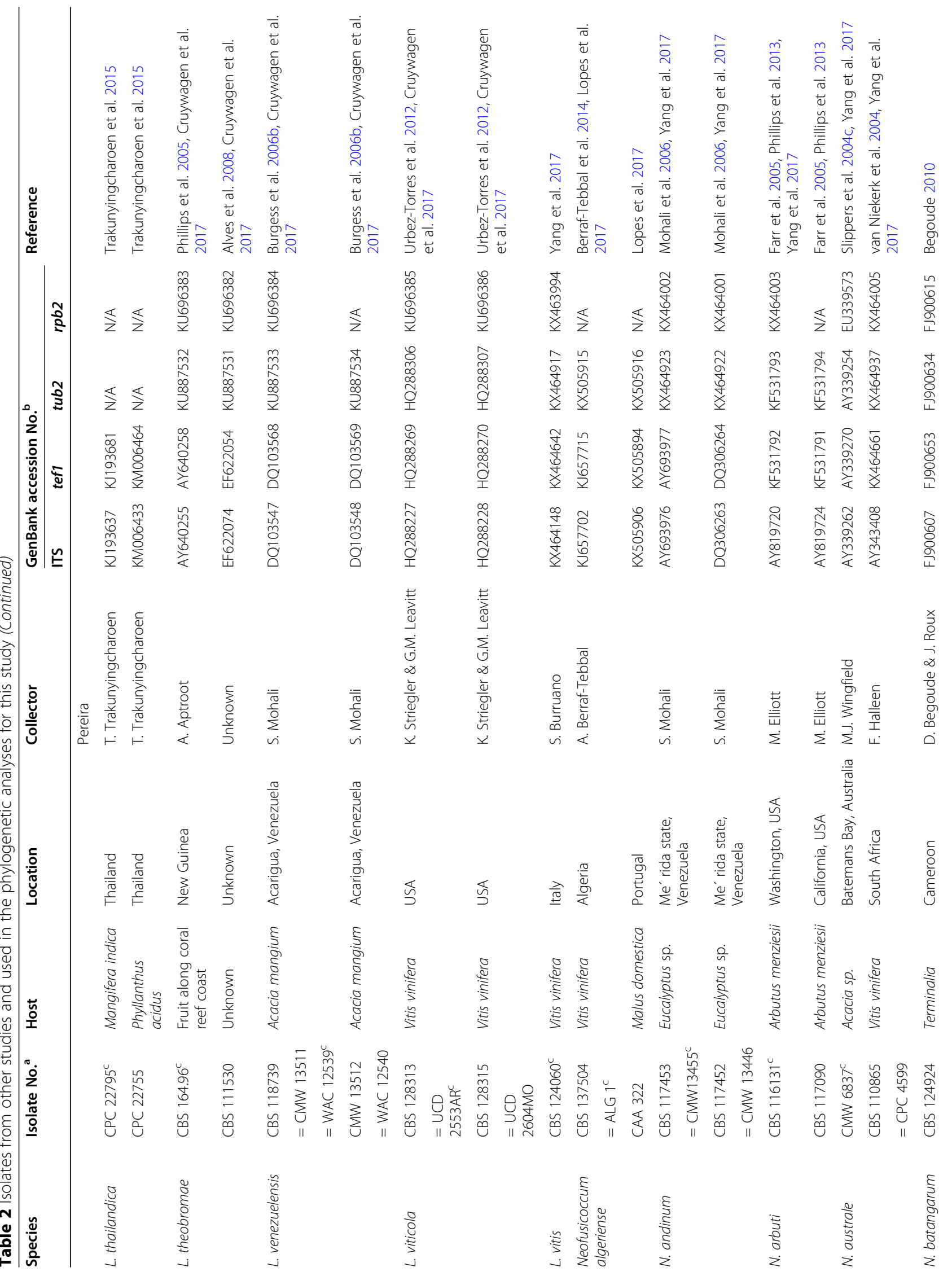




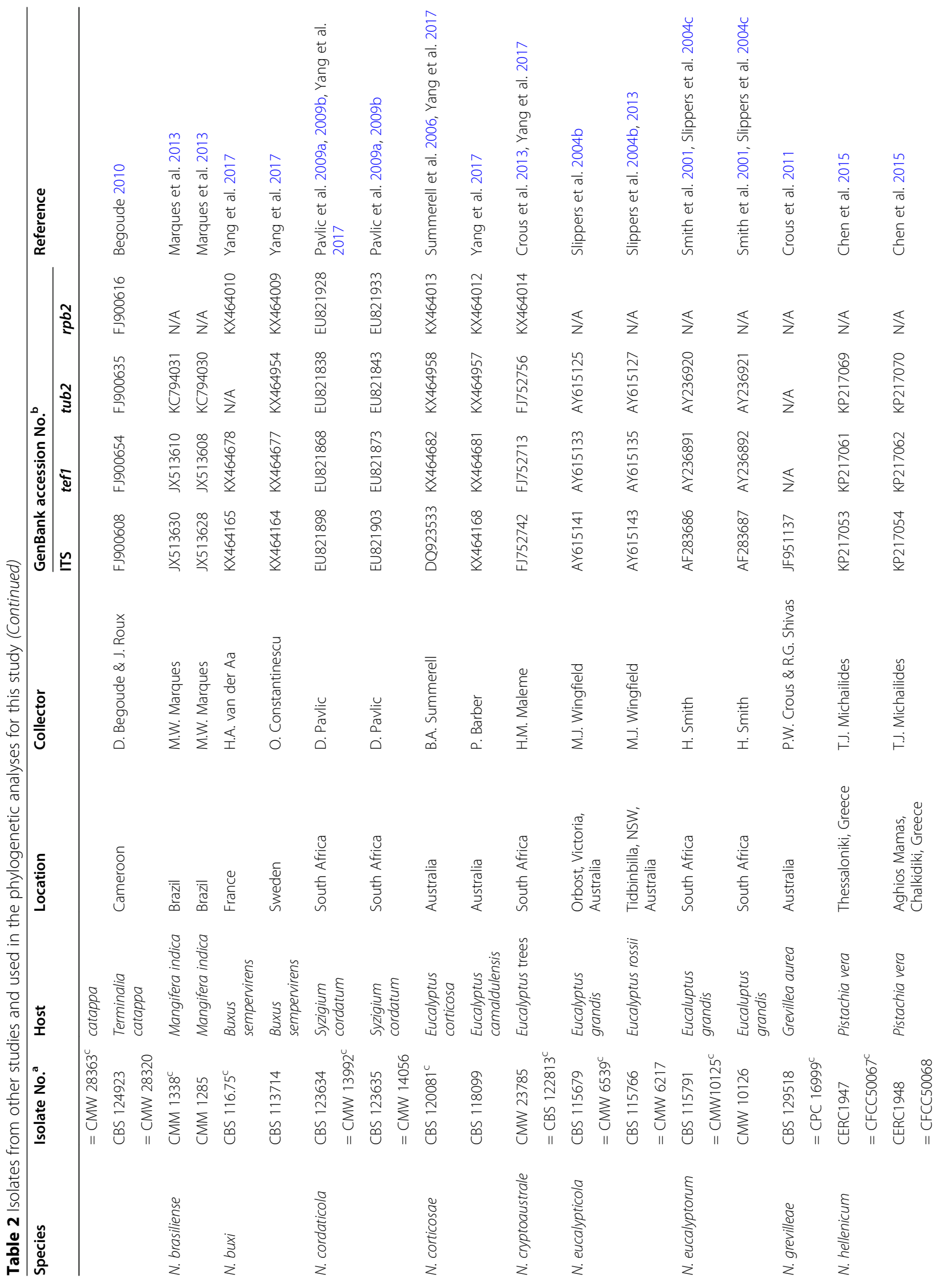




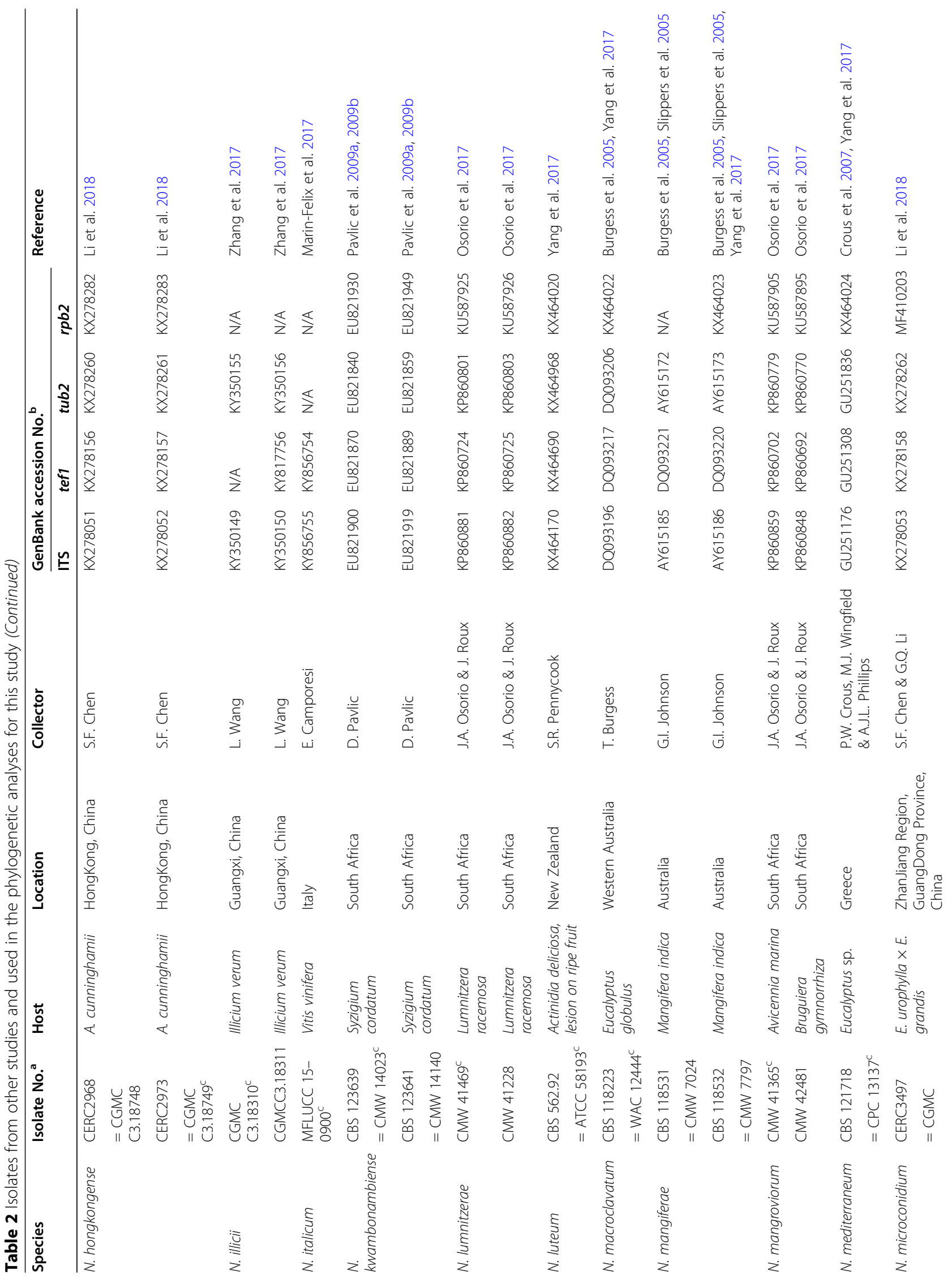




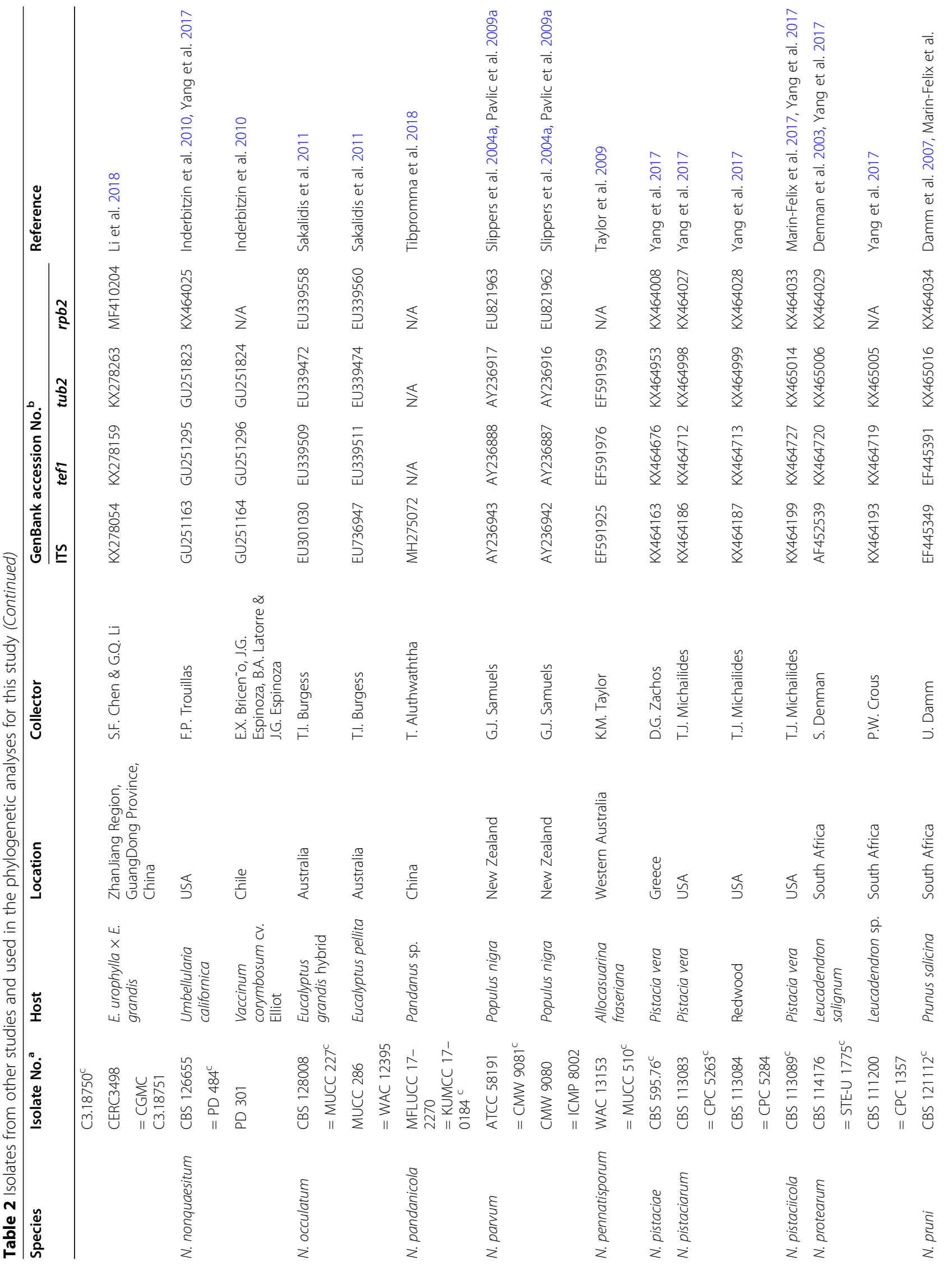




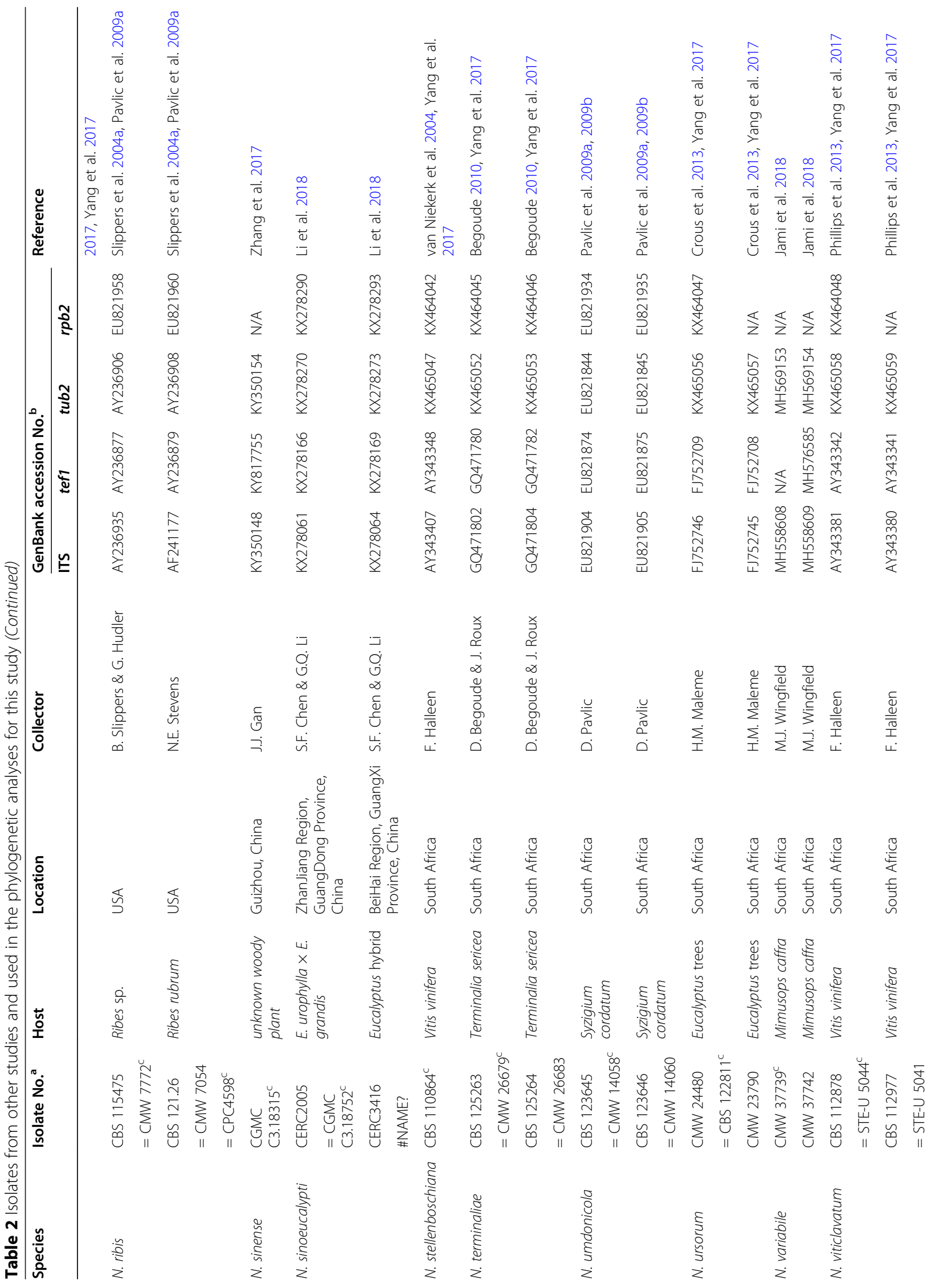




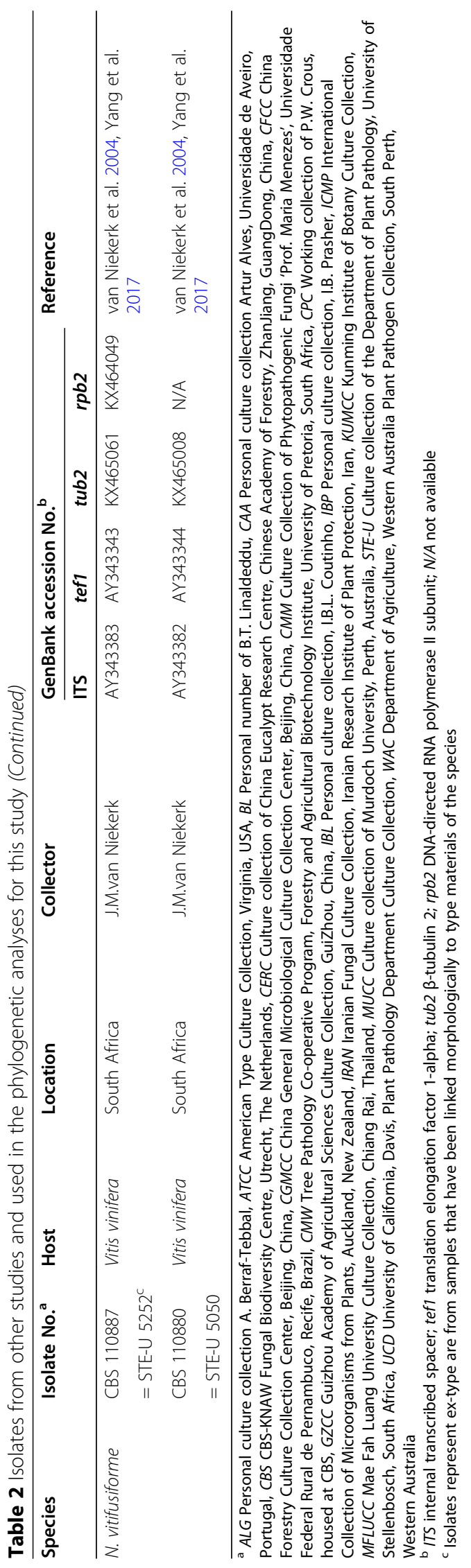


type isolates were downloaded from the NCBI for phylogenetic analyses. The sequences were aligned using the online version of MAFFT v.7 (http://mafft.cbrc.jp/alignment/server/) (Katoh and Standley 2013), with the iterative refinement method (FFT-NS-i setting). The alignments were checked manually and edited in MEGA v.6.0.5 (Tamura et al. 2013). Sequence alignments were deposited in TreeBASE.

Maximum likelihood (ML) analyses with 1000 bootstrap replicates were conducted using PhyML v.3.0 (Guindon et al. 2010). The best-fit model of nucleotide substitution for each dataset was determined using jModelTest v.2.1.5 (Darriba et al. 2012). Maximum parsimony (MP) trees were generated in PAUP v.1.0b10 (Swofford 2002), using the heuristic search function with tree bisection and reconstruction (TBR) as branch swapping algorithms and 1000 random addition replicates. Gaps were treated as a fifth character and the characters were unordered and given equal weight. MAXTREES were set to 5000, branches of zero length were collapsed and all multiple, equally parsimonious trees were saved. Tree length (TL), consistency index (CI), retention index $(\mathrm{RI})$, rescaled consistency index (RC) and homoplasy index (HI) were calculated. Bootstrap support values were evaluated using 1000 bootstrap replicates (Hillis and Bull 1993). The phylogenetic analyses for Botryosphaeria were rooted using N. parvum (ATCC 58191), and phylogenetic analyses for Lasiodiplodia and Neofusicoccum were rooted using Botryosphaeria dothidea (CBS 115476) (Table 2).

The criterion applied to determine species boundaries was based on phylogenetic analyses and sequences comparisons. Thus, species were considered unique when isolate(s) formed a distinct lineage that differentiated them from other isolates in at least two of the three or four individual loci (ITS, tef1 and tub2 for Botryosphaeria; or ITS, tef1, tub2 and rpb2 for Lasiodiplodia and Neofusicoccum). Furthermore, where these groupings were not contradicted at the other loci, and where they had fixed Single Nucleotide Polymorphisms (SNPs) that differentiated them from their phylogenetically closest species.

\section{Morphology}

For the description of putatively novel species, microscopic features and colony characteristics were examined. More than one Botryosphaeriaceae species was frequently isolated from the pycnidia on the same Eucalyptus branch, and most of the isolates were obtained from diseased tissues, which were free of fruiting structures. Consequently, isolates were grown on Petri dishes containing $2 \%$ water agar (WA) with several doubleautoclaved pine needles on their surface (Smith et al. 1996). These plates were incubated at room temperature under near-ultraviolet light for 4-6 wk. to induce sporulation. Relevant morphological characteristics were examined and recorded using a Zeiss Axio Imager A1 microscope and a Zeiss AxioCam MRc digital camera with Zeiss Axio Vision v.4.8 software (Carl Zeiss Ltd., Oberkochen, Germany). The lengths and widths of 50 conidia per isolate were measured. These are presented as average (mean), standard deviation (SD), minimum $(\mathrm{min})$ and maximum $(\max )$ of the conidial measurements are presented as (min-) (mean-SD)-(mean + $\mathrm{SD})(-\max )$. The ratio of average length to average width $(\mathrm{L} / \mathrm{W})$ for each species was calculated. Morphological descriptions were deposited in MycoBank (www.mycobank.org).

To determine the optimum temperatures for growth of the novel species, a 5-mm-diam plug of agar was cut from the actively growing margin of a 7-day-old colony and placed at the centre of a 90-mm-diam Petri dish containing 2\% MEA. Five replicate plates were used for each isolate at each temperature and these were incubated in the dark at temperatures ranging from 5 to $40^{\circ} \mathrm{C}$ at $5{ }^{\circ} \mathrm{C}$ intervals. Two diameter measurements, perpendicular to each other, were recorded daily until the fastest growing culture reached the edge of the Petri dish. The average colony diameter for each of the eight temperatures was calculated. Colony colour was determined from 7-day-old cultures grown on 2\% MEA at $25^{\circ} \mathrm{C}$ using the colour charts of Rayner (1970).

\section{Pathogenicity tests}

To determine the relative pathogenicity of the species identified in this study, inoculation trials were conducted under natural conditions using potted-trees of an E. urophylla $\times E$. grandis hybrid clone and E. globulus seedderived plants at the South China Experiment Nursery (SCEN), located in ZhanJiang, GuangDong, China. Oneyear-old healthy plants of the $E$. urophylla $\times E$. grandis clone and E. globulus seed-derived plants, approximately $170 \mathrm{~cm}$ high and $2 \mathrm{~cm}$ diameter at the root collar, were utilised. For each plant, a 5-mm-diam wound was made on the stem (approximately $30 \mathrm{~cm}$ above the root collar) using a cork borer to remove the bark and expose the cambium. Seven-day-old cultures of representative isolates, representing different species of Botryosphaeriaceae incubated at $25^{\circ} \mathrm{C}$ in the dark, were prepared and mycelial plugs were cut with a 5-mm-diam cork borer from the actively growing margins of these cultures. Mycelial plugs were placed into wounds with the mycelium facing the xylem. The wounds were sealed with masking tape immediately after inoculation to protect them from contamination and desiccation.

Ten trees of each Eucalyptus species were inoculated for each isolate. Negative controls were conducted on ten trees of the E. urophylla $\times E$. grandis hybrid clone or 
E. globulus seed-derived plants with clean 2\% MEA plugs. After one month, lesion lengths were measured and the average lesion length for the control treatments was subtracted from the average length for the fungustreated plants. This measurement reflected the result of the fungal inoculation without including the wound response due to physical damage in the controls. Reisolations were made from the inoculated plants to fulfil Koch's postulates. General Linear Model (GLM) Univariate Analysis (two-way ANOVA) and one-way ANOVA were used to determine the differences in aggressiveness among isolates utilising the programmes SPSS v.20 (IBM Corp 2011) and SAS v.9.3 (SAS Institute Inc 2011), respectively for the two analyses.

\section{RESULTS}

\section{Sample collection and fungal isolation}

For each sampled tree, between one and five isolates of Botryosphaeriaceae were obtained. A total of 166 Botryosphaeriaceae isolates from 89 Eucalyptus trees were collected from the six regions (ChuXiong, HongHe, KunMing, PuEr, WenShan and YuXi) sampled (Table 1, Fig. 11). Of these, 76 isolates $(45.8 \%)$ were from $E$. urophylla $\times E$. grandis, including 23 isolates from 11 trees in the HongHe Region, 25 isolates were from 12 trees in the PuEr Region, 14 isolates from six trees in the WenShan Region and 14 isolates were from nine trees in the YuXi Region. Forty-nine isolates (29.5\%) were from $E$. globulus, including 23 isolates from 18 trees in the ChuXiong Region, 16 isolates from eight trees in the HongHe Region and 10 isolates from four trees in the KunMing Region. Forty-one isolates (24.7\%) were from 21 other unknown Eucalyptus species or hybrids in the HongHe Region.

\section{Phylogenetic analyses}

The ITS, tef1 and tub2 loci were amplified for all the 166 isolates (Table 1). Subsequently, 82 representative isolates were selected based on these sequences so as to include all the genotypes revealed by these three loci, as well as all the sampling regions and Eucalyptus genotypes. The $r p b 2$ locus was then also sequenced for these 82 isolates (Table 1). The sequence fragments were approximately $520 \mathrm{bp}$ for the ITS, $280 \mathrm{bp}$ for the tef1, 430 bp for the $t u b 2$ and $610 \mathrm{bp}$ for the rpb2. The genotype of each isolate was determined based on the four loci, and one or two isolates were then selected for phylogenetic analyses, depending on the number of isolates available for each genotype (Table 1).

Based on the BLAST search against the nucleotide database on the NCBI website, three genera (Botryosphaeria, Lasiodiplodia and Neofusicoccum) in the Botryosphaeriaceae were identified. Sequences of ex-type isolates for all species in these genera were downloaded and used in the phylogenetic analyses. The aligned sequences for each locus (ITS, tef1, tub2 and $r p b 2$ ), as well as the combined sequences of three or four loci (Botryosphaeria: ITS, tef1, tub2; Lasiodiplodia and Neofusicoccum: ITS, tef1, tub2, rpb2) were deposited in TreeBASE (No. S25832). Statistical values for all datasets for ML and MP analyses are presented in Table 3. Isolates obtained in this study were divided into 11 groups (A to K) based on phylogenetic analyses. Single nucleotide polymorphism (SNP) analyses for the novel taxa emerging from this study and their closest sister taxa are presented in Table 4.

\section{Species in Botryosphaeria}

Sequence data were not available for rpb2 for ex-type isolates of various Botryosphaeria species (Table 2). The Botryosphaeria isolates clustered in three groups (Group A, Group B and Group C) based on tef1, tub2, rpb2 and combined ITS/tef1/tub2 analyses, and two groups based on ITS analyses, including Group A and where Group B clustered with Group C (Fig. 2).

Isolates in Group A clustered with B. wangensis and $B$. minutispermatia based on phylogenetic analyses of ITS dataset (Fig. 2a). In the tef1 tree, they clustered with or were closely related to $B$. wangensis, $B$. auasmontanum, B. dothidea, B. minutispermatia and B. sinensia (Fig. $2 \mathrm{~b})$. In the tub2 tree, they clustered with $B$. dothidea, $B$. fabicerciana, B. qingyuanensis, B. rosaceae and B. sinensia, and were closely related to $B$. wangensis (Fig. 2c). In the $r p b 2$ tree, they clustered with or were closely related to $B$. wangensis and $B$. dothidea (Fig. $2 \mathrm{~d}$ ). In the combined ITS/tef1/tub2 tree, these isolates were closely related to B. wangensis (Fig. 2e). Some isolates formed an independent clade based on one of the four individual loci (isolates CSF6173 and CSF6174 in the tef1 tree, isolate CSF6237 in the tef1 tree, and isolate CSF6113 in the rpb2 tree) (Fig. 2b-d); isolates CSF5781 and CSF5878 formed an independent clade based on two loci (tef1 and $r p b 2$ trees) (Fig. 2b, d), while they only had three fixed SNPs (one in each of ITS, tef1 and tub2 loci, respectively) different to the phylogenetically closest species, $B$. wangensis. Based on the phylogenetic analyses for the different datasets and fixed SNPs difference, isolates in Group A were identified as B. wangensis.

Isolate CSF6052 in Group B clustered with B. fabicerciana, B. fusispora, B. kuwatsukai and B. rosaceae based on the ITS tree (Fig. 2a). This isolate formed an independent clade that was distinct from all known species based on the tef1, tub2, rpb2 and the combined ITS/ tef1/tub2 trees (Fig. 2b-e). There were also 23 fixed SNPs different to its phylogenetically closest species, $B$. qingyuanensis. Consequently, isolate CSF6052 was recognised as an undescribed species. 
Table 3 Statistical values of datasets for maximum parsimony and maximum likelihood analyses

\begin{tabular}{|c|c|c|c|c|c|c|c|c|c|c|c|}
\hline \multirow{3}{*}{$\begin{array}{l}\text { Genus } \\
\text { Botryosphaeria }\end{array}$} & \multirow{3}{*}{$\begin{array}{l}\text { Dataset } \\
\text { ITS }\end{array}$} & \multicolumn{10}{|c|}{ Maximum likelihood } \\
\hline & & \multirow{2}{*}{$\begin{array}{l}\text { Subst. } \\
\text { model }^{a} \\
T r N+1\end{array}$} & \multirow{2}{*}{$\begin{array}{l}\text { NST }^{\mathrm{b}} \\
6\end{array}$} & \multicolumn{5}{|c|}{ Rate matrix } & \multirow{2}{*}{$\begin{array}{l}\text { p-inv } \\
0.7570\end{array}$} & \multirow{2}{*}{$\begin{array}{l}\text { Gamma } \\
-\end{array}$} & \multirow{2}{*}{$\begin{array}{l}\text { Rates } \\
\text { Equal }\end{array}$} \\
\hline & & & & 1.0000 & 1.5461 & 1.0000 & 1.0000 & 5.4052 & & & \\
\hline & tefi & TVM + I & 6 & 1.2703 & 4.1281 & 1.8345 & 0.0377 & 4.1281 & 0.5680 & - & Equal \\
\hline & tub2 & $\mathrm{TIM} 2+\mathrm{G}$ & 6 & 0.2584 & 4.1669 & 0.2584 & 1.0000 & 8.5072 & - & 0.0280 & Gamma \\
\hline & $r p b 2$ & TPM3uf + I & 6 & 2872.6267 & $37,884.9415$ & 1.0000 & 2872.6267 & $37,884.9415$ & 0.7290 & - & Equal \\
\hline & ITS/tef1/tub2 & $\operatorname{TrN}+1$ & 6 & 1.0000 & 3.6483 & 1.0000 & 1.0000 & 6.4337 & 0.7430 & - & Equal \\
\hline \multirow[t]{5}{*}{ Lasiodiplodia } & ITS & $\begin{array}{l}\text { TPM1 uf }+ \\
I+G\end{array}$ & 6 & 1.0000 & 8.3069 & 3.1151 & 3.1151 & 8.3069 & 0.6640 & 0.7300 & Gamma \\
\hline & tefi & $\operatorname{TrN}+\mathrm{G}$ & 6 & 1.0000 & 3.1913 & 1.0000 & 1.0000 & 5.0207 & - & 0.4440 & Gamma \\
\hline & tub2 & $\mathrm{TIM} 3+\mathrm{G}$ & 6 & 2.6726 & 3.8861 & 1.0000 & 2.6726 & 10.7258 & - & 0.4200 & Gamma \\
\hline & rpb2 & $\operatorname{TrN}+\mathrm{I}+\mathrm{G}$ & 6 & 1.0000 & 4.7971 & 1.0000 & 1.0000 & 13.7321 & 0.4690 & 1.8510 & Gamma \\
\hline & ITS/tef1/tub2/rpb2 & $\mathrm{TIM} 2+\mathrm{I}+\mathrm{G}$ & 6 & 1.2861 & 4.0643 & 1.2861 & 1.0000 & 8.3643 & 0.5010 & 0.6480 & Gamma \\
\hline \multirow[t]{5}{*}{ Neofusicoccum } & ITS & $\mathrm{TIM} 1+\mathrm{I}+\mathrm{G}$ & 6 & 1.0000 & 10.7228 & 2.7330 & 2.7330 & 23.3748 & 0.5420 & 0.5670 & Gamma \\
\hline & tef1 & TPM2uf + G & 6 & 1.6352 & 7.1729 & 1.6352 & 1.0000 & 7.1729 & - & 0.6840 & Gamma \\
\hline & tub2 & $\mathrm{TIM} 3+\mathrm{G}$ & 6 & 1.9226 & 7.3114 & 1.0000 & 1.9226 & 12.7028 & - & 0.2070 & Gamma \\
\hline & $r p b 2$ & $\mathrm{TIM} 3+\mathrm{G}$ & 6 & 2.4608 & 9.3031 & 1.0000 & 2.4608 & 24.9646 & - & 0.2660 & Gamma \\
\hline & ITS/tef1/tub2/rpb2 & $\operatorname{TrN}+\mathrm{I}+\mathrm{G}$ & 6 & 1.0000 & 5.0967 & 1.0000 & 1.0000 & 9.7420 & 0.4430 & 0.7340 & Gamma \\
\hline
\end{tabular}

\begin{tabular}{|c|c|c|c|c|c|c|c|c|c|c|}
\hline \multirow[t]{2}{*}{ Genus } & \multirow[t]{2}{*}{ Dataset } & \multirow[t]{2}{*}{ No. of taxa } & \multirow{2}{*}{$\begin{array}{l}\text { No. of } \\
\text { bp }\end{array}$} & \multicolumn{7}{|c|}{ Maximum parsimony } \\
\hline & & & & PIC $^{d}$ & $\begin{array}{l}\text { No. of } \\
\text { trees }\end{array}$ & $\begin{array}{l}\text { Tree } \\
\text { length }\end{array}$ & $\mathrm{Cl}^{\mathrm{e}}$ & $\mathbf{R I}^{\mathrm{f}}$ & $\mathbf{R C}^{9}$ & $\mathrm{HI}^{\mathrm{h}}$ \\
\hline \multirow[t]{5}{*}{ Botryosphaeria } & ITS & 49 & 530 & 30 & 86 & 51 & 0.8039 & 0.8913 & 0.7165 & 0.1961 \\
\hline & tef1 & 49 & 353 & 115 & 120 & 152 & 0.8684 & 0.9385 & 0.8150 & 0.1316 \\
\hline & tub2 & 42 & 414 & 22 & 35 & 30 & 0.8000 & 0.9063 & 0.7250 & 0.2000 \\
\hline & rpb2 & 30 & 718 & 23 & 4 & 37 & 0.8378 & 0.9483 & 0.7945 & 0.1622 \\
\hline & ITS/tef1/tub2 & 49 & 1297 & 167 & 234 & 241 & 0.8174 & 0.9085 & 0.7427 & 0.1826 \\
\hline \multirow[t]{5}{*}{ Lasiodiplodia } & ITS & 74 & 511 & 50 & 5000 & 91 & 0.6813 & 0.8858 & 0.6035 & 0.3187 \\
\hline & tef1 & 73 & 323 & 135 & 1233 & 415 & 0.6024 & 0.8922 & 0.5375 & 0.3976 \\
\hline & tub2 & 64 & 409 & 41 & 5000 & 60 & 0.7667 & 0.9310 & 0.7138 & 0.2333 \\
\hline & rpb2 & 53 & 532 & 104 & 3297 & 192 & 0.6354 & 0.8649 & 0.5496 & 0.3646 \\
\hline & ITS/tef1/tub2/rpb2 & 74 & 1775 & 330 & 3989 & 854 & 0.5621 & 0.8508 & 0.4782 & 0.4379 \\
\hline \multirow[t]{5}{*}{ Neofusicoccum } & ITS & 99 & 535 & 86 & 1790 & 205 & 0.5512 & 0.8844 & 0.4875 & 0.4488 \\
\hline & tef1 & 98 & 307 & 150 & 5000 & 312 & 0.7308 & 0.9413 & 0.6879 & 0.2692 \\
\hline & tub2 & 98 & 424 & 72 & 1380 & 149 & 0.6040 & 0.8952 & 0.5407 & 0.3960 \\
\hline & rpb2 & 76 & 605 & 116 & 2619 & 201 & 0.6915 & 0.9180 & 0.6348 & 0.3085 \\
\hline & ITS/tef1/tub2/rpb2 & 101 & 1871 & 424 & 3584 & 936 & 0.6090 & 0.8968 & 0.5461 & 0.3910 \\
\hline
\end{tabular}


Table 4 Number of fixed SNPs between newly described species and their phylogenetically close taxa

\begin{tabular}{|c|c|c|c|c|c|c|}
\hline \multirow[t]{2}{*}{ Species } & \multicolumn{6}{|c|}{ Single nucleotide polymorphism comparisons of four loci } \\
\hline & B. puerensis & N. dianense & N. magniconidium & N. ningerense & N. parviconidium & N. yunnanense \\
\hline Botryosphaeria corticis & $13 / 16 / 14 / *^{* a}$ & - & - & - & - & - \\
\hline B. fabicerciana & $1 / 14 / 9 / 12$ & - & - & - & - & - \\
\hline B. fusispora & $1 / 16 / 11 /^{*}$ & - & - & - & - & - \\
\hline B. kuwatsukai & $1 / 10 / * * *$ & - & - & - & - & - \\
\hline B. qingyuanensis & 2/9/9/3 & - & - & - & - & - \\
\hline B. rosaceae & $1 / 13 / 9 /^{*}$ & - & - & - & - & - \\
\hline Neofusicoccum algeriense & $-^{\mathrm{b}}$ & $3 / 1 / 7 / *$ & - & - & - & $3 / 1 / 4 /^{*}$ \\
\hline N. dianense & - & - & - & - & - & $2 / 2 / 3 / 6$ \\
\hline N. hongkongense & - & $4 / 0 / 2 / 4$ & - & - & - & $4 / 2 / 1 / 2$ \\
\hline N. italicum & - & $4 / 0 / 5 / 5$ & - & - & - & $4 / 1 /^{*} / *$ \\
\hline N. macroclavatum & - & - & $9 / 1 / 6 / 2$ & $7 / 1 / 6 / 2$ & - & - \\
\hline N. mangiferae & - & - & - & - & $2 / 5 / 2 / 27$ & - \\
\hline N. microconidium & - & - & - & - & $1 / 3 / 1 / 1$ & - \\
\hline N. ningerense & - & - & $2 / 0 / 2 / 2$ & - & - & - \\
\hline N. parvum & - & $3 / 2 / 5 / 5$ & - & - & - & $1 / 4 / 2 / 0$ \\
\hline
\end{tabular}

a The number means the difference of two species in four loci, ITS/tef1/tub2/rpb2; "*" represents the sequence is unavailable

b "- " represent the sequences between two species were not compared

Isolates in Group C clustered with B. fusispora, B. fabicerciana, B. kuwatsukai, B. puerensis and B. rosaceae in the ITS tree (Fig. 2a). They were closely related to $B$. fusispora and B. fabicerciana in the tef1 tree (Fig. 2b) and clustered with B. fusispora in the tub2 tree (Fig. 2c). They clustered with or were close to B. fabicerciana in the $r p b 2$ tree, but could not be compared with B. fusispora because sequence data for this region are not available for that species (Fig. 2d). Based on tef1 data (Fig. $2 \mathrm{~b})$, three independent clades emerged accommodating isolates CSF5683, CSF6021 and CSF6056; CSF5871 and CSF5872; and CSF6063 and CSF6178, but they had only three or four fixed SNPs different to their phylogenetically closest species B. fusispora. These isolates in Group $C$ were phylogenetically close to $B$. fusispora based on ITS, tef1, tub2 and the combined ITS/tefl/tub2 trees (Fig. 2) and they were identified as that species.

\section{Species in Lasiodiplodia}

Analyses were conducted for Lasiodiplodia based on sequences for the ITS, tef1, tub2 and rpb2 loci. Based on phylogenetic analyses for these loci and the combined ITS/tef1/tub2/rpb2 datasets, two Lasiodiplodia isolates clustered in one group (Group D) (Fig. 3). These isolates were phylogenetically related to $L$. pseudotheobromae and various other species based on ITS and tub2 trees (Fig. 3a, c). They were closest L. pseudotheobromae based on tef1 tree (Fig. 3b), and clustered with L. pseudotheobromae based on $r p b 2$ tree (Fig. 3d). The tree based on the combined ITS/tef1/tub2/rpb2 dataset also showed that the two isolates making up Group D were phylogenetically closely related to $L$. pseudotheobromae and they were treated as that species (Fig. 3e).

\section{Species in Neofusicoccum}

The Neofusicoccum isolates resided in seven groups based on ITS, tub2 and the combined ITS/tef1/tub2/ $r p b 2$ datasets (Groups E-K). For the tef1 dataset, there were six groups including Groups E-H, Group I that clustered with Group J and Group K. For the rpb2 dataset, there were six groups including Group E that clustered with Group F and Groups G-K (Fig. 4).

Isolates in Group E were closely related to N. parvum and various other species based on the ITS, tef1 and $r p b 2$ trees (Fig. 4a, b, d) and they also clustered with $N$. parvum based on the tub2 tree (Fig. 4c). They formed multiple independent clades based on the ITS, tef1, rpb2 and the combined ITS/tef1/tub2/rpb2 trees (Fig. 4a, b, d, e). Based on these analyses of five datasets, isolates in Group E were treated as N. parvum (Fig. 4).

Isolates in Group F were closely related to $N$. algeriense based on phylogenetic analyses of tef1 dataset (Fig. $4 \mathrm{~b})$. They clustered with $N$. mangiferae and $N$. parvum in the rpb2 tree (Fig. 4d). Isolates in Group F formed one independent clade that was distinct from all known species based on ITS and tub2 trees, and isolates CSF6034 and CSF6142 (ex-type) formed a distinct lineage in tef1 tree (Fig. $4 \mathrm{a}-\mathrm{c}$ ). In the combined tree, isolates CSF6034 and CSF6142 (ex-type), and other isolates in Group $\mathrm{F}$ formed an independent sub-clade (Fig. 4e). 

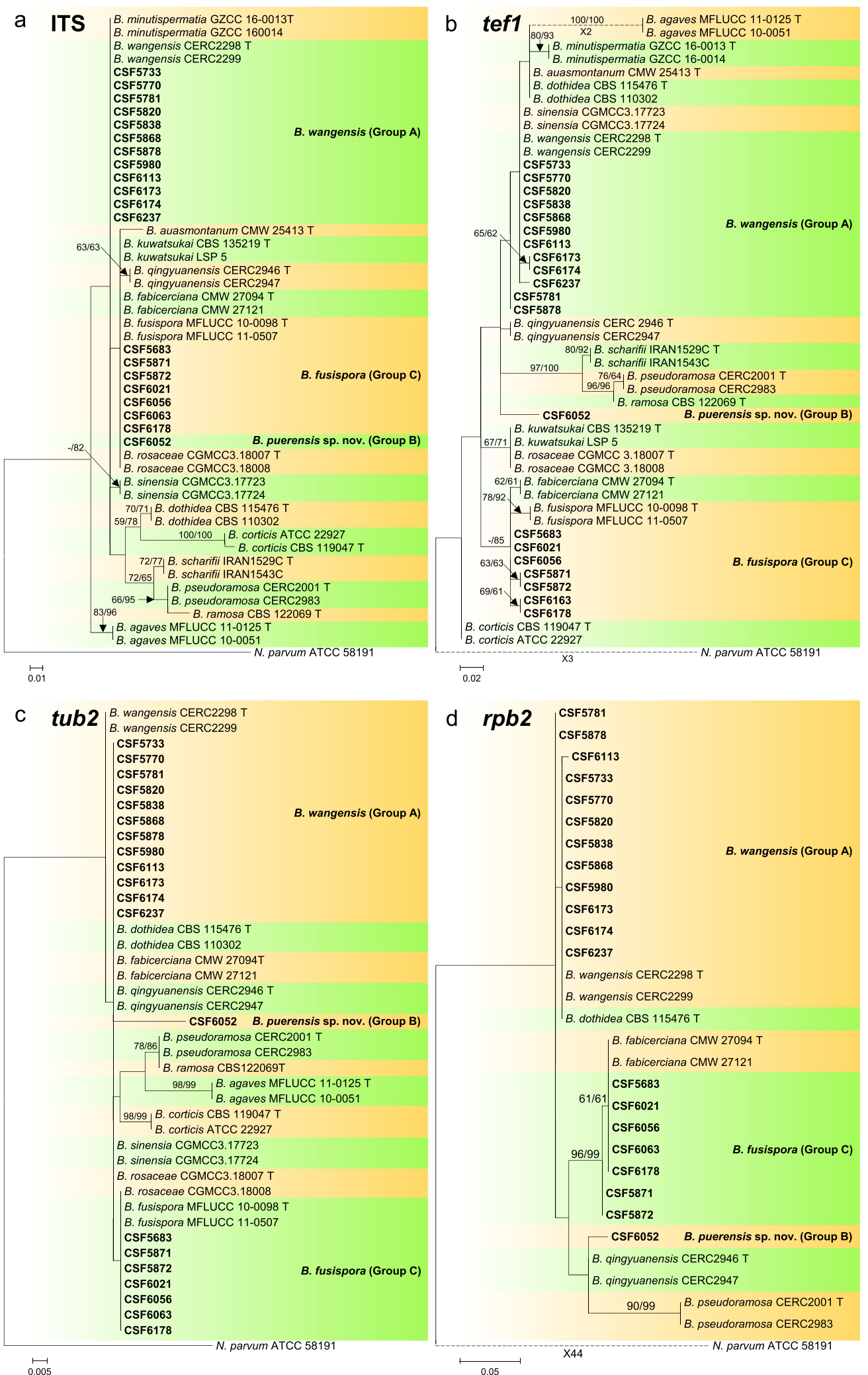

Fig. 2 Phylogenetic trees based on maximum likelihood (ML) analyses for species in Botryosphaeria. a. ITS; b. tef1; c. tub2; d. rpb2; e. combination of ITS, tef1 and tub2. Isolates sequenced in this study are in bold. Bootstrap support values $\geq 60 \%$ for ML and MP are presented above branches as follows: ML/MP, bootstrap support values $<60 \%$ are marked with ' - ,' and absent are marked with '*'. Ex-type isolates are marked with T'. The trees were rooted to N. parvum (ATCC 58191) 


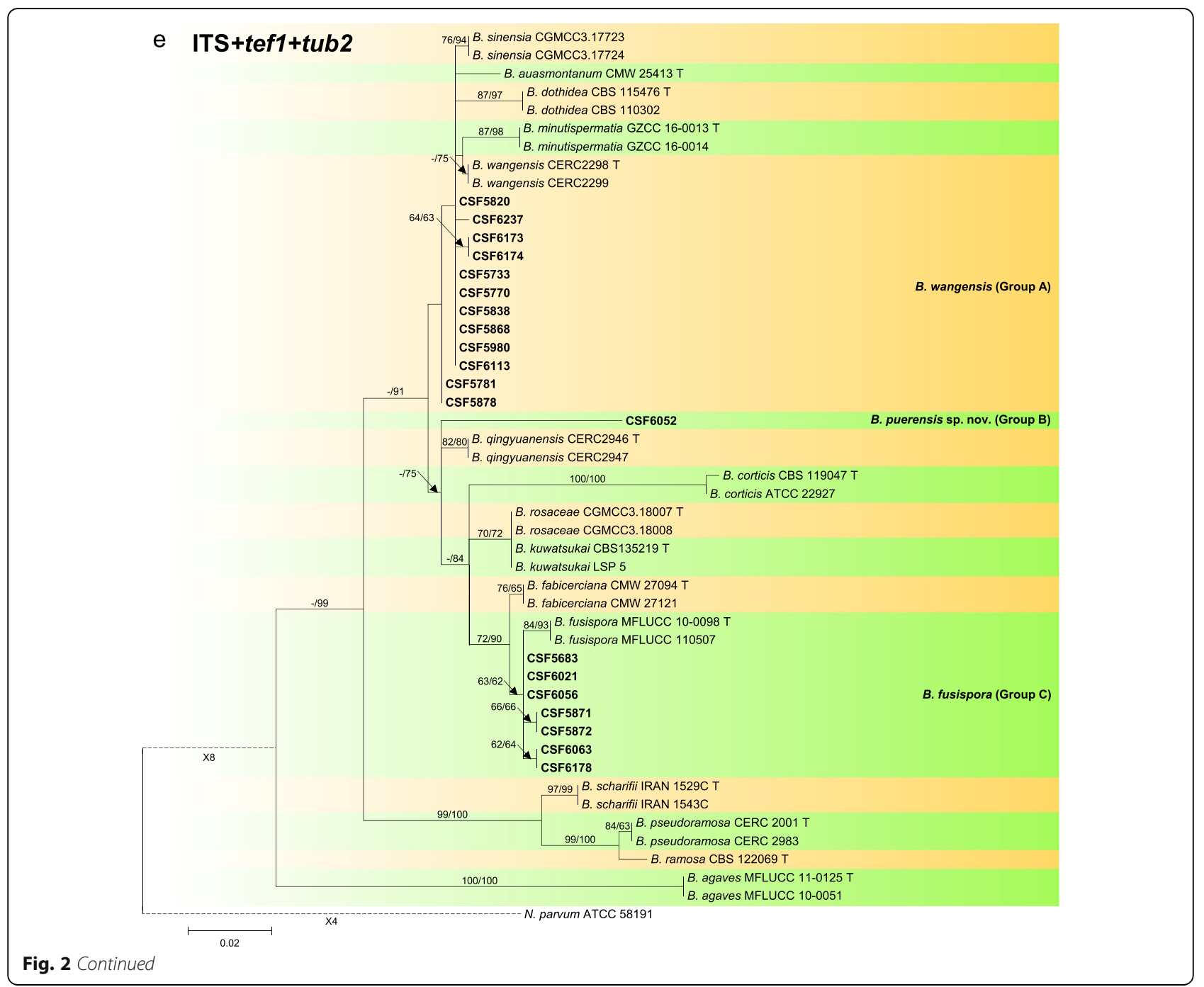

Seven fixed SNPs also differentiated isolates in Group F from their phylogenetically closest relatives $N$. algeriense and $N$. parvum in the ITS, tef 1 and tub2 regions, and five fixed SNPs differentiated them from $N$. italicum in the ITS and tef1 regions (tub2 not available for N. italicum) (Table 4). These isolates were consequently treated as representing a novel species.

Isolate CSF6037 in Group G clustered with N. kwambonambiense in the tub2 tree (Fig. 4c). It also clustered with $N$. kwambonambiense and various other species in the tef1 tree (Fig. 4b), and was most closely related to that species in the ITS, $r p b 2$ and the combined ITS/tef1/ tub2/rpb2 trees (Fig. 4a, d, e). Isolate CSF6037 was consequently identified as N. kwambonambiense.

Isolates in Group $\mathrm{H}$ clustered with $N$. illicii in the ITS tree (Fig. 4a) and with $N$. hongkongense in the tef1 tree (Fig. 4b). Based on the tub2 and rpb2 trees, these isolates formed an independent clade that was distinct from all known species of Neofusicoccum (Fig. 4c, d). This clade was well supported by high bootstrap values in the tub2 and combined ITS/tef1/tub2/ rpb2 trees (tub2, ML/MP $=87 \% / 87 \%$; ITS/tef1/tub2/ $r p b 2, \mathrm{ML} / \mathrm{MP}=95 \% / 98 \%$ ) (Fig. 4c, e). There were also ten fixed SNPs differentiating isolates in Group $\mathrm{H}$ from their phylogenetically closest species, $N$. hongkongense (Table 4). Consequently, isolates in Group $\mathrm{H}$ were considered to represent a novel species of Neofusicoccum.

Isolates in both Group I and Group J formed a single clade that clustered with $N$. illicii in the tef1 tree, and isolates in Group I clustered with N. illicii in the tub2 tree (Fig. 4c). But isolates in these two groups formed two independent clades in the ITS and rpb2 trees (Fig. 4a, d), and those in Group J also formed an independent clade in the $t u b 2$ tree (Fig. 4c). The two independent clades were supported by high 

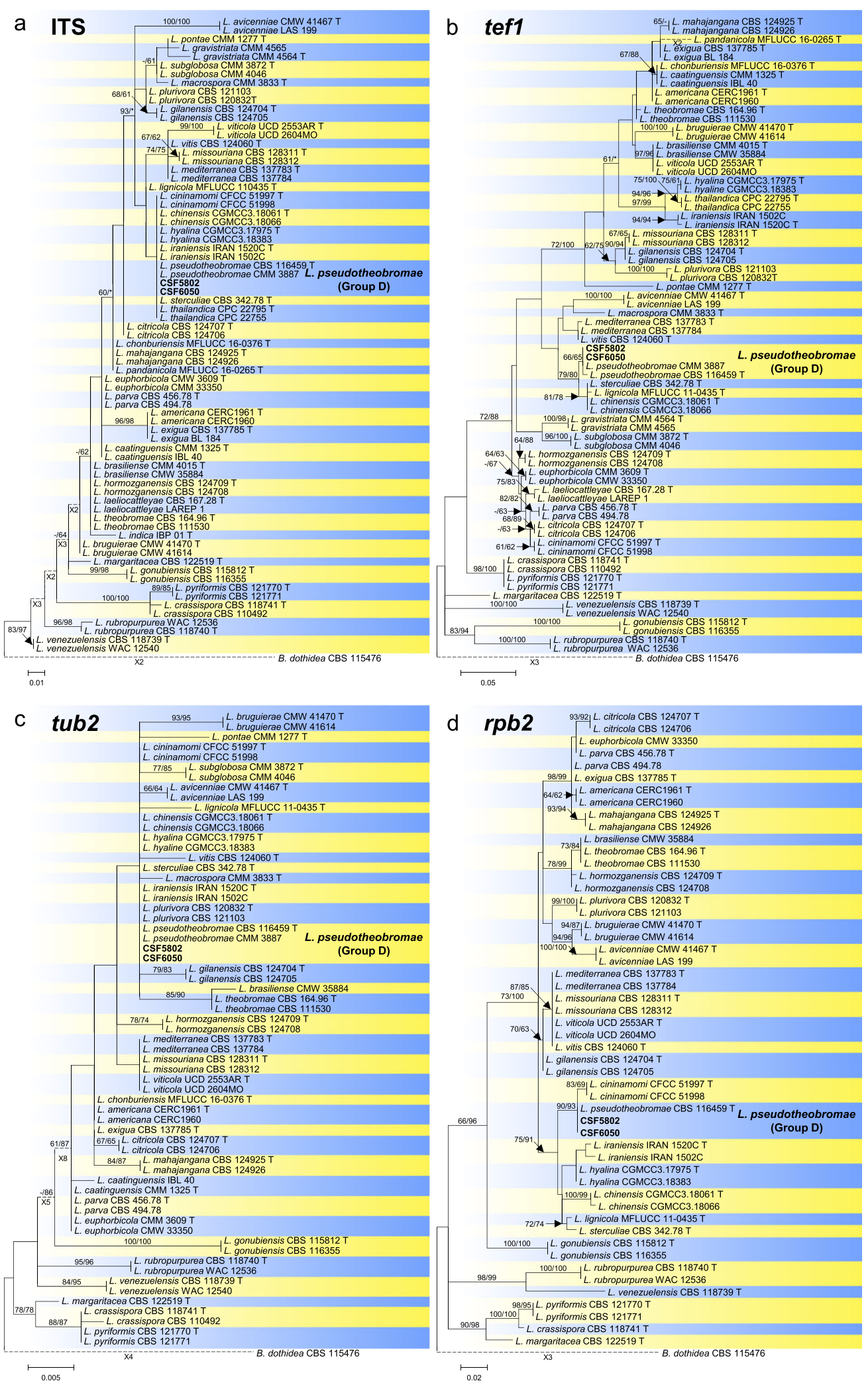

Fig. 3 Phylogenetic trees based on maximum likelihood (ML) analyses for species in Lasiodiplodia. a. ITS; b. tefl; c. tub2; d. rpb2; e. combination of ITS, tef1, tub2 and $r p b 2$. Isolates sequenced in this study are in bold. Bootstrap support values $\geq 60 \%$ for ML and MP are presented above branches as follows: ML/MP, bootstrap values $<60 \%$ are marked with '"', and absent are marked with '*' Ex-type isolates are marked with T'. The trees were rooted to B. dothidea (CBS 115476) 


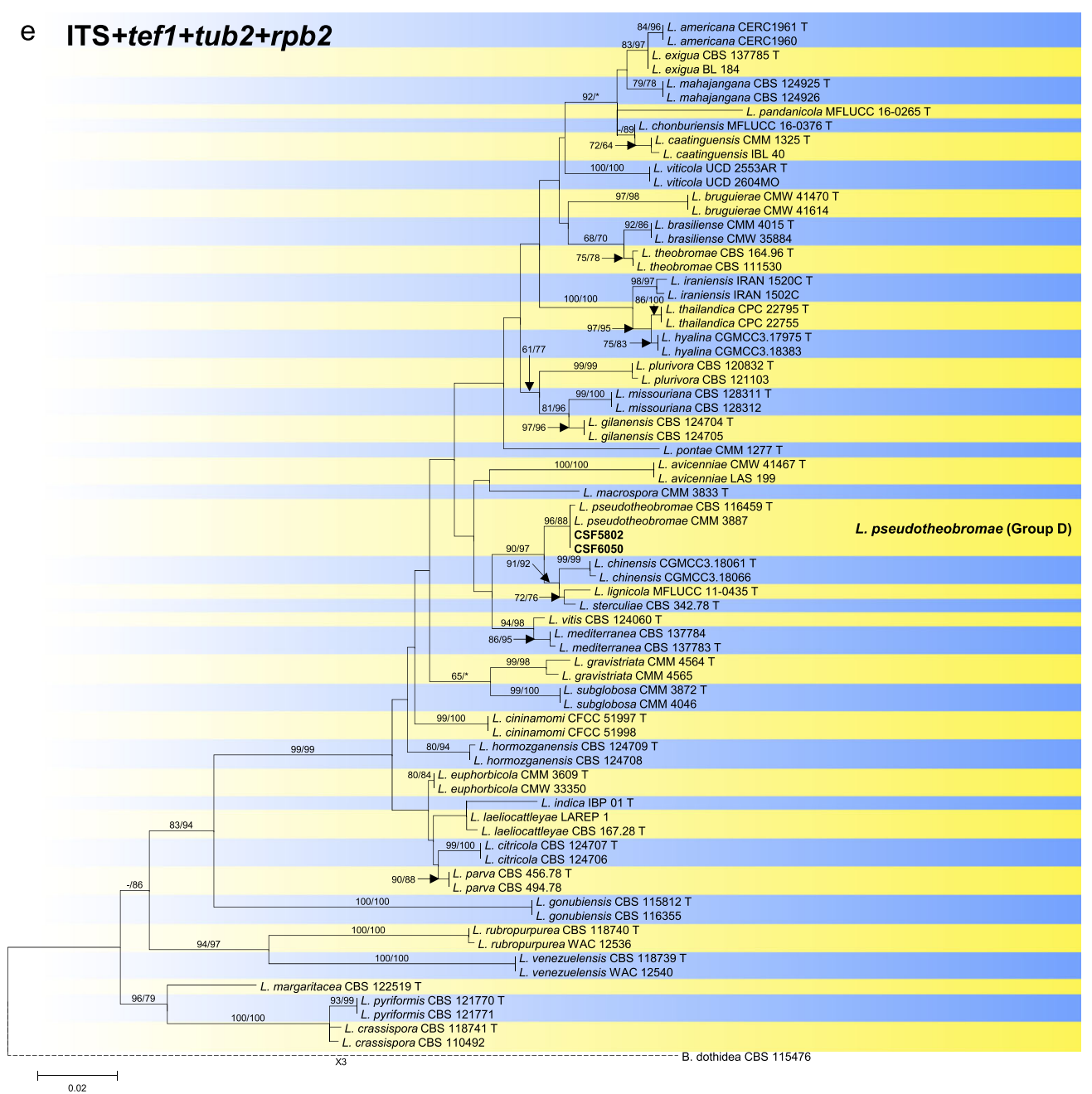

Fig. 3 Continued

bootstrap values in the combined ITS/tef1/tub2/rpb2 tree (Group I, ML/MP = 99\%/98\%; Group J, ML/MP = 94\%/85\%) (Fig. 4e). In addition, there were six fixed SNPs observed between isolates in Group I and Group J (Table 4). Thus, isolates in Group I and Group J were considered to represent two undescribed species of Neofusicoccum.

Isolates in Group $\mathrm{K}$ clustered with $N$. microconidium in the ITS tree (Fig. 4a). However, they formed a distinct clade that was separated from all known species in the tef1, tub2, and rpb2 trees (Fig. $4 \mathrm{~b}-\mathrm{d}$ ). These isolates resided in a single clade, which was supported by high bootstrap values in the combined ITS/tef $1 /$ tub2/rpb2 tree $(\mathrm{ML} / \mathrm{MP}=99 \% / 98 \%)$ (Fig. 4e). There were also six fixed SNPs observed between isolates in Group $\mathrm{K}$ and their phylogenetically closest relative, N. microconidium (Table 4). Consequently, isolates in Group $\mathrm{K}$ were considered to represent a novel species.

\section{Morphology and taxonomy}

Based on analyses of DNA sequence data, the isolates obtained in the present study clustered in 11 phylogenetic groups of the Botryosphaeriaceae. The culture morphology of all isolates in these groups was morphologically similar to other species of Botryosphaeriaceae, consistent with the fact that this characteristic has little taxonomic significance.

Isolates representing Groups B, F and $\mathrm{H}-\mathrm{K}$ were identified as novel species based on the phylogenetic analyses. Representative isolates for these groups were selected to induce fruiting structures (Table 1). With the exception of those in Group J (isolates CSF6028 and CSF6030), that did not sporulate, these putatively novel 

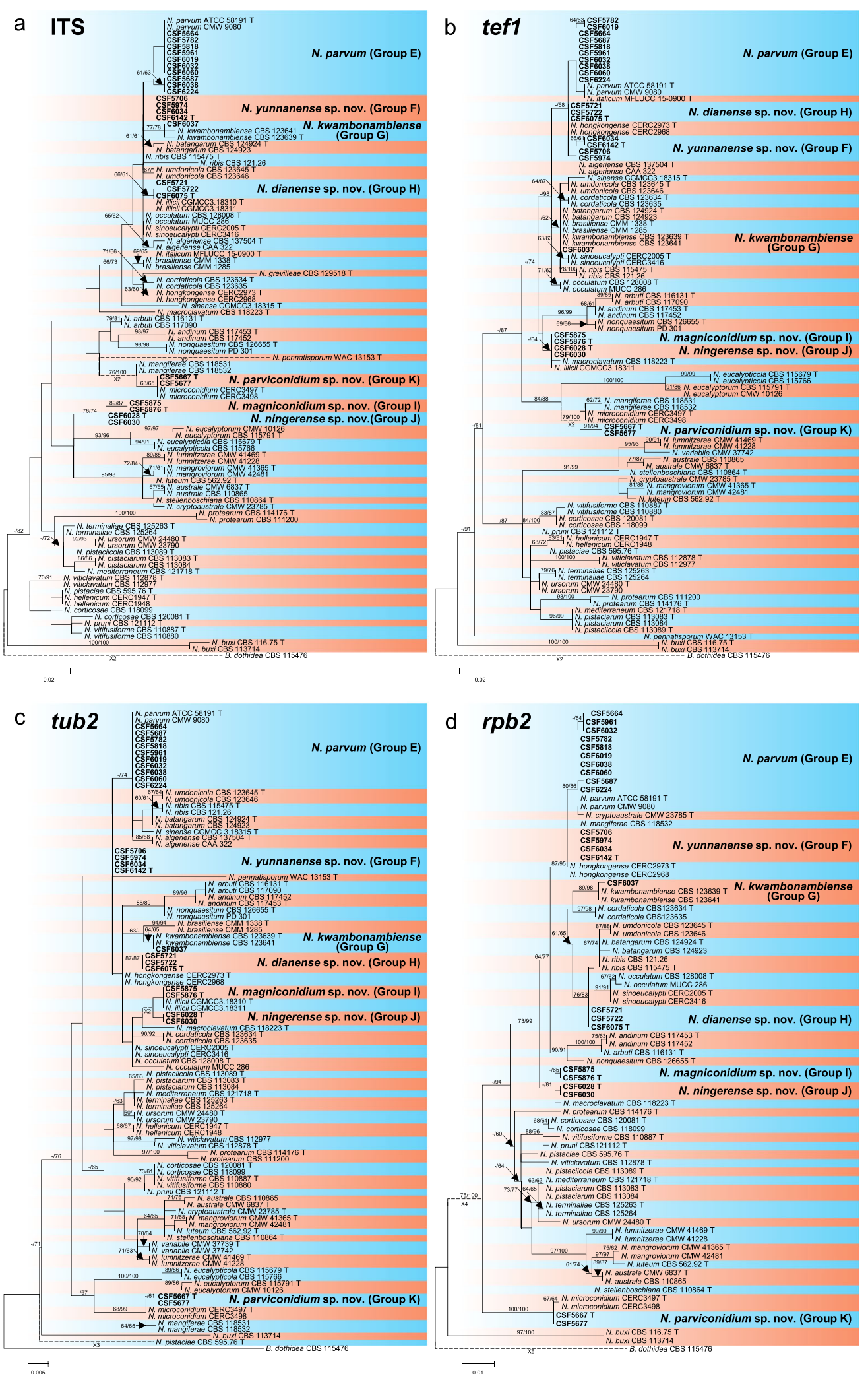

Fig. 4 Phylogenetic trees based on maximum likelihood (ML) analyses for species in Neofusicoccum. a. ITS; b. tef1; c. tub2; d. rpb2; e. combination of ITS, tef1, tub2 and $r p b 2$. Isolates sequenced in this study are in bold. Bootstrap support values $\geq 60 \%$ for ML and MP are presented above branches as follows: ML/MP, bootstrap support values $<60 \%$ are marked with ' - , and absent are marked with '*'. Ex-type isolates are marked with T'. The trees were rooted to B. dothidea (CBS 115476 ) 


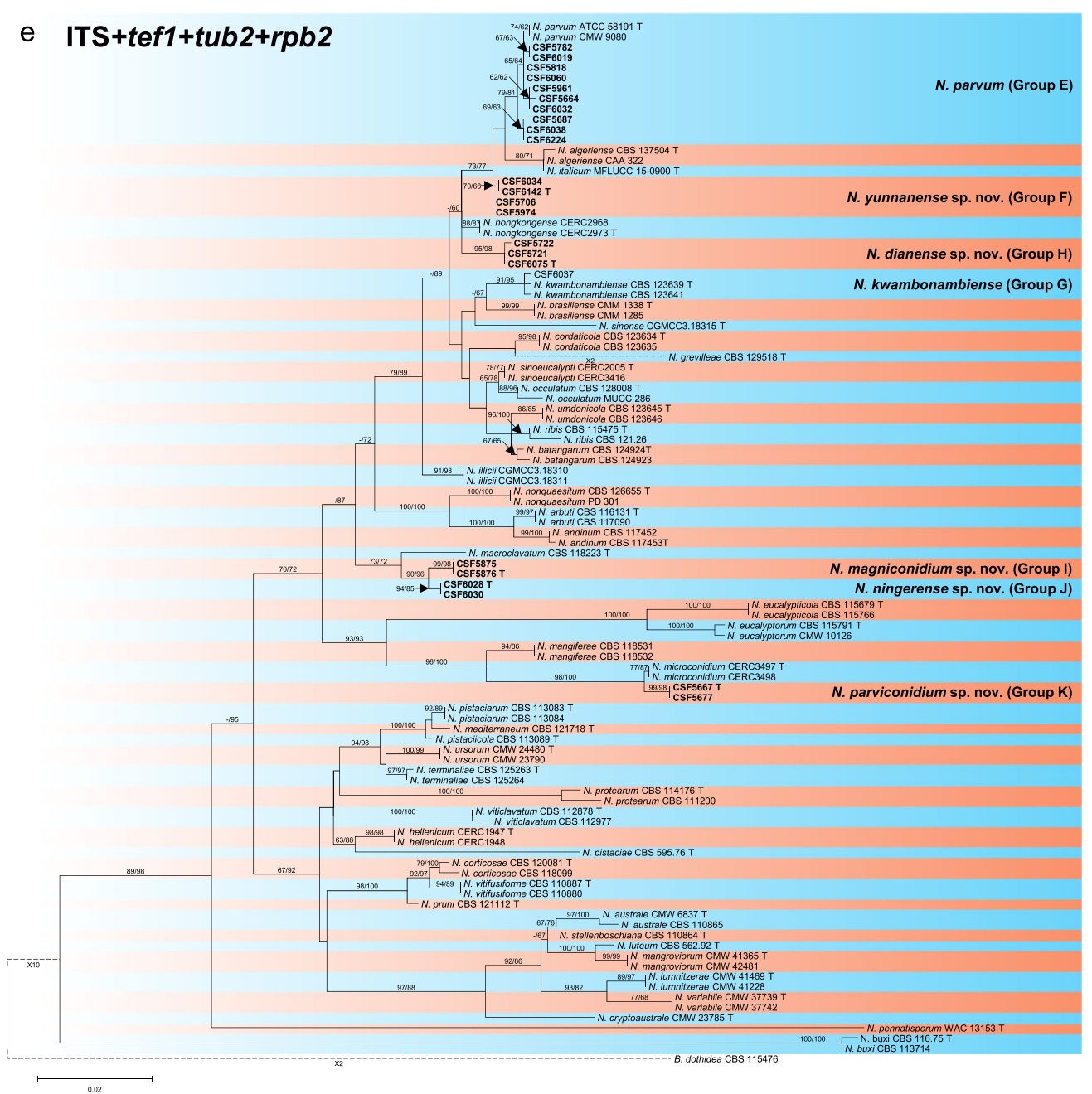

Fig. 4 Continued

taxa produced only asexual structures. Morphological differences were observed for the phylogenetically distinct species (Table 5) and these have been included in their descriptions. Based primarily on phylogenetic inference but including available morphological characteristics, isolates in Groups B, F, H-K were recognised as representing six previously undescribed species for which names are proposed as follows:

Botryosphaeria puerensis G.Q. Li \& S.F. Chen, sp. nov.

MycoBank MB834102. (Fig. 5).

Etymology: Name reflects the PuEr Region where the fungus was isolated for the first time.

Diagnosis: Botryosphaeria puerensis produces shorter conidia than $B$. corticis, but longer conidia than other species of Botryosphaeria.

Type: China: YunNan Province, PuEr Region, JingGu County (GPS $23^{\circ} 20^{\prime} 21^{\prime \prime} \mathrm{N}, 100^{\circ} 54^{\prime} 38^{\prime \prime} \mathrm{E}$ ), from twigs of one E. urophylla $\times$ E. grandis tree, 16 November 2014, S.F. Chen \& G.Q. Li, fruiting structures induced on needles of Pinus sp. on water agar (HMAS255719 - holotype, CSF6052 = CGMCC3.20081 - ex-type culture).

Description: Sexual state unknown. Conidiomata pycnidial, produced on pine needles on WA medium within 4-6 wk., globose to ovoid, dark brown to black, up to $662 \mu \mathrm{m}$ wide, $1041 \mu \mathrm{m}$ high, embedded in needle tissue, semi-immersed to superficial, unilocular, with a central ostiole. Conidiophores reduced to conidiogenous cells. Conidiogenous cells holoblastic, discrete, hyaline, cylindrical to lageniform, phialidic with periclinal thickening, $(6-) 7-14(-20) \times(1.5-) 2-3.5(-4) \quad \mu \mathrm{m}$. Paraphyses not seen. Conidia hyaline, thin-walled, smooth with granular 
Table 5 Conidial measurements of Botryosphaeriaceae species described in this study and comparison with phylogenetically close species in previous studies

\begin{tabular}{|c|c|c|c|c|}
\hline Species $^{a}$ & Conidial size $(\mu \mathrm{m})(\mathrm{L} \times \mathrm{W})^{\mathrm{b}}$ & Mean $(\mu \mathrm{m})(L \times W)^{c}$ & $L / W^{d}$ & Reference \\
\hline Botryosphaeria corticis & $(20.5-) 23.5-32.5(-34.5) \times(5.0-) 5.5-7(-7.5)$ & $28.9 \times 6.4$ & 4.5 & Phillips et al. 2006 \\
\hline B. fabicerciana & $(16.5-) 19.5-24.5(-26) \times(4.5-) 5-6.5(-7.5)$ & $22.0 \times 5.8$ & 3.8 & Chen et al. 2011 \\
\hline B. fusispora & $16-22 \times 4-5.5$ & $20.0 \times 5.0$ & 4.0 & Liu et al. 2012 \\
\hline B. kuwatsukai & $(18.5-) 20-24.5(-26) \times 5-7(-8)$ & $22.3 \times 6.2$ & 3.6 & Xu et al. 2015 \\
\hline B. puerensis ${ }^{a}$ & $(22.5-) 24-29.5(-32) \times(4.5-) 5.5-7.5(-8)$ & $26.8 \times 6.4$ & 4.2 & This study \\
\hline B. qingyuanensis & $(15-) 19.5-24.5(-28.5) \times(5-) 6-6.5(-7.5)$ & $22.0 \times 6.2$ & 3.5 & Li et al. 2018 \\
\hline B. rosaceae & $20-31 \times 6-8$ & $26.2 \times 6.7$ & 3.9 & Zhou et al. 2017 \\
\hline Neofusicoccum algeriense & $(14.5-) 17-18(-21) \times(4.5-) 5.5-5.7(-6.5)$ & $17.6 \times 5.6$ & 3.1 & Berraf-Tebbal et al. 2014 \\
\hline N. dianense $e^{a}$ & $(16-) 16.5-21(-24) \times(4.5-) 5-5.5(-6)$ & $18.9 \times 5.2$ & 3.6 & This study \\
\hline N. hongkongense & $(11.5-) 13-15.5(-17.5) \times(4-) 4.5-5(-5.5)$ & $14.1 \times 4.7$ & 3.0 & Li et al. 2018 \\
\hline N. italicum & $13-18.5 \times 3.5-6$ & $15.8 \times 5.2$ & - $^{\mathrm{e}}$ & Marin-Felix et al. 2017 \\
\hline N. macroclavatum & $(19-) 25-35(-41) \times(5-) 6-8(-10)$ & $30.3 \times 7.1$ & 4.2 & Burgess et al. 2005 \\
\hline N. magniconidium ${ }^{a}$ & $(27-) 27.5-30(-34) \times(5.5-) 6-7.5(-8)$ & $29.1 \times 6.7$ & 4.3 & This study \\
\hline N. mangiferae & $(11-) 12-15(-17.5) \times 5-6.6$ & $13.6 \times 5.4$ & $2.0-2.5$ & Slippers et al. 2005 \\
\hline N. microconidium & $(10-) 11.5-13(-14.5) \times(4-) 4.5-5.5(-6)$ & $12.3 \times 5.0$ & 2.5 & Li et al. 2018 \\
\hline N. parviconidium ${ }^{a}$ & $(9.5-) 10.5-11.5(-12.5) \times(4.4-) 5-5.5(-6)$ & $10.9 \times 5.2$ & 2.1 & This study \\
\hline N. parvum & $(12-) 13.5-21(-24) \times 4-6(-10)$ & $17.1 \times 5.5$ & 3.2 & Phillips et al. 2013 \\
\hline N. yunnanense $e^{a}$ & $(13-) 13.5-17.5(-20) \times(3.5-) 4-4.5(-5)$ & $15.6 \times 4.4$ & 3.5 & This study \\
\hline
\end{tabular}

a Species in bold are novel species described in this study

${ }^{\mathrm{b}}$ Minimum-(average - standard deviation)-(average + standard deviation)-maximum or minimum-maximum, $\mathrm{L} \times \mathrm{W}=$ length $\times$ width

${ }^{c} L \times W=$ average length $\times$ average width

${ }^{d} \mathrm{~L} / \mathrm{W}=$ average length/average width

e "-" indicates no data was available

contents, unicellular, aseptate narrowly fusiform, base subtruncate to bluntly rounded, (22.5-)24-29.5($32) \times(4.5-) 5.5-7.5(-8) \mu \mathrm{m}$ (av. of 100 conidia $26.8 \times$ $6.4 \mu \mathrm{m} ; \mathrm{L} / \mathrm{W}=4.2$ ) (Table 5).

Culture characteristics: Colonies on MEA medium having fluffy mycelia with uneven margins and a few cottony aerial mycelia reaching to the lids of Petri plates, mycelial mat appressed, sparse to moderately dense. Colony mycelia initially white, becoming smoke gray (19"' $f$ ) to olivaceous (21"k) at the surface and olivaceous gray $\left(23^{\prime \prime \prime \prime} \mathrm{b}\right)$ to iron gray $\left(23^{\prime \prime \prime \prime} \mathrm{k}\right)$ at the reverse after $10 \mathrm{~d}$. Optimal growth temperature $25^{\circ} \mathrm{C}$. No growth at $5{ }^{\circ} \mathrm{C}$ and $40^{\circ} \mathrm{C}$. After $4 \mathrm{~d}$, colonies at $10^{\circ} \mathrm{C}, 15^{\circ} \mathrm{C}, 20^{\circ} \mathrm{C}$, $25^{\circ} \mathrm{C}, 30^{\circ} \mathrm{C}$ and $35^{\circ} \mathrm{C}$ reaching $14 \mathrm{~mm}, 31 \mathrm{~mm}, 43 \mathrm{~mm}$, $64 \mathrm{~mm}, 62 \mathrm{~mm}$ and $10 \mathrm{~mm}$, respectively.

Host: E. urophylla $\times$ E. grandis.

Distribution: Currently only known from PuEr Region in YunNan Province, China.

Notes: Botryosphaeria puerensis is phylogenetically closely related to B. corticis, B. fabicerciana, B. fusispora, B. kuwatsukai, B. rosaceae and B. qingyuanensis (Fig. 2). Conidia (Table 5) of B. puerensis (av. $26.8 \times 6.4$; L/W = 4.2) are larger than in those species with the exception of $B$. corticis (av. $28.9 \times 6.4 ; \mathrm{L} / \mathrm{W}=4.5$ ) (Phillips et al.
2006; Chen et al. 2011; Liu et al. 2012; Xu et al. 2015; Zhou et al. 2017; Li et al. 2018).

Neofusicoccum dianense G.Q. Li \& S.F. Chen, sp. nov.

MycoBank MB834103. (Fig. 6).

Etymology: Name refers to "Dian", an ancient kingdom of YunNan Province, where the type specimen was collected.

Diagnosis: Based on phylogenetic inference, Neofusicoccum dianense resides in 'N. parvum / N. ribis' complex. It produces the longer conidia than its closest phylogenetic relatives including $N$. algeriense, $N$. hongkongense, $N$. italium, N. parvum, N. yunnanense. The optimal growth temperature of $N$. dianense also differs from that of $N$. yunnanense.

Type: China: YunNan Province, PuEr Region, JingGu County (GPS $23^{\circ} 23^{\prime} 58^{\prime \prime} \mathrm{N}, 100^{\circ} 50^{\prime} 37^{\prime \prime} \mathrm{E}$ ), from twigs of one E. urophylla $\times$ E. grandis tree, 16 November 2014, S.F. Chen \& G.Q. Li, fruiting structures induced on 

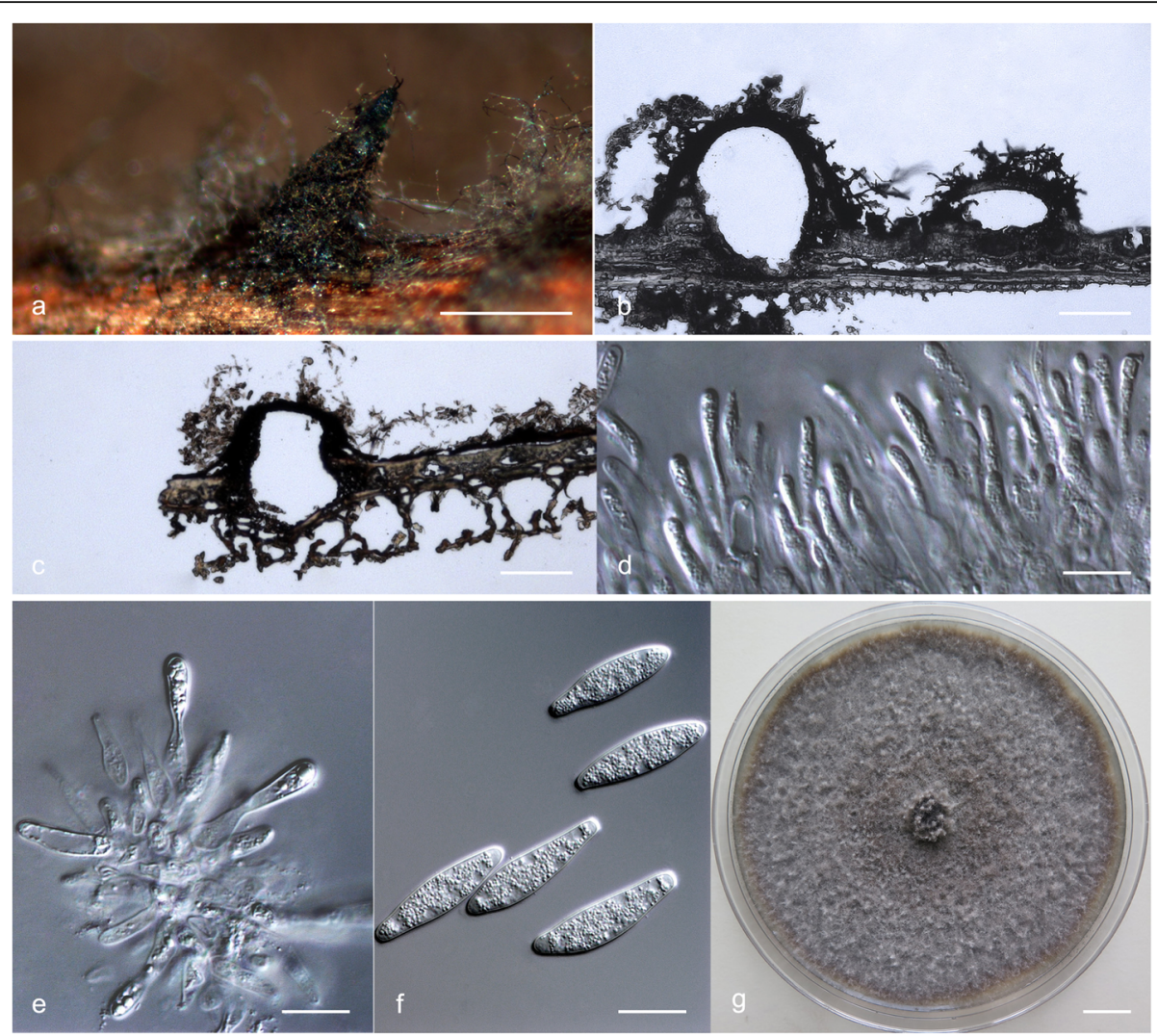

Fig. 5 Botryosphaeria puerensis. a. Conidiomata formed on pine needle culture; b, c. Longitudinal section through conidiomata; $\mathbf{d}$, e. Conidiogenous cells and developing conidia; f. Conidia; $\mathbf{g}$. Living culture after $10 \mathrm{~d}$ on 2\% MEA (front). Scale bars: $a=500 \mu \mathrm{m} ; \mathrm{b}, \mathrm{c}=100 \mu \mathrm{m} ; \mathrm{d}-\mathrm{f}=10 \mu \mathrm{m} ; \mathrm{g}=1 \mathrm{~cm}$
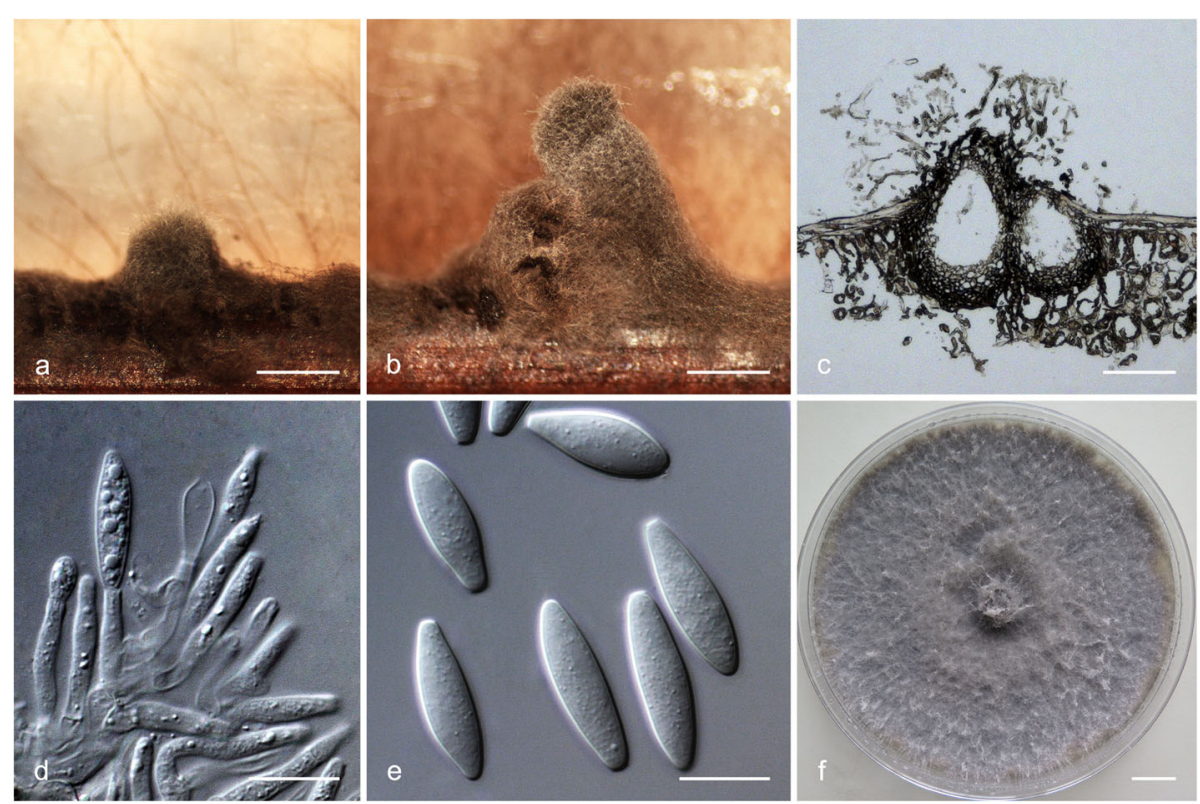

Fig. 6 Neofusicoccum dianense. a, b. Conidiomata formed on pine needle culture; $\mathbf{c}$. Longitudinal section through conidiomata; d. Conidiogenous cells and developing conidia; e. Conidia; f. Living culture after $10 \mathrm{~d}$ on 2\% MEA (front). Scale bars: $a, b=500 \mu m ; c=100 \mu m ; d, e=10 \mu m ; f=1 \mathrm{~cm}$ 
needles of Pinus sp. on water agar (HMAS255720 holotype, CSF6075 = CGMCC3.20082 - ex-type culture).

Description: Sexual state unknown. Conidiomata pycnidial, produced on pine needles on WA medium within 4-6 wk., globose to ovoid, dark brown to black, up to $1363 \mu \mathrm{m}$ wide, $2298 \mu \mathrm{m}$ high, embedded in needle tissue, semi-immersed to superficial, unilocular, with a central ostiole. Conidiophores reduced to conidiogenous cells. Conidiogenous cells holoblastic, discrete, hyaline, cylindrical to lageniform, phialidic with periclinal thickening, $(8.5-) 10.5-15(-16.5) \times(2-) 2.5-3(-3.5) \mu \mathrm{m}$. Paraphyses not seen. Conidia hyaline, thin-walled, smooth with granular contents, unicellular, aseptate narrowly fusiform, base subtruncate to bluntly rounded, (16-)16.5$21(-24) \times(4.5-) 5-5.5(-6) \mu \mathrm{m}$ (av. of 100 conidia $18.9 \times$ $5.2 \mu \mathrm{m} ; \mathrm{L} / \mathrm{W}=3.6$ ) (Table 5).

Culture characteristics: Colonies on MEA medium with fluffy mycelia with uneven margins and a few cottony aerial mycelia reaching to the lids of Petri plates, mycelial mat appressed, sparse to moderately dense. Colony mycelia initially white, becoming pale mouse grey $\left(15^{\prime \prime \prime \prime} \mathrm{d}\right)$ to mouse grey $\left(13^{\prime \prime \prime} \mathrm{i}\right)$ at the surface and olivaceous grey $\left(23^{\prime \prime \prime \prime} \mathrm{b}\right)$ to iron grey $\left(23^{\prime \prime \prime \prime} \mathrm{k}\right)$ at the reverse after $10 \mathrm{~d}$. Optimal growth temperature $25^{\circ} \mathrm{C}$. No growth at $5{ }^{\circ} \mathrm{C}$ and $40^{\circ} \mathrm{C}$. After $4 \mathrm{~d}$, colonies at $10^{\circ} \mathrm{C}$, $15^{\circ} \mathrm{C}, 20^{\circ} \mathrm{C}, 25^{\circ} \mathrm{C}, 30^{\circ} \mathrm{C}$ and $35^{\circ} \mathrm{C}$ reaching $16 \mathrm{~mm}, 47$ $\mathrm{mm}, 71 \mathrm{~mm}, 86 \mathrm{~mm}, 73 \mathrm{~mm}$ and $12 \mathrm{~mm}$, respectively.

Host: E. globulus, E. urophylla $\times$ E. grandis and Eucalyptus sp.
Distribution: Currently known from PuEr and HongHe Regions in YunNan Province, China.

Notes: Neofusicoccum dianense is phylogenetically closely related to $N$. algeriense, $N$. hongkongense, $N$. italium, $N$. parvum and $N$. yunnanense (Fig. 4). The conidia (Table 5) of $N$. dianense (av. $18.9 \times 5.2 ; \mathrm{L} / \mathrm{W}=3.6$ ) are larger than those of $N$. hongkongense (av. $14.1 \times 4.7 ; \mathrm{L} / \mathrm{W}=3.0$; $\mathrm{Li}$ et al. 2018) and $N$. yunnanense (av. $15.6 \times 4.4 ; \mathrm{L} / \mathrm{W}=3.5$ ), and longer than those of $N$. algeriense (av. $17.6 \times 5.6$; $\mathrm{L} / \mathrm{W}=3.1$; Berraf-Tebbal et al. 2014), $N$. italium (av. $15.8 \times 5.2 ; \mathrm{L} / \mathrm{W}=$ 3.0; Marin-Felix et al. 2017) and N. parvum (av. $17.1 \times 5.5$; $\mathrm{L} / \mathrm{W}=3.2$; Phillips et al. 2013).

Additional specimens examined: China: YunNan Province, HongHe Region, PingBian County (GPS $23^{\circ} 05^{\prime} 36^{\prime \prime} \mathrm{N}, 103^{\circ} 31^{\prime} 52^{\prime \prime} \mathrm{E}$ ), from twigs of one E. globulus tree, 13 November 2014, S.F. Chen \& G.Q. Li, fruiting structures induced on needles of Pinus sp. on water agar (HMAS255721, culture CSF5721 = CGMC C3.20075); YunNan Province, HongHe Region, PingBian County (GPS $\left.23^{\circ} 05^{\prime} 36^{\prime \prime} \mathrm{N}, 103^{\circ} 31^{\prime} 52^{\prime \prime} \mathrm{E}\right)$, from twigs of one E. globulus tree, 13 November 2014, S.F. Chen \& G.Q. Li (culture CSF5722); YunNan Province, HongHe Region, MengZi County (GPS 2312'24"N, $\left.103^{\circ} 30^{\prime} 58^{\prime \prime} \mathrm{E}\right)$, from twigs of one Eucalyptus tree, 14 November 2014, S.F. Chen \& G.Q. Li (culture CSF5840).

Neofusicoccum magniconidium G.Q. Li \& S.F. Chen, sp. nov.
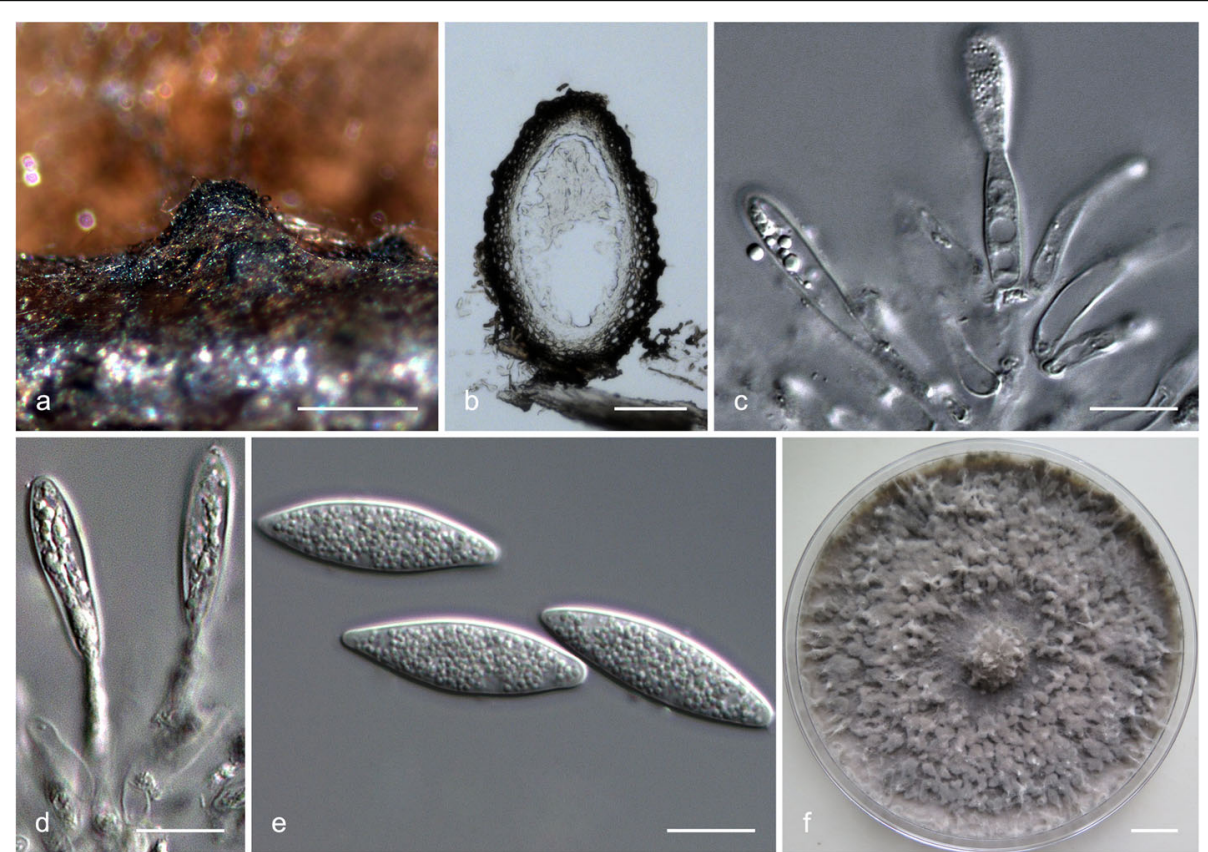

Fig. 7 Neofusicoccum magniconidium. a. Conidiomata formed on pine needle culture; b. Longitudinal section through conidioma; $\mathbf{c}$, d Conidiogenous cells and developing conidia; e. Conidia; f. Living culture after $10 \mathrm{~d}$ on $2 \%$ MEA (front). Scale bars: $a=500 \mu \mathrm{m} ; \mathrm{b}=100 \mu \mathrm{m} ; \mathrm{c}-\mathrm{e}=10 \mu \mathrm{m} ; \mathrm{f}=1 \mathrm{~cm}$ 
MycoBank MB834104. (Fig. 7).

Etymology: Name refers to the exceptionally large conidia in this species.

Diagnosis: Neofusicoccum magniconidium is phylogenetically closely related to $N$. ningerense and $N$. macroclavatum. Its conidia are smaller than those of $N$. macroclavatum and conidia have not been observed in $N$. ningerense. Neofusicoccum magniconidium grows optimally at $25^{\circ} \mathrm{C}$, which is different to $N$. ningerense that grows best at $30^{\circ} \mathrm{C}$.

Type: China: YunNan Province, HongHe Region, PingBian County (GPS $23^{\circ} 08^{\prime} 02^{\prime \prime} \mathrm{N}, 103^{\circ} 32^{\prime} 29^{\prime \prime} \mathrm{E}$ ), from twigs of one E. urophylla $\times E$. grandis tree, 14 November 2014, S.F. Chen \& G.Q. $L i$, fruiting structures induced on needles of Pinus sp. on water agar (HMAS255722 holotype, CSF5876 = CGMCC3.20077 - ex-type culture).

Description: Sexual state unknown. Conidiomata pycnidial, produced on pine needles on WA medium within 4-6 wk., globose to ovoid, dark brown to black, up to $1224 \mu \mathrm{m}$ wide, $774 \mu \mathrm{m}$ high, embedded in needle tissue, semi-immersed to superficial, unilocular, with a central ostiole. Conidiophores reduced to conidiogenous cells. Conidiogenous cells holoblastic, discrete, hyaline, cylindrical to lageniform, phialidic with periclinal thickening, $(8.5-) 10-14.5(-16.5) \times 2.5-3.5(-4) \quad \mu \mathrm{m}$. Paraphyses not seen. Conidia hyaline, thin-walled, smooth with granular contents, unicellular, aseptate narrowly fusiform, base subtruncate to bluntly rounded, (27-)27.5-30(-34) $\times$ (5.5-)6-7.5(-8) $\mu \mathrm{m}$ (av. of 100 conidia $29.1 \times 6.7 \mu \mathrm{m}$; $\mathrm{L} / \mathrm{W}=4.3)$ (Table 5).

Culture characteristics: Colonies on MEA medium with fluffy mycelia, uneven margins and a few cottony aerial mycelia reaching to the lids of Petri plates, mycelial mat appressed, sparse to moderately dense. Colony mycelia initially white, becoming pale mouse grey $\left(15^{\prime \prime \prime} \mathrm{d}\right)$ to mouse grey $\left(13^{\prime \prime \prime} \mathrm{i}\right)$ at the surface and olivaceous grey $\left(23^{\prime \prime \prime \prime} \mathrm{b}\right)$ to iron grey $\left(23^{\prime \prime \prime \prime} \mathrm{k}\right)$ at the reverse after $10 \mathrm{~d}$. Optimal growth temperature $25^{\circ} \mathrm{C}$. No growth at $5{ }^{\circ} \mathrm{C}$ and $40^{\circ} \mathrm{C}$. After $4 \mathrm{~d}$, colonies at $10^{\circ} \mathrm{C}, 15^{\circ} \mathrm{C}, 20^{\circ} \mathrm{C}, 25^{\circ} \mathrm{C}, 30^{\circ} \mathrm{C}$ and $35^{\circ} \mathrm{C}$ reaching 22 $\mathrm{mm}, 50 \mathrm{~mm}, 68 \mathrm{~mm}, 87 \mathrm{~mm}, 82 \mathrm{~mm}$ and $11 \mathrm{~mm}$, respectively.

Host: E. urophylla $\times$ E. grandis.

Distribution: Currently known only from HongHe Region in YunNan Province, China.

Notes - Neofusicoccum magniconidium is phylogenetically closely related to $N$. ningerense and $N$. macroclavatum, but conidia (Table 5) of $N$. magniconidium (av. $29.1 \times 6.7 ; \mathrm{L} / \mathrm{W}=4.3)$ are smaller than those of $N$. macroclavatum (av. $30.3 \times 7.1, \mathrm{~L} / \mathrm{W}=4.2$; Burgess et al. 2005). Neofusicoccum ningerense could not be induced to sporulate in culture. Conidia of $N$. macroclavatum are occasionally 1-4-septate when mature before germination, and spermatia have been observed in this species (Burgess et al. 2005); characters not observed in $N$. magniconidium.

Additional specimens examined: China: YunNan Province, HongHe Region, PingBian County (GPS $23^{\circ} 08^{\prime} 02^{\prime \prime} \mathrm{N}$, $\left.103^{\circ} 32^{\prime} 29^{\prime \prime} \mathrm{E}\right)$, from twigs on one E. urophylla $\times E$. grandis tree, 14 November 2014, S.F. Chen \& G.Q. Li, fruiting structures induced on needles of Pinus sp. on water agar (HMAS255723, culture CSF5875 = CGMCC3.20076).

Neofusicoccum ningerense G.Q. Li \& S.F. Chen, sp. nov.

MycoBank MB834105. (Fig. 8).

Etymology: Name refers to the NingEr County where the fungus was isolated for the first time.

Diagnosis: Neofusicoccum ningerense is closely related to $N$. magniconidium, but differs from the latter species at two bases in each of the ITS, tub2 and $r p b 2$ loci. The optimal growth temperature for $N$. ningerense is also different from that of $N$. magniconidium.

Type: China: YunNan Province, PuEr Region, NingEr County (GPS $23^{\circ} 05^{\prime} 26^{\prime \prime} \mathrm{N}, 102^{\circ} 02^{\prime} 40^{\prime \prime} \mathrm{E}$ ), from twigs of one E. urophylla $\times E$. grandis tree, 16 November 2014, S.F. Chen \& G.Q. Li, dried 30-day-old culture grown on $2 \%$ MEA at $25^{\circ} \mathrm{C}$ (HMAS255724 - holotype, CSF6028 = CGMCC3.20078 - ex-type culture).

Description: Sexual state unknown. Conidiomata-like structures produced on pine needles on WA medium within 4-6 wk., embedded in needle tissue, unilocular (Fig. $8 \mathrm{a}-\mathrm{c}$ ). No conidiophores, conidiogenous cells or conidia have been observed.

Culture characteristics: Colonies on MEA medium with fluffy mycelia, uneven margins and a few cottony aerial mycelia reaching to the lids of Petri plates, mycelial mat appressed, sparse to moderately dense. Colony mycelia initially white, becoming pale mouse grey $\left(15^{\prime \prime \prime \prime} \mathrm{d}\right)$ to mouse grey $\left(13^{\prime \prime \prime} \mathrm{i}\right)$ at the surface and olivaceous grey $\left(23^{\prime \prime \prime \prime} \mathrm{b}\right)$ to iron grey $\left(23^{\prime \prime \prime \prime} \mathrm{k}\right)$ at the reverse after $10 \mathrm{~d}$. Optimal growth temperature is $30^{\circ} \mathrm{C}$, covering the $90 \mathrm{~mm}$ plates after $4 \mathrm{~d}$. No growth at $5^{\circ} \mathrm{C}$ and $40^{\circ} \mathrm{C}$. After $4 \mathrm{~d}$, colonies at $10^{\circ} \mathrm{C}, 15^{\circ} \mathrm{C}, 20^{\circ} \mathrm{C}, 25^{\circ} \mathrm{C}$, $30^{\circ} \mathrm{C}$ and $35^{\circ} \mathrm{C}$ reached $23 \mathrm{~mm}, 53 \mathrm{~mm}, 69 \mathrm{~mm}, 88 \mathrm{~mm}$, $90 \mathrm{~mm}$ and $10 \mathrm{~mm}$, respectively.

Host: $E$. urophylla $\times$ E. grandis.

Distribution: Currently known only from the PuEr Region in YunNan Province, China.

Notes: Only conidiomata were observed in this fungus, and no other asexual structures were observed. Different methods were used in an attempt to induce sporulation but all of these failed. Neofusicoccum 


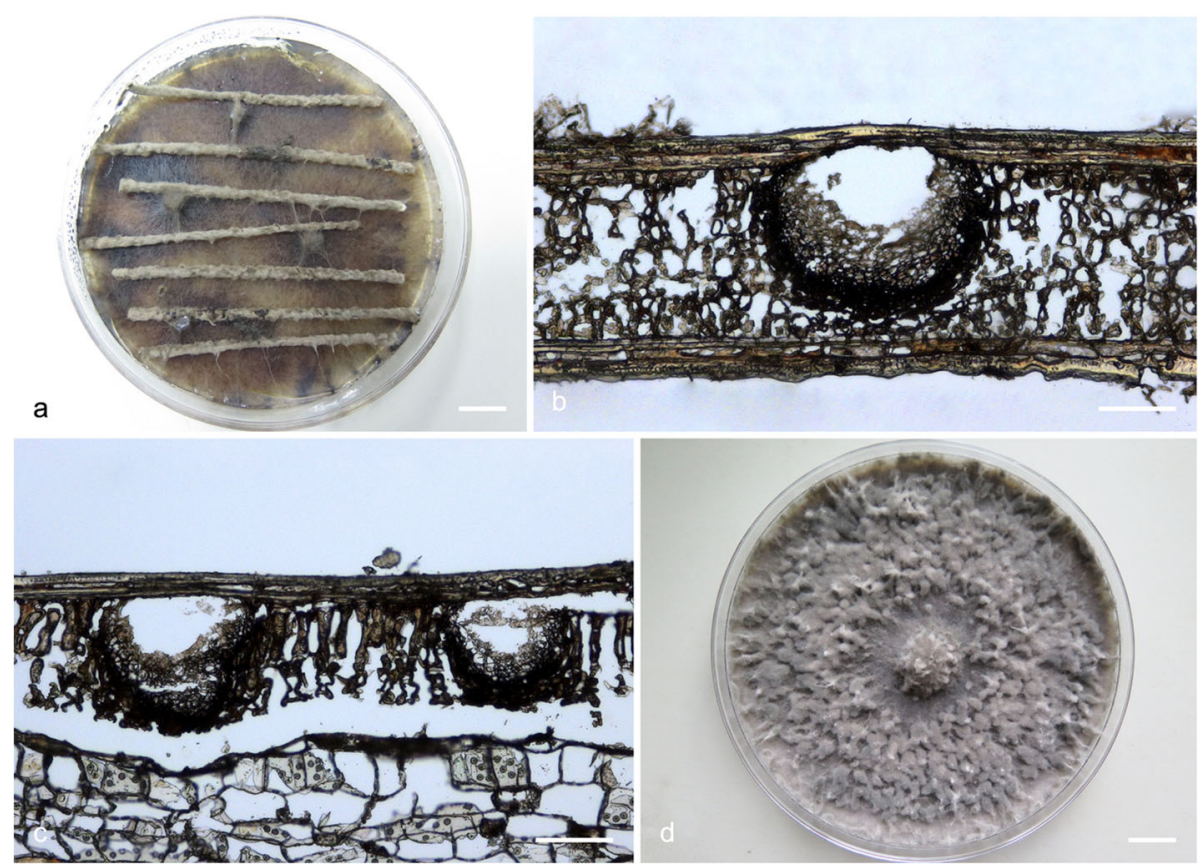

Fig. 8 Neofusicoccum ningerense. a. WA plate with pine needle to induce sporulation; b, c. Longitudinal section through conidiomata-like structure; $\mathbf{d}$. Living culture after $10 \mathrm{~d}$ on $2 \%$ MEA (front). Scale bars: $a, d=1 \mathrm{~cm} ; \mathrm{b}, \mathrm{c}=100 \mu \mathrm{m}$

ningerense is phylogenetically closely related to $N$. magniconidium (Fig. 4). The optimal growth temperature of $N$. ningerense $\left(30^{\circ} \mathrm{C}\right)$ differs from that of $N$. magniconidium $\left(25^{\circ} \mathrm{C}\right)$.

Additional specimens examined: China: YunNan Province, PuEr Region, NingEr County (GPS 2305'26"N, $102^{\circ} 02^{\prime} 40^{\prime \prime}$ ), 16 November 2014, S.F. Chen \& G.Q. Li, from twigs of one E. urophylla $\times E$. grandis tree, dried 30-day-old culture grown on $2 \%$ MEA at $25{ }^{\circ} \mathrm{C}$ (HMAS255725, culture CSF6030 = CGMCC3.20079).

Neofusicoccum parviconidium G.Q. Li \& S.F. Chen, sp. nov.

MycoBank MB834106. (Fig. 9).

Etymology: Name refers to the small conidia in this fungus.

Diagnosis: Neofusicoccum parviconidium can be distinguished from other Neofusicoccum species by its exceptionally short conidia.

Type: China: YunNan Province, HongHe Region, PingBian County (GPS 2300'52 "N, 103³8'09"E), from twigs of one Eucalyptus tree, 13 November 2014, S.F. Chen \& G.Q. $L i$, fruiting structures induced on needles of Pinus sp. on water agar (HMAS255726 - holotype, CSF5667 = CGMCC3.20074 - ex-type culture).
Description: Sexual state unknown. Conidiomata pycnidial, produced on pine needles on WA medium within 4-6 wk., globose to ovoid, dark brown to black, up to $604 \mu \mathrm{m}$ wide, $1205 \mu \mathrm{m}$ high, embedded in needle tissue, semi-immersed to superficial, unilocular, with a central ostiole. Conidiophores reduced to conidiogenous cells. Conidiogenous cells holoblastic, discrete, hyaline, cylindrical to lageniform, phialidic with periclinal thickening, (5.5-)7-15(-20) ×2-2.5(-3) $\mu \mathrm{m}$. Paraphyses not seen. Conidia hyaline, thin-walled, smooth with granular contents, unicellular, aseptate ellipsoid to fusoid, base subtruncate to bluntly rounded, (9.5-)10.5-11.5(-12.5) $\times$ (4.4-)5-5.5(-6) $\mu \mathrm{m}$ (av. of 100 conidia $10.9 \times 5.2 \mu \mathrm{m}$; $\mathrm{L} / \mathrm{W}=2.1)$ (Table 5).

Culture characteristics: Colonies on MEA medium with fluffy mycelia, uneven margins and a few cottony aerial mycelia reaching to the lids of Petri plates, mycelial mat appressed, sparse to moderately dense. Colony mycelia initially white, becoming smoke grey $\left(21^{\text {" }} \mathrm{f}\right)$ to pale mouse grey $\left(15^{\prime \prime \prime \prime} \mathrm{d}\right)$ at the surface and olivaceous (21"k) to iron grey $\left(23^{\prime \prime \prime \prime} \mathrm{k}\right)$ at the reverse after $10 \mathrm{~d}$. Optimal growth temperature $30^{\circ} \mathrm{C}$. No growth at $5{ }^{\circ} \mathrm{C}$ and $40^{\circ} \mathrm{C}$. After $4 \mathrm{~d}$, colonies at $10^{\circ} \mathrm{C}, 15^{\circ} \mathrm{C}, 20^{\circ} \mathrm{C}, 25^{\circ} \mathrm{C}$, $30{ }^{\circ} \mathrm{C}$ and $35^{\circ} \mathrm{C}$ reaching $16 \mathrm{~mm}, 39 \mathrm{~mm}, 55 \mathrm{~mm}, 74$ $\mathrm{mm}, 85 \mathrm{~mm}$ and $29 \mathrm{~mm}$, respectively.

Host: Eucalyptus sp.

Distribution: Currently only known from HongHe Region in YunNan Province, China. 

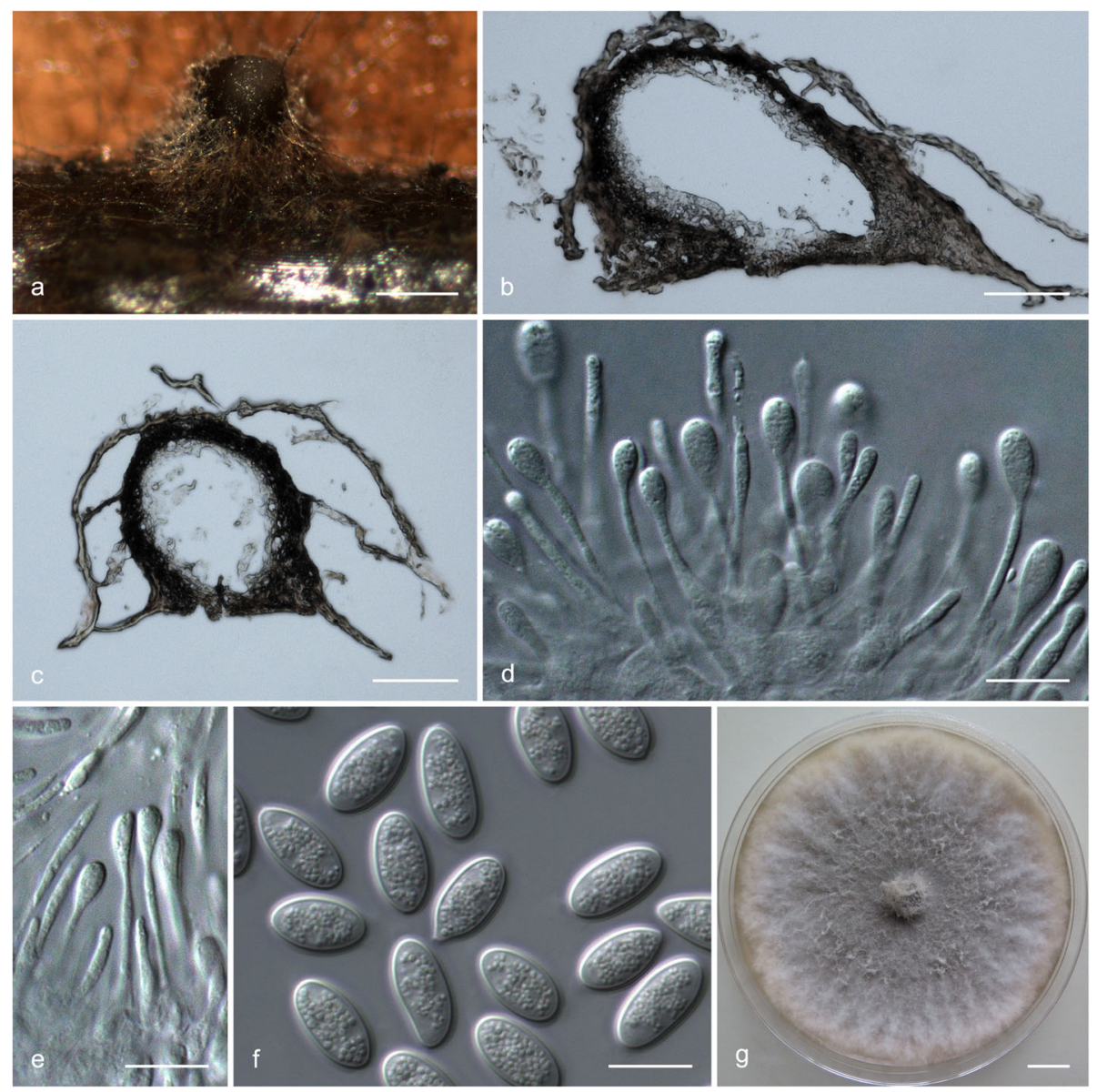

Fig. 9 Neofusicoccum parviconidium. a. Conidioma formed on pine needle culture; b, c. Longitudinal section through conidioma; $\mathbf{d}$, e. Conidiogenous cells and developing conidia; f. Conidia; $\mathbf{g}$. Living culture after $10 \mathrm{~d}$ on $2 \%$ MEA (front). Scale bars: $\mathrm{a}=500 \mu \mathrm{m} ; \mathrm{b}, \mathrm{c}=100 \mu \mathrm{m} ; \mathrm{d}-\mathrm{f}=10 \mu \mathrm{m} ; \mathrm{g}=1 \mathrm{~cm}$

Notes: Neofusicoccum parviconidium is phylogenetically closely related to $N$. mangiferae and $N$. microconidium (Fig. 4), but conidia (Table 5) of N. parviconidium (av. $10.9 \times 5.2 ; \mathrm{L} / \mathrm{W}=2.1$ ) are smaller than those of $N$. mangiferae (av. $13.6 \times 5.4 ; \mathrm{L} / \mathrm{W}=2.0-2.5$; Slippers et al. 2005), shorter and wider than those of $N$. microconidium (av. $12.3 \times 5.0 ; \mathrm{L} / \mathrm{W}=2.5$; Li et al. 2018).

Additional specimens examined: China: YunNan Province, HongHe Region, PingBian County (GPS 2300' $52^{\prime \prime} \mathrm{N}$, $\left.103^{\circ} 38^{\prime} 09^{\prime \prime} \mathrm{E}\right)$, from twigs on one Eucalyptus tree, 13 November 2014, S.F. Chen \& G.Q. Li, fruiting structures induced on needles of Pinus sp. on water agar (HMAS255727, culture CSF5677 = CGMCC3.20085); YunNan Province, HongHe Region, PingBian County (GPS $23^{\circ} 00^{\prime} 52^{\prime \prime} \mathrm{N}, 103^{\circ} 38^{\prime} 09^{\prime \prime} \mathrm{E}$ ), from twigs of one Eucalyptus tree, 13 November 2014, S.F. Chen \& G.Q. Li (culture CSF5670); YunNan Province, HongHe Region, PingBian County (GPS $23^{\circ} 00^{\prime} 52^{\prime \prime} \mathrm{N}, 103^{\circ} 38^{\prime} 09^{\prime \prime} \mathrm{E}$ ), from twigs of one Eucalyptus tree, 13 November 2014, S.F. Chen \& G.Q. Li (culture CSF5681).
Neofusicoccum yunnanense G.Q. Li \& S.F. Chen, sp. nov.

MycoBank MB834107. (Fig. 10).

Etymology: Name refers to the YunNan Province where the fungus was isolated for the first time.

Diagnosis: Neofusicoccum yunnanense resides in ' $N$. parvum / N. ribis' complex and has smaller conidia than its closest relatives, $N$. algeriense, $N$. dianense, $N$. italium and $N$. parvum, yet longer than those of $N$. hongkongense. Neofusicoccum yunnanense grew optimally at $30^{\circ} \mathrm{C}$, which is different from that of $N$. algeriense $\left(25^{\circ} \mathrm{C}\right), N$. dianense $\left(25^{\circ} \mathrm{C}\right)$ and $N$. hongkongense $\left(25^{\circ} \mathrm{C}\right)$. Data for growth in culture are not available for $N$. italium or N. parvum.

Type: China: YunNan Province, ChuXiong Region, LuFeng County (GPS 2503'12"N, 101 $46^{\prime} 29^{\prime \prime}$ ), from twigs of one E. globulus tree, 19 November 2014, S.F. 


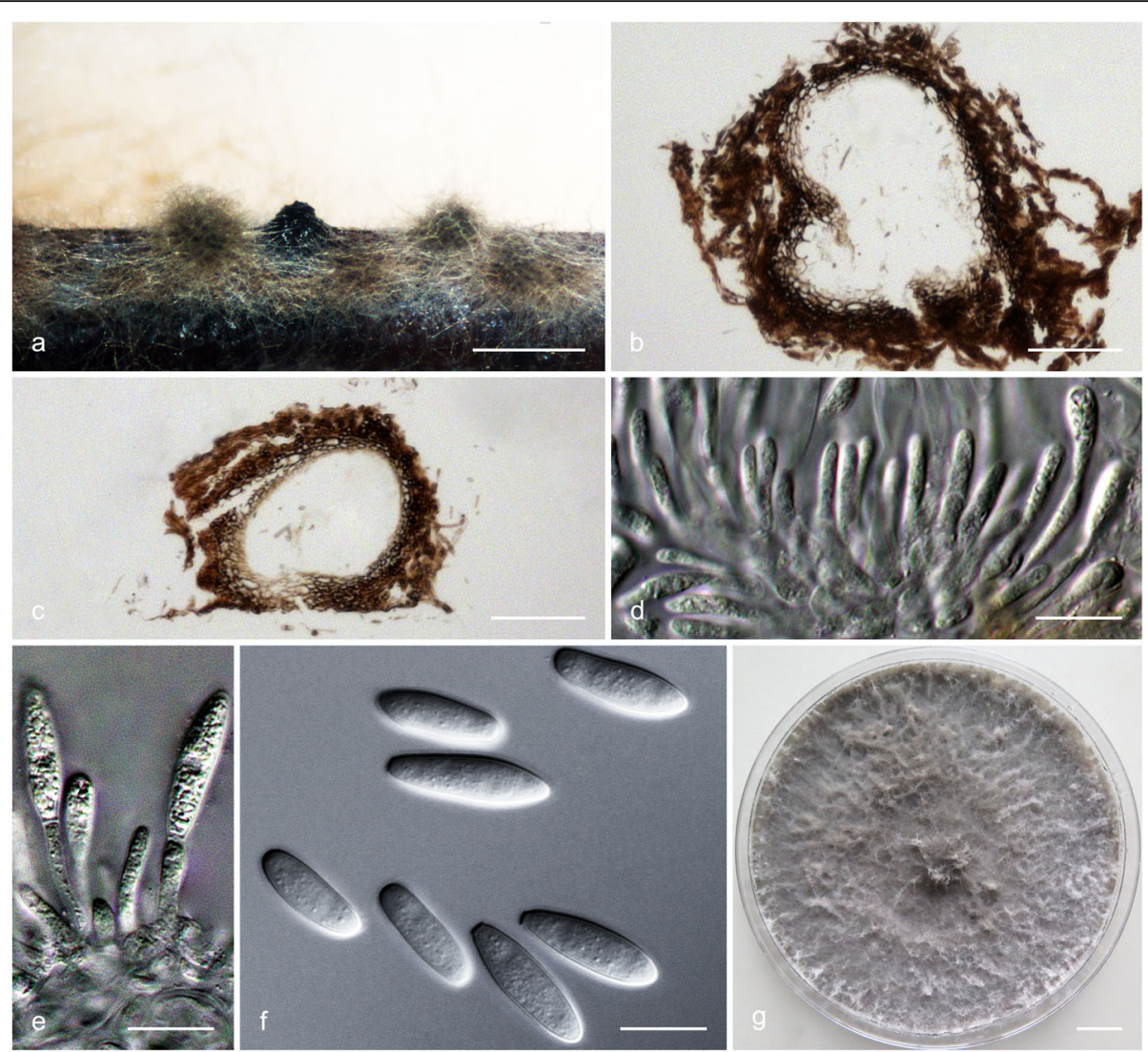

Fig. 10 Neofusicoccum yunnanense. a. Conidiomata formed on pine needle culture; b, c. Longitudinal section through conidioma; $\mathbf{d}$, e. Conidiogenous cells and developing conidia; $\mathbf{f}$. Conidia; $\mathbf{g}$. Living culture after $10 \mathrm{~d}$ on 2\% MEA (front). Scale bars: $\mathrm{a}=500 \mu \mathrm{m} ; \mathrm{b}, \mathrm{c}=100 \mu \mathrm{m} ; \mathrm{d}-\mathrm{f}=10 \mu \mathrm{m} ; \mathrm{g}=1 \mathrm{~cm}$

Chen \& G.Q. Li, fruiting structures induced on needles of Pinus sp. on water agar (HMAS255728 - holotype, CSF6142 = CGMCC3.20083 - ex-type culture).

Description: Sexual state unknown. Conidiomata pycnidial, produced on pine needles on WA medium within 4-6 wk., globose to ovoid, dark brown to black, up to $982 \mu \mathrm{m}$ wide, $549 \mu \mathrm{m}$ high, embedded in needle tissue, semi-immersed to superficial, unilocular, with a central ostiole. Conidiophores reduced to conidiogenous cells. Conidiogenous cells holoblastic, discrete, hyaline, cylindrical to lageniform, phialidic with periclinal thickening, (10.5-)11-15(-18.5) × (1.5-)2-2.5(-3) $\mu \mathrm{m}$. Paraphyses not seen. Conidia hyaline, thin-walled, smooth with granular contents, unicellular, aseptate narrowly fusiform, base subtruncate to bluntly rounded, (13-)13.5$17.5(-20) \times(3.5-) 4-4.5(-5) \quad \mu \mathrm{m}$ (av. of 100 conidia $15.6 \times 4.4 \mu \mathrm{m} ; \mathrm{L} / \mathrm{W}=3.5)($ Table 5$)$.

Culture characteristics: Colonies on MEA medium with fluffy mycelia, uneven margins and a few cottony aerial mycelia reaching the lids of Petri plates, mycelial mats appressed and sparse to moderately dense. Colony mycelia initially white, becoming pale mouse grey $\left(15^{\prime \prime \prime \prime} d\right)$ to mouse grey $\left(13^{\prime \prime \prime} i\right)$ at the surface and olivaceous grey (23"'"b) to iron grey $\left(23^{\prime \prime \prime} \mathrm{k}\right)$ at the reverse after $10 \mathrm{~d}$. Optimal growth temperature $30^{\circ} \mathrm{C}$, covering the $90 \mathrm{~mm}$ plates after 4 d. No growth at $5{ }^{\circ} \mathrm{C}$ and $40^{\circ} \mathrm{C}$. After $4 \mathrm{~d}$, colonies at $10{ }^{\circ} \mathrm{C}, 15^{\circ} \mathrm{C}, 20^{\circ} \mathrm{C}, 25^{\circ} \mathrm{C}, 30^{\circ} \mathrm{C}$ and $35^{\circ} \mathrm{C}$ reaching $13 \mathrm{~mm}, 42 \mathrm{~mm}, 64 \mathrm{~mm}, 86 \mathrm{~mm}, 90 \mathrm{~mm}$ and $16 \mathrm{~mm}$, respectively.

Host: E. globulus, E. urophylla $\times$ E. grandis and Eucalyptus sp.

Distribution: Currently known from ChuXiong, HongHe, KunMing, PuEr, WenShan and YuXi Regions in YunNan Province, China.

Notes: Neofusicoccum yunnanense is phylogenetically closely related to $N$. algeriense, $N$. dianense, $N$. hongkongense, N. italium and N. parvum (Fig. 4). Conidia of $N$. yunnanense (av. $15.6 \times 4.4 ; \mathrm{L} / \mathrm{W}=3.5$ ) are smaller than those of $N$. algeriense (av. $17.6 \times 5.6 ; \mathrm{L} /$ $\mathrm{W}=3.1$; Berraf-Tebbal et al. 2014), $N$. dianense (av. $18.9 \times 5.2 ; \mathrm{L} / \mathrm{W}=3.6$ ), $N$. italium (av. $15.8 \times 5.2 ; \mathrm{L} /$ $\mathrm{W}=3.0$; Marin-Felix et al. 2017) and N. parvum (av. $17.1 \times 5.5 ; \mathrm{L} / \mathrm{W}=3.2$; Phillips et al. 2013) and longer than those of $N$. hongkongense (av. $14.1 \times 4.7 ; \mathrm{L} / \mathrm{W}=$ 3.0; Li et al. 2018). 
Additional specimens examined: China: YunNan Province, PuEr Region, NingEr County (GPS 230 $5^{\prime} 26^{\prime \prime} \mathrm{N}$, $\left.102^{\circ} 02^{\prime} 40^{\prime \prime} \mathrm{E}\right)$, from twigs of one $E$. urophylla $\times E$. grandis tree, 16 November 2014, S.F. Chen \& G.Q. Li, fruiting structures induced on needles of Pinus sp. on water agar (HMAS255729, culture CSF6034=CGMC C3.20080); YunNan Province, HongHe Region, PingBian County (GPS 2304'02"N, 103 $36^{\prime} 33^{\prime \prime} \mathrm{E}$ ), from twigs of one Eucalyptus tree, 13 November 2014, S.F. Chen \& G.Q. Li (culture CSF5686); YunNan Province, KunMing Region, AnNing County (GPS 24 $55^{\prime} 02^{\prime \prime} \mathrm{N}, 102^{\circ} 23^{\prime} 41^{\prime \prime}$ E), from twigs of one E. globulus tree, 19 November 2014, S.F. Chen \& G.Q. Li (culture CSF6169).

\section{Distribution of Botryosphaeriaceae in YunNan Province}

Based on phylogenetic and morphological analyses, eleven species were identified from collections in YunNan Province. Of these, Neofusicoccum yunnanense (31.3\%) was the most prevalent species, followed by $N$. parvum (25.3\%), B. wangensis (19.9\%), B. fusispora (10.8\%), N. parviconidium (4.8\%), $N$. dianense (3.0\%), L. pseudotheobromae (1.2\%), N. magniconidium (1.2\%), N. ningerense (1.2\%), B. puerensis (0.6\%) and N. kwambonambiense (0.6\%) (Fig. 11b). Neofusicoccum yunnanense was detected in all six regions surveyed, B. wangensis was found in all regions other than $\mathrm{PuEr}, N$. parvum was found in all regions other than ChuXiong, B. fusispora was found in the ChuXiong, HongHe, PuEr and YuXi Regions, and the other species were found in one or two regions of YunNan (Fig. 11c).

Sampling sites in this study included four distinct climate types. Samples in ChuXiong (Region A), KunMing (Region B) and WenShan (Region F) Regions were from the northern sub-tropical or central sub-tropical zone; samples in HongHe (Region E), PuEr (Region D) and YuXi (Region C) were from the southern sub-tropical or tropical zone. Four species were detected in all four climate types surveyed and these included B. fusispora, B. wangensis, N. parvum and $N$. yunnanense. The remaining seven species identified in this study were detected in only southern sub-tropical or tropical zone (Fig. 11a, c).

\section{Pathogenicity tests}

Based on their ITS, tef1 and tub2 genotypes, thirty-six isolates of the Botryosphaeriaceae in three genera and representing 11 species were selected for inoculation. Typical lesions were observed on inoculated Eucalyptus plants and lesion lengths were recorded one month after inoculation. The results of pathogenicity tests showed that all isolates produced lesions on the test plants, while the controls produced only small zones of wound reaction (Fig. 12, Additional file 1: Figure S1). The inoculated species were re-isolated from the lesions, but never from the negative controls. Consequently, Koch's postulates were fulfilled.

Lesion length data were not normally distributed based on Kolmogorov-Smirnov normality test $(P<0.05)$. All data were consequently transformed (Kolmogorov-Smirnov normality test, $P=0.2$ ) by conducting a Rank transformation using the statistical package SPSS v. 20.

On E. globulus and E. urophylla $\times$ E. grandis, the shortest lesions were produced by isolate CSF5802 of L. pseudotheobromae and isolate CSF6178 of B. fusispora (Fig. 12). Results of the one-way ANOVA showed that some isolates produced lesions significantly longer than those caused by isolate CSF5802 on E. globulus and isolate CSF6178 on E. urophylla $\times E$. grandis $(P=0.05)$. These isolates included CSF5820 (B. wangensis), CSF6050 ( $L$. pseudotheobromae), CSF5721 and CSF6075 ( $N$. dianense), CSF6037 (N. kwambonambiense), CSF5875 (N. magniconidium), CSF6028 and CSF6030 (N. ningerense), CSF5667, CSF5677 and CSF5681 (N. parviconidium), CSF5782 and CSF6038 (N. parvum), CSF5706, CSF5974 and CSF6034 (N. yunnanense) as shown in Fig. 12. Of these, the most aggressive isolate was CSF6050 (L. pseudotheobromae), which produced the longest lesions on E. urophylla $\times E$. grandis $(70.80 \pm 7.17 \mathrm{~mm})$ and E. globulus $(58.00 \pm 8.34$ $\mathrm{mm})$ as shown in Fig. 12.

Results of GLM Univariate Analysis (two-way ANOVA) showed a significant $(P=0.001)$ interaction effect between isolate and host. The analyses also showed that not all isolates of the same species of Botryosphaeriaceae reacted in the same manner on the tested $E$. urophylla $\times E$. grandis clone or E. globulus plants. For example, lesions produced by isolate CSF5802 (L. pseudotheobromae) on E. urophylla $\times$ E. grandis were significantly longer than those on E. globulus, while the lesion lengths produced by isolate CSF6050 (L. pseudotheobromae) on the two tested Eucalyptus genotypes were not significantly different $(P=0.05)$. The results also showed that the pathogenicity of isolates of the same species on the two tested Eucalyptus genotypes can be different. For example, lesion lengths produced by isolate CSF5820 (B. wangensis) on E. urophylla $\times$ E. grandis and E. globulus were significantly longer than the other isolates of this species $(P=0.05)$ (Fig. 12). In contrast, lesion lengths produced by all isolates of $B$. fusispora on both E. urophylla $\times$ $E$. grandis and E. globulus were not significantly different $(P=0.05)$ from each other (Fig. 12).

For the tested isolates residing in three genera of the Botryosphaeriaceae, the overall data showed that species of Lasiodiplodia were the most aggressive, followed by those in Neofusicoccum (Fig. 12). The overall data also showed that plants of the E. urophylla $\times$ E. grandis clone and E. globulus seed-derived plants had similar levels of susceptibility to most of the tested isolates (Fig. 12). The exceptions were for isolates CSF5802 ( $L$. 


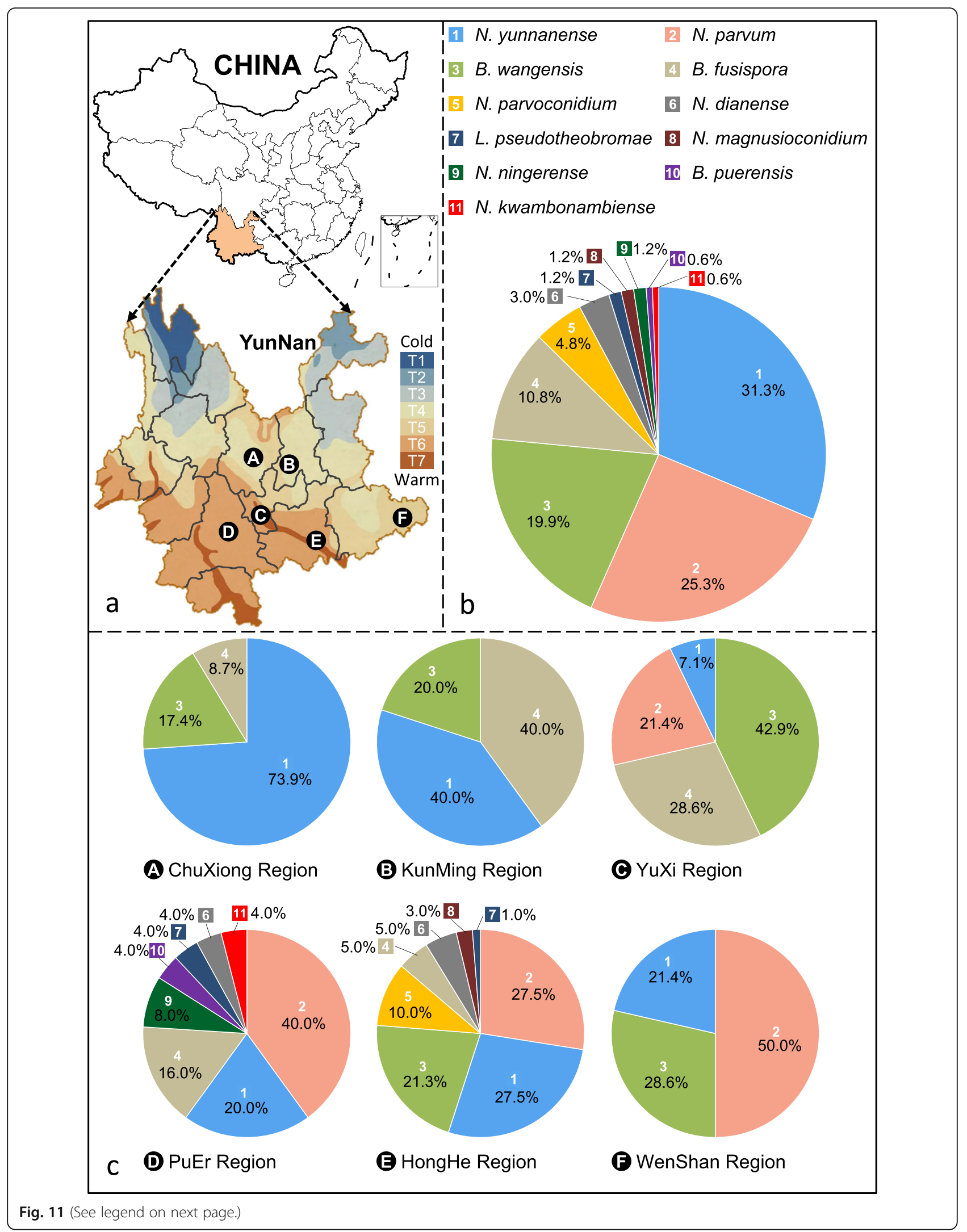


(See figure on previous page.)

Fig. 11 Botryosphaeriaceae species detected from Eucalyptus plantations in six regions in YunNan Province. a. Sampling regions across different climatic zones. T1: cold highland zone, T2: central temperate zone, T3: southern temperate zone, T4: northern sub-tropical zone, T5: central sub-tropical zone, T6: southern sub-tropical zone, T7: tropical zone; b. Prevalence of Botryosphaeriaceae species as a percentage of the total isolates in YunNan Province. Different species are represented by numbers with different colours; $\mathbf{c}$. Prevalence of Botryosphaeriaceae species as a percentage of the total isolates in each of the different sampling regions

pseudotheobromae), CSF5722 (N. dianense), CSF6028 ( $N$. ningerense), and CSF5974 (N. yunnanense), where the lesions were significantly different on the E. urophylla $\times$ E. grandis clone and the E. globulus plants.

\section{DISCUSSION}

In this study, 166 isolates of the Botryosphaeriaceae were characterized from Eucalyptus plantations in six regions of the YunNan Province. Eleven species residing in the three genera Botryosphaeria, Lasiodiplodia and Neofusicoccum were identified. These included Botryosphaeria fusispora, B. wangensis, Lasiodiplodia pseudotheobromae, Neofusicoccum kwambonambiense, N. parvum, and six novel species described here as $B$. puerensis, $N$. dianense, $N$. magniconidium, $N$. ningerense, $N$. parviconidium and N. yunnanense.

Analysis of multi-gene phylogenetic concordance has emerged as standard practice for species identification in the Botryosphaeriaceae (Phillips et al. 2013; Chen et al. 2014a, 2014b; Slippers et al. 2017; Yang et al. 2017; Li et al. 2018; Jayawardena et al. 2019a, 2019b; Phillips et al. 2019). This approach was also essential in the present study to distinguish between closely related species, where we considered the phylogenetic signal for four loci, including ITS, tef1, tub2 and $r p b 2$. The most common loci used for species delineation in Botryosphaeria are ITS, tef1 and tub2 (Phillips et al. 2013; Chen et al. 2014a, 2014b; Osorio et al. 2017; Li et al. 2018) and in Lasiodiplodia and Neofusicoccum are ITS, tef1, tub2 and rpb2 (Pavlic et al. 2009a, 2009b; Sakalidis et al. 2011; Cruywagen et al. 2017; Yang et al. 2017; Li et al. 2018; Phillips et al. 2019). These were also the most informative loci for the genera in this study. However, a limitation lies in the fact that there are numerous species for which sequence data are not available for all of these loci.

The majority of the isolates (67\%) obtained in this study were species of Neofusicoccum. Five of these were previously undescribed taxa and these were found in addition to the well-known species $N$. kwambonambiense and $N$. parvum. Together with the newly described species, Neofusicoccum now includes 48 species (Phillips et al. 2013; Yang et al. 2017; Jami et al. 2018; Li et al. 2018).

Neofusicoccum yunnanense was isolated from all six regions in the sub-tropical and tropical zones, suggesting that it has a wide distribution in different climatic zones.
In contrast, the other new species of Neofusicoccum ( $N$. dianense, $N$. magniconidium, $N$. ningerense and $N$. parviconidium) were all from the southern sub-tropical or tropical zone that has relatively high average temperatures. Neofusicoccum parvum was isolated in five sampled regions, while N. kwambonambiense was isolated only from PuEr. A previous study has shown that these two species have a wide geographic distribution including areas, with mediterranean and sub-tropical climates worldwide (Sakalidis et al. 2013), and that they have a wide range of hosts (Pavlic et al. 2009a; Phillips et al. 2013; Sakalidis et al. 2013). In China, N. parvum has also been reported from a wide range of hosts including Cupressus funebris (Li et al. 2010), Eriobotrya japonica (Zhai and Zhang 2019), Eucalyptus spp. (Chen et al. 2011), Koelreuteria paniculata (Fang et al. 2019), Hevea brasiliensis (Liu et al. 2017) and Juglans regia (Yu et al. 2015) and in these cases, from sub-tropical and tropical zones. Neofusicoccum kwambonambiense was first reported from Syzygium cordatum (Myrtaceae) in South Africa (Pavlic et al. 2009a). The present study represents the first report of this species associated with Eucalyptus and also the Myrtaceae in China.

Two new cryptic species (N. dianense and N. yunnanense) were discovered in the ' $N$. parvum / N. ribis' complex based on concordance in the phylogenetic analyses of the ITS, tef1, tub2 and rpb2 datasets in this study. Cryptic species are defined as two or more distinct species often treated as a single species because they are at least superficially indistinguishable based on their morphology (Bickford et al. 2007). The use of multi-locus phylogenetic concordance has revealed numerous cryptic species in the Botryosphaeriaceae in recent years (Alves et al. 2008; Pavlic et al. 2009b; Phillips et al. 2013; Slippers et al. 2014, 2017; Yang et al. 2017). This is especially true in the ' $N$. parvum / N. ribis' complex, where six cryptic species with similar conidia have been distinguished based on multigene analyses (Pavlic et al. 2009a; Sakalidis et al. 2011; Li et al. 2018). Amongst the three new Neofusicoccum species (N. magniconidium, $N$. ningerense and $N$. parviconidium) discovered in the present study and that reside in the 'N. parvum / N. ribis' complex, N. parviconidium, like $N$. microconidium, have relatively small conidia compared to other species in the genus. Neofusicoccum magniconidium has larger conidia in comparison with those of $N$. macroclavatum, and it is phylogenetically most closely related to $N$. macroclavatum, and $N$. ningerense, the latter of 


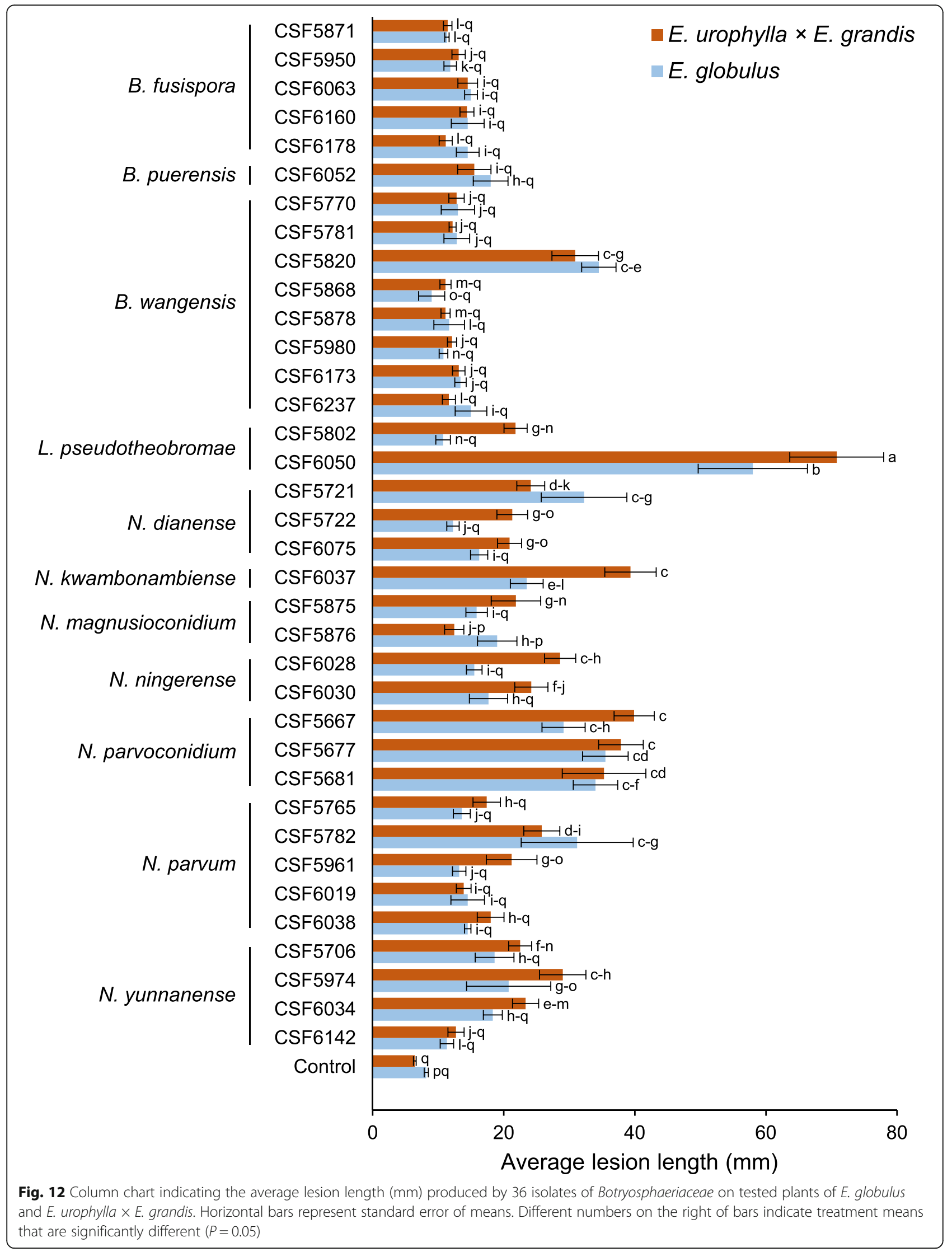


which failed to produce fruiting structures. These newly described species, together with other species in the ' $N$. parvum / N. ribis' complex, makes this one of the most widespread 'lineages' in the Botryosphaeriaceae.

When our results are consolidated with those from previous studies (Chen et al. 2011; Li et al. 2018), a total of nine species of Neofusicoccum have been identified from Eucalyptus plantations in China. These include $N$. dianense, $N$. kwambonambiense, $N$. magniconidium, $N$. microconidium, $N$. ningerense, $N$. parviconidium, $N$. parvum, N. sinoeucalypti and N. yunnanense. Seven of these nine species were first described from or are known only from China on Eucalyptus in plantations. The exceptions are $N$. parvum and $N$. kwambonambiense (Chen et al. 2011, Li et al. 2018). These results suggest an unusually high diversity of Neofusicoccum species in non-native Eucalyptus plantations in China. They could also imply that many additional Neofusicoccum species could exist in yet unsampled regions of the country.

A total of 52 isolates were identified as species of Botryosphaeria, including B. fusispora, B. wangensis and the newly described $B$. puerensis found in this study. The genus Botryosphaeria was first introduced in 1863 by Cesati \& De Notaris, and 143 species were recorded in this genus up to 1997 (Denman et al. 2000). As is true for most groups in the Botryosphaeriaceae, Botryosphaeria has been substantially revised in recent years using a combination of DNA sequence and morphological data. The genus now accommodates 16 species for which clear taxonomic descriptions and DNA sequence data are available (Phillips et al. 2013; Slippers et al. 2014; Xu et al. 2015; Ariyawansa et al. 2016; Zhou et al. 2016, 2017; Li et al. 2018).

Many Botryosphaeria species occur widespread across a broad climatic environment and on diverse hosts. For example, Botryosphaeria fusispora was first described from Entada sp. in Thailand (Chiang Rai, Doi Tung: tropical zone; Liu et al. 2012), and subsequently in the Fulian, GuangDong and GuangXi Provinces in subtropical and tropical zones in China (Li et al. 2018). In the present study, B. fusispora was isolated in four of six sampled regions in the YunNan Province, indicating that this species has a wide distribution in Eucalyptus plantations in sub-tropical and tropical zones. Botryosphaeria wangensis was known only from Cedrus deodara in the HeNan Province in Central China (temperate zone) previously (Li et al. 2018). In contrast, it was detected in five regions (sub-tropical and tropical zones) in YunNan Province in the present study, suggesting that it can also survive at a broad range of temperatures. Many of the other Botryosphaeria species previously described occur in more temperate climates, but this is clearly not a characteristic of the genus.
The newly described B. puerensis is known from only one isolate. It was clearly separate from all other known species based on phylogenetic analyses of tef1, tub2 and $r p b 2$ datasets. Obvious morphological differences were also observed between $B$. puerensis and its closest known sister species. While we recognise that it is preferable to describe new species based on more than one isolate or specimen (Seifert and Rossman 2010), we chose to describe this species because it was well defined and this is not unprecedented in studies of the Botryosphaeriaceae (e.g. Slippers et al. 2014; Yang et al. 2017; Zhang et al. 2017).

Lasiodiplodia pseudotheobromae was identified from Eucalyptus plantations in PuEr and HongHe Regions (tropical zone) in YunNan Province. This species has previously been reported from a wide variety of hosts across many different climate zones globally including Brazil (tropical zone) (Netto et al. 2014), China (subtropical and tropical zones) (Zhao et al. 2010; Li et al. 2018), Costa Rica and Suriname (tropical zone) (Alves et al. 2008), amongst many others. In China, L. pseudotheobromae was first reported in 2010 (Zhao et al. 2010) and recorded from different plant species more recently (Chen et al. 2011; Dissanayake et al. 2015; Li et al. 2015; Tennakoon et al. 2016; Wu et al. 2019). Collectively, these results suggest that $L$. pseudotheobromae is one of the most widespread species in the Botryosphaeriaceae globally and it has at least 105 recorded hosts (NCBI Nucleotide Database, 2019). It is a species that might easily be spread amongst regions and can be expected to have an important impact on a wide variety of plant-based industries in a diversity of environments.

Overall, the results of this study suggest that climate influences the distribution of Botryosphaeriaceae, even over relatively small distances $(560 \mathrm{~km}$ across the widest sampling points in this study). This is despite the obvious adaptability to both hosts and temperature ranges that is reflected in their wide geographic distribution across climates worldwide (Slippers and Wingfield 2007; Slippers et al. 2014). Only three species of Botryosphaeria and one species of Lasiodiplodia were detected in the sub-tropical or tropical zone in YunNan Province, compared to the seven species of Neofusicoccum. A greater number of Botryosphaeriaceae species were detected in the southern sub-tropical or tropical zone (PuEr and HongHe Regions) than northern subtropical or central sub-tropical zone (ChuXiong, KunMing and WenShan Regions), suggesting that climate affects the distribution of species in the Botryosphaeiraceae. Relatively few species were detected from YuXi Region in the sub-tropical or tropical zone, which might have been affected by the lower number of samples collected in this region. Factors that probably 
affect this species diversity and distribution include climates such as temperature and water, host-associated factors such as species and age of host and the host structures from which isolations are made (Slippers et al. 2017; Velásquez et al. 2018).

All 11 species identified in this study were pathogenic to the $E$. urophylla $\times E$. grandis hybrid clone and $E$. globulus seed-derived plants. Some of these species could present threats to the Eucalyptus industry. One isolate of $L$. pseudotheobromae produced significantly longer lesions than those of other genera of Botryosphaeriaceae on the tested Eucalyptus genotypes, which is consistent with the results of previous studies (Pérez et al. 2010; Chen et al. 2011; Li et al. 2018). With the exception of one isolate, isolates of the Botryosphaeria spp. produced the smallest lesions in the pathogenicity tests; a result similar to that of previous studies ( $\mathrm{Li}$ et al. 2018). The species of Neofusicoccum were also pathogenic and produced lesions that were generally larger than those associated with the Botryosphaeria species, which is also consistent with the results of previous studies (Mohali et al. 2009; Pérez et al. 2010; Chen et al. 2011; Li et al. 2018). There was also significant variation in aggressiveness between isolates of species, which emphasises that evaluation of pathogenicity linked to Eucalyptus breeding trials should include isolates covering a broad range of aggressiveness.

The present study provides foundational data on the diversity, distribution and pathogenicity of the Botryosphaeriaceae from Eucalyptus plantations in YunNan Province in southwestern China. Together with previous studies (Chen et al. 2011; Li et al. 2015, 2018), the results revealed a high level of Botryosphaeriaceae diversity associated with diseased Eucalyptus in the sampled plantations. Special attention should be afforded in future monitoring, to species with wide distributions and high levels of aggressiveness to species of Eucalyptus.

\section{CONCLUSIONS}

This study provides important new data regarding on the diversity, distribution and pathogenicity of the Botryosphaeriaceae from Eucalyptus plantations in YunNan Province in southwestern China. Results revealed a high level of Botryosphaeriaceae diversity associated with diseased Eucalyptus in the sampled plantations. Species diversity and composition changed across the different climatic zones, despite their relatively close proximity and the fact that some of the species have a global distribution. All the Botryosphaeriaceae species were pathogenic to tested oneyear-old Eucalyptus plants, but showed significant inter- and intra-species variation in aggressiveness amongst isolates. Future tree disease monitoring should consider Botryosphaeriaceae species with wide distributions and high levels of aggressiveness to species of Eucalyptus. The study also provides a foundation for monitoring and management of Botryosphaeriaceae through selection and breeding of Eucalyptus in the YunNan Province in southwestern China.

\section{Supplementary information}

Supplementary information accompanies this paper at https://doi.org/10. 1186/s43008-020-00043-x.

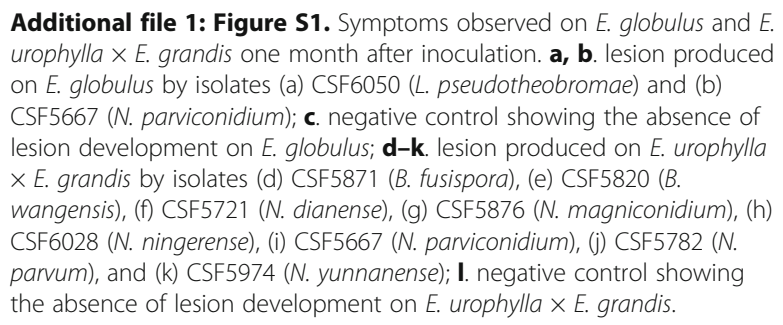

\section{Acknowledgements}

We thank Ms. JieQiong Li, Mr. ShengLong Zhang and Mr. ChengJie Zhao for their assistance in collecting samples. We also appreciate the support of Ms. QianLi Liu and Ms. Wen Wang in conducting pathogenicity tests.

\section{Adherence to national and international regulations}

Not applicable to the specific isolates used in this manuscript. All isolates are maintained in culture collections as per government regulations and quarantine specifications.

\section{Authors' contributions}

G.Q. Li collected samples, conducted experiments, analysed the data and wrote the first draft of the manuscript, B. Slippers and M.J. Wingfield advised the project and assisted in writing the manuscript, S.F. Chen designed the research, collected samples, evaluated the results and contributed to writing the manuscript. The authors read and approved the final manuscript.

\section{Funding}

This study was supported by the National Key R\&D Program of China (project no. 2016YFD0600505), the National Natural Science Foundation of China (NSFC) (project no. 31622019 and 31400546), the Guangdong Provincial Science and Technology Project (project no: 2017A030303024), the Top Young Talents Program in National Special Support Program for High-level Talents of China (Ten-thousand Talents Program) (project no. W03070115) and the Top Young Talents Program in Science and Technology of Guangdong Special Support Program in China (project no. 2017TQ04N764)

\section{Availability of data and materials}

All data generated or analysed during this study are included in this published article [and its supplementary information files].

Ethics approval and consent to participate

Not applicable, no humans, human subjects nor data were used in this study.

Consent for publication

Not applicable.

\section{Competing interests}

The authors declare that they have no competing interests.

\section{Author details}

${ }^{1}$ State Key Laboratory of Tree Genetics and Breeding (SKLTGB), Chinese Academy of Forestry (CAF), Haidian District, Beijing 100091, China.

${ }^{2}$ Department of Biochemistry, Genetics and Microbiology, Forestry and 
Agricultural Biotechnology Institute (FABI), University of Pretoria, Pretoria 0028, South Africa. ${ }^{3}$ China Eucalypt Research Centre (CERC), Chinese Academy of Forestry (CAF), ZhanJiang 524022, GuangDong Province, China.

Received: 20 February 2020 Accepted: 1 September 2020 Published online: 15 October 2020

\section{References}

Abdollahzadeh J, Javadi A, Goltapeh EM, Zare R, Phillips AJL (2010) Phylogeny and morphology of four new species of Lasiodiplodia from Iran. Persoonia 25:1-10

Abdollahzadeh J, Zare R, Phillips AJL (2013) Phylogeny and taxonomy of Botryosphaeria and Neofusicoccum species in Iran, with description of Botryosphaeria scharifii sp. nov. Mycologia 105:210-220

Alves A, Correia A, Luque J, Phillips A (2004) Botryosphaeria corticola, sp. nov. on Quercus species, with notes and description of Botryosphaeria stevensii and its anamorph, Diplodia mutila. Mycologia 96:598-613

Alves A, Crous PW, Correia A, Phillips AJL (2008) Morphological and molecular data reveal cryptic speciation in Lasiodiplodia theobromae. Fungal Diversity 28:1-13

Ariyawansa HA, Hyde KD, Liu JK, Wu S-P, Liu ZY (2016) Additions to karst Fungi 1: Botryosphaeria minutispermatia sp. nov., from Guizhou Province, China. Phytotaxa 275:35-44

Begoude BAD (2010) Characterization of Botryosphaeriaceae and Cryphonectriaceae associated with Terminalia spp. in Africa. Dissertation, University of Pretoria

Begoude BAD, Slippers B, Wingfield MJ, Roux J (2010) Botryosphaeriaceae associated with Terminalia catappa in Cameroon, South Africa and Madagascar. Mycological Progress 9:101-123

Berraf-Tebbal A, Guereiro MA, Phillips AJL (2014) Phylogeny of Neofusicoccum species associated with grapevine trunk disease in Algeria, with description of Neofusicoccum algeriense sp. nov. Phytopathologia Mediterranea 53:416-427

Bickford D, Lohman DJ, Sodhi NS, Ng PKL, Meier R, Winker K, Ingram KK, Das I (2007) Cryptic species as a window on diversity and conservation. Trends in Ecology \& Evolution 22:148-155

Billones-Baaijens R, Savocchia S (2019) A review of Botryosphaeriaceae species associated with grapevine trunk diseases in Australia and New Zealand. Australasian Plant Pathology 48:3-18

Burgess TI, Andjic V, Hardy GESJ, Dell B, Xu D (2006a) First report of Phaeophleospora destructans in China. Journal of Tropical Forest Science 18: 144-146

Burgess TI, Barber PA, Hardy GESJ (2005) Botryosphaeria spp. associated with eucalypts in Western Australia, including the description of Fusicoccum macroclavatum sp. nov. Australasian Plant Pathology 34:557-567

Burgess TI, Barber PA, Mohali S, Pegg G, de Beer W, Wingfield MJ (2006b) Three new Lasiodiplodia spp. from the tropics, recognized based on DNA sequence comparisons and morphology. Mycologia 98:423-435

Carstensen GD, Venter SN, Wingfield MJ, Coutinho TA (2017) Two Ralstonia species associated with bacterial wilt of Eucalyptus. Plant Pathology 66:393-403

Chen SF, Gryzenhout M, Roux J, Xie YJ, Wingfield MJ, Zhou XD (2010) Identification and pathogenicity of Chrysoporthe cubensis on Eucalyptus and Syzygium spp. in South China. Plant Disease 94:1143-1150

Chen SF, Li GQ, Liu FF, Michailides TJ (2015) Novel species of Botryosphaeriaceae associated with shoot blight of pistachio. Mycologia 107:780-792

Chen SF, Liu QL, Li GQ, Wingfield MJ (2017) Quambalaria species associated with eucalypt diseases in southern China. Frontiers of Agricultural Science and Engineering 4:433-447

Chen SF, Morgan DP, Hasey JK, Anderson K, Michailides TJ (2014a) Phylogeny, morphology, distribution, and pathogenicity of Botryosphaeriaceae and Diaporthaceae from English walnut in California. Plant Disease 98:636-652

Chen SF, Morgan DP, Michailides TJ (2014b) Botryosphaeriaceae and Diaporthaceae associated with panicle and shoot blight of pistachio in California, USA. Fungal Diversity 67:157-179

Chen SF, Pavlic D, Roux J, Slippers B, Xie YJ, Wingfield MJ, Zhou XD (2011) Characterization of Botryosphaeriaceae from plantation-grown Eucalyptus species in South China. Plant Pathology 60:739-751

Chen SF, van Wyk M, Roux J, Wingfield MJ, Xie YJ, Zhou XD (2013) Taxonomy and pathogenicity of Ceratocystis species on Eucalyptus trees in South China, including C. chinaeucensis sp. nov. Fungal Diversity 58:267-279

Coppen JJW (ed) (2002) Eucalyptus: the genus Eucalyptus. Taylor \& Francis, London
Coutinho IBL, Freire FCO, Lima CS, Lima JS, Gonçalves FJT, Machado AR, Silva AMS Cardoso JE (2017) Diversity of genus Lasiodiplodia associated with perennial tropical fruit plants in northeastern Brazil. Plant Pathology 66:90-104

Crous PW, Groenewald JZ, Shivas RG, Edwards J, Seifert KA, Alfenas AC, Alfenas RF, Burgess TI, Carnegie AJ, Hardy GESJ, Hiscock N, Hüberli D, Jung T, LouisSeize G, Okada G, Pereira OL, Stukely MJC, Wang W, White GP, Young AJ, McTaggart AR, Pascoe IG, Porter IJ, Quaedvlieg W (2011) Fungal planet description sheets: 69-91. Persoonia 26:108-156

Crous PW, Groenewald JZ, Wingfield MJ, Phillips AJL (2007) Neofusicoccum mediterraneum. Fungal planet 19. CBS-KNAW Fungal Biodiversity Centre, Utrecht

Crous PW, Wingfield MJ, Guarro J, Cheewangkoon R, van der Bank M, Swart WJ, Stchigel AM, Cano-Lira JF, Roux J, Madrid H, Damm U, Wood AR, Shuttleworth LA, Hodges CS, Munster M, de Jesús Y-MM, Zúñiga-Estrada L, Cruywagen EM, de Hoog GS, Silvera C, Najafzadeh J, Davison EM, Davison PJN, Barrett MD, Barrett RL, Manamgoda DS, Minnis AM, Kleczewski NM, Flory SL, Castlebury LA, Clay K, Hyde KD, Maússe-Sitoe SND, Chen SF, Lechat C, Hairaud M, Lesage-Meessen L, Pawlowska J, Wilk M, Śliwińska-Wyrzychowska A, Mętrak M, Wrzosek M, Pavlic-Zupanc D, Maleme HM, Slippers B, Mac Cormack WP, Archuby DI, Grünwald NJ, Tellería MT, Dueñas M, Martín MP, Marincowitz S, de Beer ZW, Perez CA, Gené J, Marin-Felix Y, Groenewald JZ (2013) Fungal planet description sheets: 154-213. Persoonia 31:188-296

Cruywagen EM, Slippers B, Roux J, Wingfield MJ (2017) Phylogenetic species recognition and hybridisation in Lasiodiplodia: a case study on species from baobabs. Fungal Biology 121:420-436

Damm U, Crous PW, Fourie PH (2007) Botryosphaeriaceae as potential pathogens of Prunus species in South Africa, with descriptions of Diplodia africana and Lasiodiplodia plurivora sp. nov. Mycologia 99:664-680

Darriba D, Taboada GL, Doallo R, Posada D (2012) jModelTest 2: more models, new heuristics and parallel computing. Nature Methods 9:772

Denman S, Crous PW, Groenewald JZ, Slippers B, Wingfield BD, Wingfield MJ (2003) Circumscription of Botryosphaeria species associated with Proteaceae based on morphology and DNA sequence data. Mycologia 95:294-307

Denman S, Crous PW, Taylor JE, Kang J-C, Pascoe I, Wingfield MJ (2000) An overview of the taxonomic history of Botryosphaeria and a re-evaluation of ITS anamorphs based on morphology and ITS rDNA phylogeny. Studies in Mycology 45:129-140

Dissanayake AJ, Phillips AJL, Li XH, Hyde KD (2016) Botryosphaeriaceae: current status of genera and species. Mycosphere 7:1001-1073

Dissanayake AJ, Zhang W, Mei L, Chukeatirote E, Yan JY, Li XH, Hyde KD (2015) Lasiodiplodia pseudotheobromae causes pedicel and peduncle discolouration of grapes in China. Australasian Plant Disease Notes 10:21

Dou ZP, He W, Zhang Y (2017a) Lasiodiplodia chinensis, a new holomorphic species from China. Mycosphere 8:521-532

Dou ZP, He W, Zhang Y (2017b) Does morphology matter in taxonomy of Lasiodiplodia? An answer from Lasiodiplodia hyalina sp. nov. Mycosphere 8: 1014-1027

Fang XM, Zeng YL, Li ZJ, Li SJ, Zhu TH (2019) First report of Neofusicoccum parvum associated with blotch trunk disease of Koelreuteria paniculata in China. Plant Disease 103:1024

Farr DF, Elliott M, Rossman AY, Edmonds RL (2005) Fusicoccum arbuti sp. nov. causing cankers on Pacific madrone in western North America with notes on Fusicoccum dimidiatum, the correct name for Scytalidium dimidiatum and Nattrassia mangiferae. Mycologia 97:730-741

Guindon S, Dufayard J-F, Lefort V, Anisimova M, Hordijk W, Gascuel O (2010) New algorithms and methods to estimate maximum-likelihood phylogenies: assessing the performance of PhyML 3.0. Systematic Biology 59:307-321

Hillis DM, Bull JJ (1993) An empirical test of bootstrapping as a method for assessing confidence in phylogenetic analysis. Systematic Biology 42:182-192

IBM Corp (ed) (2011) IBM SPSS statistics for windows, version 20.0. IBM Corp, Armonk

Inderbitzin P, Bostock RM, Trouillas FP, Michailides TJ (2010) A six locus phylogeny reveals high species diversity in Botryosphaeriaceae from California almond. Mycologia 102:1350-1368

Jami F, Marincowitz S, Slippers B, Wingfield MJ (2018) New Botryosphaeriales on native red milkwood (Mimusops caffra). Australasian Plant Pathology 47:475-484

Jayawardena RS, Hyde KD, Jeewon R, Ghobad-Nejhad M, Wanasinghe DN, Liu N, Phillips AJL, Oliveira-Filho JRC, da Silva GA, Gibertoni TB, Abeywikrama P, Carris LM, Chethana KWT, Dissanayake AJ, Hongsanan S, Jayasiri SC, McTaggart AR, Perera RH, Phutthacharoen K, Savchenko KG, Shivas RG, Thongklang N, Dong W, Wei D, Wijayawardena NN, Kang JC (2019a) One 
stop shop II: taxonomic update with molecular phylogeny for important phytopathogenic genera: 26-50 (2019). Fungal Diversity 94:41-129

Jayawardena RS, Hyde KD, McKenzie EHC, Jeewon R, Phillips AJL, Perera RH, de Silva NI, Maharachchikumburua SSN, Samarakoon MC, Ekanayake AH, Tennakoon DS, Dissanayake AJ, Norphanphoun C, Lin C, Manawasinghe IS, Tian Q, Brahmanage R, Chomnunti P, Hongsanan S, Jayasiri SC, Halleen F, Bhunjun CS, Karunarathna A, Wang Y (2019b) One stop shop III: taxonomic update with molecular phylogeny for important phytopathogenic genera: 51-75 (2019). Fungal Diversity 98:77-160

Jiang N, Wang X, Liang Y, Tian C (2018) Lasiodiplodia cinnamomi sp. nov. from Cinnamomum camphora in China. Mycotaxon 133:249-259

Katoh K, Standley DM (2013) MAFFT multiple sequence alignment software version 7: improvements in performance and usability. Molecular Biology and Evolution 30:772-780

Li GQ, Arnold RJ, Liu FF, Li JQ, Chen SF (2015) Identification and pathogenicity of Lasiodiplodia species from Eucalyptus urophylla $\times$ grandis, Polyscias balfouriana and Bougainvillea spectabilis in southern China. Journal of Phytopathology 163:956-967

Li GQ, Liu FF, Li JQ, Liu QL, Chen SF (2018) Botryosphaeriaceae from Eucalyptus plantations and adjacent plants in China. Persoonia 40:63-95

Li JQ, Wingfield MJ, Liu QL, Barnes I, Roux J, Lombard L, Crous PW, Chen SF (2017) Calonectria species isolated from Eucalyptus plantations and nurseries in South China. IMA Fungus 8:259-286

Li SB, Li JZ, Li SC, Lu ZH, Wang JH, Zhang H (2010) First report of Neofusicoccum parvum causing dieback disease of Chinese weeping cypress in China. Plant Disease 94:641

Linaldeddu BT, Deidda A, Scanu B, Franceschini A, Serra S, Berraf-Tebbal A, Zouaoui Boutiti M, Ben Jamâa ML, Phillips AJL (2015) Diversity of Botryosphaeriaceae species associated with grapevine and other woody hosts in Italy, Algeria and Tunisia, with descriptions of Lasiodiplodia exigua and Lasiodiplodia mediterranea sp. nov. Fungal Diversity 71:201-214

Liu JK, Phookamsak R, Doilom M, Wikee S, Li YM, Ariyawansha H, Boonmee S, Chomnunti P, Dai DQ, Bhat JD, Romero Al, Zhuang WY, Monkai J, Gareth Jones EB, Chukeatirote E, Ko TWK, Zhao YC, Wang Y, Hyde KD (2012) Towards a natural classification of Botryosphaeriales. Fungal Diversity 57:149-210

Liu QL, Li GQ, Li JQ, Chen SF (2016) Botrytis eucalypti, a novel species isolated from diseased Eucalyptus seedlings in South China. Mycological Progress 15:1057-1079

Liu YX, Shi YP, Deng YY, Li LL, Dai LM, Cai ZY (2017) First report of Neofusicoccum parvum causing rubber tree leaf spot in China. Plant Disease 101:1545

Lombard L, Zhou XD, Crous PW, Wingfield BD, Wingfield MJ (2010) Calonectria species associated with cutting rot of Eucalyptus. Persoonia 24:1-11

Lopes A, Phillips AJL, Alves A (2017) Mating type genes in the genus Neofusicoccum: mating strategies and usefulness in species delimitation. Fungal Biology 121:394-404

Machado AR, Pinho DB, Pereira OL (2014) Phylogeny, identification and pathogenicity of the Botryosphaeriaceae associated with collar and root rot of the biofuel plant Jatropha curcas in Brazil, with a description of new species of Lasiodiplodia. Fungal Diversity 67:231-247

Manawasinghe IS, Phillips AJL, Hyde KD, Chethana KWT, Zhang W, Zhao WS, Yan JY, Li XH (2016) Mycosphere essays 14: assessing the aggressiveness of plant pathogenic Botryosphaeriaceae. Mycosphere 7: 883-892

Marin-Felix Y, Groenewald JZ, Cai L, Chen Q, Marincowitz S, Barnes I, Bensch K, Braun U, Camporesi E, Damm U, de Beer ZW, Dissanayake A, Edwards J, Giraldo A, Hernández-Restrepo M, Hyde KD, Jayawardena RS, Lombard L, Luangsa-ard J, McTaggart AR, Rossman AY, Sandoval-Denis M, Shen M, Shivas RG, Tan YP, van der Linde EJ, Wingfield MJ, Wood AR, Zhang JQ, Zhang Y, Crous PW (2017) Genera of phytopathogenic fungi: GOPHY 1. Studies in Mycology 86:99-216

Marques MW, Lima NB, de Morais MA, Michereff SJ, Phillips AJL, Câmara MPS (2013) Botryosphaeria, Neofusicoccum, Neoscytalidium and Pseudofusicoccum species associated with mango in Brazil. Fungal Diversity 61:195-208

Mehl J, Wingfield M, Roux J, Slippers B (2017) Invasive everywhere? Phylogeographic analysis of the globally distributed tree pathogen Lasiodiplodia theobromae. Forests 8:145

Mohali S, Slippers B, Wingfield MJ (2006) Two new Fusicoccum species from Acacia and Eucalyptus in Venezuela, based on morphology and DNA sequence data. Mycological Research 110:405-413
Mohali SR, Slippers B, Wingfield MJ (2009) Pathogenicity of seven species of the Botryosphaeriaceae on Eucalyptus clones in Venezuela. Australasian Plant Pathology 38:135-140

NCBI Nucleotide Database. https://www.ncbi.nlm.nih.gov/nuccore/?term= Lasiodiplodia+pseudotheobromae+spacer. Accessed 3rd Dec 2019

Netto MSB, Assunção IP, Lima GSA, Marques MW, Lima WG, Monteiro JHA, de Queiroz BV, Michereff SJ, Phillips AJL, Câmara MPS (2014) Species of Lasiodiplodia associated with papaya stem-end rot in Brazil. Fungal Diversity 67:127-141

Netto MSB, Lima WG, Correia KC, da Silva CFB, Thon M, Martins RB, Miller RNG, Michereff SJ, Câmara MPS (2017) Analysis of phylogeny, distribution, and pathogenicity of Botryosphaeriaceae species associated with gummosis of Anacardium in Brazil, with a new species of Lasiodiplodia. Fungal Biology 121 : 437-451

Old KM, Wingfield MJ, YuanZQ (ed) (2003) A manual of diseases of eucalypts in South-East Asia. Centre for International Forestry Research, Bogor

Osorio JA, Crous CJ, de Beer ZW, Wingfield MJ, Roux J (2017) Endophytic Botryosphaeriaceae, including five new species, associated with mangrove trees in South Africa. Fungal Biology 121:361-393

Pavlic D, Slippers B, Coutinho TA, Gryzenhout M, Wingfield MJ (2004) Lasiodiplodia gonubiensis sp. nov., a new Botryosphaeria anamorph from native Syzygium cordatum in South Africa. Studies in Mycology 50:313-322

Pavlic D, Slippers B, Coutinho TA, Wingfield MJ (2009a) Molecular and phenotypic characterization of three phylogenetic species discovered within the Neofusicoccum parvum / N. ribis complex. Mycologia 101:636-647

Pavlic D, Slippers B, Coutinho TA, Wingfield MJ (2009b) Multiple gene genealogies and phenotypic data reveal cryptic species of the Botryosphaeriaceae: a case study on the Neofusicoccum parvum / N. ribis complex. Molecular Phylogenetics and Evolution 51:259-268

Pavlic D, Wingfield MJ, Barber P, Slippers B, Hardy GESJ, Burgess TI (2008) Seven new species of the Botryosphaeriaceae from baobab and other native trees in Western Australia. Mycologia 100:851-866

Pérez CA, Wingfield MJ, Slippers B, Altier NA, Blanchette RA (2010) Endophytic and canker-associated Botryosphaeriaceae occurring on non-native Eucalyptus and native Myrtaceae trees in Uruguay. Fungal Diversity 41:53-69

Phillips A, Alves A, Correia A, Luque J (2005) Two new species of Botryosphaeira with brown, 1-septate ascospores and Dothiorella anamorphs. Mycologia 97: 513-529

Phillips AJL, Alves A, Abdollahzadeh J, Slippers B, Wingfield MJ, Groenewald JZ, Crous PW (2013) The Botryosphaeriaceae: genera and species known from culture. Studies in Mycology 76:51-167

Phillips AJL, Alves A, Pennycook SR, Johnston PR, Ramaley A, Akulov A, Crous PW (2008) Resolving the phylogenetic and taxonomic status of dark-spored teleomorph genera in the Botryosphaeriaceae. Persoonia 21: 29-55

Phillips AJL, Hyde KD, Alves A, Liu JK (2019) Families in Botryosphaeriales: a phylogenetic, morphological and evolutionary perspective. Fungal Diversity $94: 1-22$

Phillips AJL, Oudemans PV, Correia A (2006) Characterisation and epitypification of Botryosphaeria corticis, the cause of blueberry cane canker. Fungal Diversity 21:141-155

Prasher IB, Singh G (2014) Lasiodiplodia indica - a new species of coelomycetous mitosporic fungus from India. KAVAKA 43:64-69

Qi SX (ed) (2002) Eucalyptus in China. China Forestry Publishing House, Beijing (in Chinese)

Rayner RW (ed) (1970) A mycological colour chart. Commonwealth Mycological Institute, Surrey

Rodríguez-Gálvez E, Guerrero P, Barradas C, Crous PW, Alves A (2017) Phylogeny and pathogenicity of Lasiodiplodia species associated with dieback of mango in Peru. Fungal Biology 121:452-465

Sakalidis ML, Hardy GESJ, Burgess TI (2011) Use of the genealogical sorting index (GSI) to delineate species boundaries in the Neofusicoccum parvumNeofusicoccum ribis species complex. Molecular Phylogenetics and Evolution 60:333-344

Sakalidis ML, Slippers B, Wingfield BD, Hardy GESJ, Burgess TI (2013) The challenge of understanding the origin, pathways and extent of fungal invasions: global populations of the Neofusicoccum parvum-N. ribis species complex. Diversity and Distributions 19:873-883

SAS Institute Inc (ed) (2011) SAS $9.3^{\circledR}$ system options: reference, Second edn. SAS Institute Inc, Cary 
Seifert KA, Rossman AY (2010) How to describe a new fungal species. IMA Fungus 1:109-116

Slippers B, Boissin E, Phillips AJL, Groenewald JZ, Lombard L, Wingfield MJ, Postma A, Burgess T, Crous PW (2013) Phylogenetic lineages in the Botryosphaeriales: a systematic and evolutionary framework. Studies in Mycology 76:31-49

Slippers B, Crous PW, Denman S, Coutinho TA, Wingfield BD, Wingfield MJ (2004a) Combined multiple gene genealogies and phenotypic characters differentiate several species previously identified as Botryosphaeria dothidea. Mycologia 96:83-101

Slippers B, Crous PW, Jami F, Groenewald JZ, Wingfield MJ (2017) Diversity in the Botryosphaeriales: looking back, looking forward. Fungal Biology 121:307-321

Slippers B, Fourie G, Crous PW, Coutinho TA, Wingfield BD, Carnegie J, Wingfield MJ (2004b) Speciation and distribution of Botryosphaeria spp. on native and introduced Eucalyptus trees in Australia and South Africa. Studies in Mycology 50:343-358

Slippers B, Fourie G, Crous PW, Coutinho TA, Wingfield BD, Wingfield MJ (2004C) Multiple gene sequences delimit Botryosphaeria australis sp. nov. from $B$. lutea. Mycologia 96:1030-1041

Slippers B, Johnson Gl, Crous PW, Coutinho TA, Wingfield BD, Wingfield MJ (2005) Phylogenetic and morphological re-evaluation of the Botryosphaeria species causing diseases of Mangifera indica. Mycologia 97:99-110

Slippers B, Roux J, Wingfield MJ, van der Walt FJJ, Jami F, Mehl JWM, Marais GJ (2014) Confronting the constraints of morphological taxonomy in the Botryosphaeriales. Persoonia 33:155-168

Slippers B, Wingfield MJ (2007) Botryosphaeriaceae as endophytes and latent pathogens of woody plants: diversity, ecology and impact. Fungal Biology Reviews 21:90-106

Smith H, Crous PW, Wingfield MJ, Coutinho TA, Wingfield BD (2001) Botryosphaeria eucalyptorum sp. nov., a new species in the B. dothideacomplex on Eucalyptus in South Africa. Mycologia 93:277

Smith H, Wingfield MJ, Crous PW, Coutinho TA (1996) Sphaeropsis sapinea and Botryosphaeria dothidea endophytic in Pinus spp. and Eucalyptus spp. in South Africa. South African Journal of Botany 62:86-88

Summerell BA, Groenewald JZ, Carnegie AJ, Summerbell RC, Crous PW (2006) Eucalyptus microfungi known from culture. 2. Alysidiella, Fusculina and Phlogicylindrium genera nova, with notes on some other poorly known taxa. Fungal Diversity 23:323-350

Swofford DL (2002) PAUP*. Phylogenetic analysis using parsimony (* and other methods). Sinauer associates, Sunderland

Tamura K, Stecher G, Peterson D, Filipski A, Kumar S (2013) MEGA6: molecular evolutionary genetics analysis version 6.0. Molecular Biology and Evolution 30:2725-2729

Taylor K, Barber PA, Hardy GE SJ, Burgess TI (2009) Botryosphaeriaceae from tuart (Eucalyptus gomphocephala) woodland, including descriptions of four new species. Mycological Research 113:337-353

Tennakoon DS, Phillips AJL, Phookamsak R, Ariyawansa HA, Bahkali AH, Hyde KD (2016) Sexual morph of Lasiodiplodia pseudotheobromae (Botryosphaeriaceae, Botryosphaeriales, Dothideomycetes) from China. Mycosphere 7:990-1000

Tibpromma S, Hyde KD, McKenzie EHC, Bhat DJ, Phillips AJL, Wanasinghe DN, Samarakoon MC, Jayawardena RS, Dissanayake AJ, Tennakoon DS, Doilom M, Phookamsak R, Tang AMC, Xu J, Mortimer PE, Promputtha I, Maharachchikumbura SSN, Khan S, Karunarathna SC (2018) Fungal diversity notes 840-928: micro-fungi associated with Pandanaceae. Fungal Diversity 93:1-160

Trakunyingcharoen T, Lombard L, Groenewald JZ, Cheewangkoon R, To-anun C, Crous PW (2015) Caulicolous Botryosphaeriales from Thailand. Persoonia 34: 87-99

Urbez-Torres JR, Peduto F, Striegler RK, Urrea-Romero KE, Rupe JC, Cartwright RD, Gubler WD (2012) Characterization of fungal pathogens associated with grapevine trunk diseases in Arkansas and Missouri. Fungal Diversity 52:169-189

van Burik JAH, Schreckhise RW, White TC, Bowden RA, Myerson D (1998) Comparison of six extraction techniques for isolation of DNA from filamentous fungi. Medical Mycology 36:299-303

van Niekerk JM, Crous PW, Groenewald JZ, Fourie PH, Halleen F (2004) DNA phylogeny, morphology and pathogenicity of Botryosphaeria species on grapevines. Mycologia 96:781-798

Velásquez AC, Castroverde CDM, He SY (2018) Plant and pathogen warfare under changing climate conditions. Current Biology 28:R619-R634
Wang W, Liu QL, Li GQ, Liu FF, Chen SF (2018) Phylogeny and pathogenicity of Celoporthe species from plantation Eucalyptus in southern China. Plant Disease 102:1915-1927

Wu RH, Zhang Y, Li ZP (2019) First report of leaf spot on rubber tree caused by Lasiodiplodia pseudotheobromae in China. Plant Disease 103:766

Xie YJ, Arnold RJ, Wu ZH, Chen SF, Du AP, Luo JZ (2017) Advances in eucalypt research in China. Frontiers of Agricultural Science \& Engineering 4:380-390

Xu C, Wang C, Ju L, Zhang R, Biggs AR, Tanaka E, Li B, Sun G (2015) Multiple locus genealogies and phenotypic characters reappraise the causal agents of apple ring rot in China. Fungal Diversity 71:215-231

Yang T, Groenewald JZ, Cheewangkoon R, Jami F, Abdollahzadeh J, Lombard L, Crous PW (2017) Families, genera, and species of Botryosphaeriales. Fungal Biology 121:322-346

Ye W (ed) (2017) Lanscape and geography of YunNan Province. Science Press, Beijing (in Chinese)

Yu L, Chen XL, Gao LL, Chen HR, Huang Q (2009) First report of Botryosphaeria dothidea causing canker and shoot blight of Eucalyptus in China. Plant Disease 93:764

Yu Z, Tang G, Peng S, Chen H, Zhai M (2015) Neofusicoccum parvum causing canker of seedlings of Juglans regia in China. Journal of Forestry Research 26: 1019-1024

Zhai L, Zhang M (2019) First report of Neofusicoccum parvum causing fruit rot on Eriobotrya japonica in China. Plant Disease 103:2125

Zhang M, Lin S, He W, Zhang Y (2017) Three species of Neofusicoccum (Botryosphaeriaceae, Botryosphaeriales) associated with woody plants from southern China. Mycosphere 8:797-808

Zhao JP, Lu Q, Liang J, Decock C, Zhang XY (2010) Lasiodiplodia pseudotheobromae, a new record of pathogenic fungus from some subtropical and tropical trees in southern China. Cryptogamie Mycologie 31: $431-439$

Zhou XD, de Beer ZW, Xie YJ, Pegg GS, Wingfield MJ (2007) DNA-based identification of Quambalaria pitereka causing severe leaf blight of Corymbia citriodora in China. Fungal Diversity 25:245-254

Zhou Y, Dou Z, He W, Zhang X, Zhang Y (2016) Botryosphaeria sinensia sp. nov., a new species from China. Phytotaxa 245:43-50

Zhou YP, Zhang M, Dou ZP, Zhang Y (2017) Botryosphaeria rosaceae sp. nov. and B. ramosa, new botryosphaeriaceous taxa from China. Mycosphere 8:162-171

\section{Publisher's Note}

Springer Nature remains neutral with regard to jurisdictional claims in published maps and institutional affiliations.

Ready to submit your research? Choose BMC and benefit from:

- fast, convenient online submission

- thorough peer review by experienced researchers in your field

- rapid publication on acceptance

- support for research data, including large and complex data types

- gold Open Access which fosters wider collaboration and increased citations

- maximum visibility for your research: over $100 \mathrm{M}$ website views per year

At $\mathrm{BMC}$, research is always in progress.

Learn more biomedcentral.com/submissions 